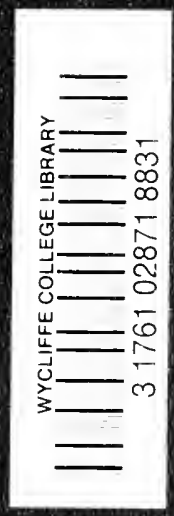

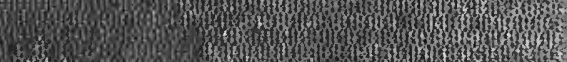
HW How

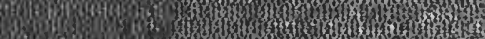

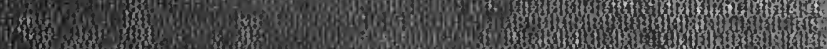
3row

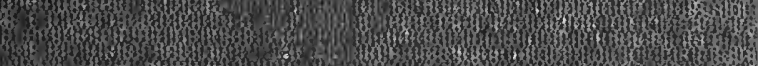
How 3 (3)

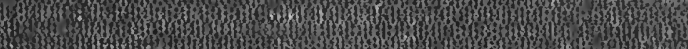

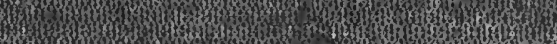
Shy

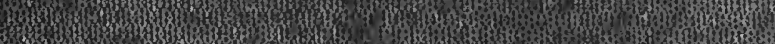
13. fom thith Q74)

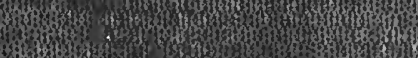

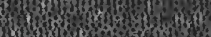
Q H. Ixim Ald OH H.t.

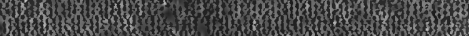




\title{
AUTHORITY IN RELIGION
}

\author{
BY \\ REv. J. $\underset{\text { CUPAR-FIFE }}{\text { H. LECKIE }}$
}

CURRE hic vel ibi: non invenies quietem, nisi in hunili subjectione sub praelati regimine.Thomas à Kempis.

Vos vocatis me magistrum ac dominum: et bene dicitis; sum etenim.-ST. JoHN xiii. $\mathbf{1 3}_{3}$

Edinburgh : T. \& T. CLARK, 38 George St 1280 I 909 
Printed by

Morrison \& Gibb Limited,

FOR

T. \& T. CLARK, EDINBURGH.

LONDON: SIMPKIN, MARSHALI, HAMILTON, KENT, AND CO, LIMITED NEW YORK : CHARLES SCRIBNER'S SONS.

$$
4518.2027
$$




\section{PREF ACE}

THE purpose of this book is not so much dogmatic as suggestive. It does, however, endeavour to present a systematic treatment of its theme. Its argument is mediating and conservative. It attempts to show that the theory which traces Authority in Re- ligion to the direct, universal communion of God with man involves recognition of the great 'objective' forms in which Authority presents itself as a fact of history and of experience.

Many great books have been written on Authority, in English, German, and (especially perhaps) in French. But there may be room for a short treatise, introductory to the subject and seeking to combine brevity with some degree of comprehensiveness and system.

It may be objected to the plan of this book that it does not contemplate any separate treatment of the Authority of the Bible. But, from the point of view represented here, the problem of the Scriptures 
does not seem to involve any special difficulties. The enduring claim of our Sacred Writings to be held in peculiar reverence is that they are the Record of Revelation and the classical Literature of Faith. Their sanction is the divine Voices whose message they contain.

I have to thank the Editor of the London Quarterly Review for permission to use an article of mine which appeared in that Journal. It forms the substance of Chapter V. on "The Theoretic Source and Organ of Authority."

My cordial thanks for encouragement and help are due to the Rev. D. W. Forrest, D.D., and the Rev. Prof. Cairns, D.D. Principal Iverach showed me great kindness in allowing me the privilege of seeing the proofs of his article on "Authority" in Hastings' Encyclopadia of Religion and Ethics.

I am indebted to the Rev. James P. Gibson for very careful reading of my MS.

CUPAR, A'ugust igog.

J. H. L. 


\section{CONTEN'TS}

CHAP.

FACT OF AUTHORITY

II. The Fact of Freedom . . 12

III. The Problem of Authority a 22

IV. AUthority and Infallibility . 56

V. The Theoretic Source and Organ of AUTHORITY . . . . . 68

VI. The Authority of the Prophets-The

ARISTOCRATS . . . . IIO

VII. The AUthority OF THE ChURCH-ThE

Christian Democracy • $\quad$ • $\quad$. 129

VIII. The Authority of Jesus Christ-the LORD . $\quad . \quad$. . . $\quad$ r 78

IX. Concluding Note . . . . 220

INDEX $\quad \cdot \quad+\quad \quad \cdot \quad+233$ 



\section{OUTLINE OF ARGUMEN'T}

Chapter I'. Defines Authority, and asserts its reality, and its abiding necessity, in Life and Religion.

Chapter II. States, on the other hand, the case for Freedom and Individualism as essential elements in Thought and Faith.

Chapter III. States the Problem of Authority. In the first place, the difficulty of reconciling the opposing claims of Authority and Freedom is considered. Secondly, the argument, passing from the question of Authority as opposed to Freedom, proceeds to consider the perplexities presented by the nature of Authority in itself, as illustrated in the religious history of the past, as well as in the present position of theological thought.

Chapter IV. Distinguishes between Authority and Infallibility; and discusses the nature of Religious Certainty.

Chapter V. Concludes these preliminary discussions; and goes on to state a theory of Authority, as to its ideal Source and Organ. The "Source" is held to be God Himself, and the "Organ" the Soul in communion with God-This position is explained and defended, and an outline given of its application to the facts of Authority, as it is embodied in the Prophets, the Church and the Christ.

Chapters VI. VII. and VIII. Expand, apply and illustrate the contentions of Chapter V. 
Chapter VI. Shows the authority of the Spiritual Aristocrats (the Prophets) to rest on their being specially endowed with a grace not wholly denied to any.

Chapter VII. Maintains the authority of the Religious Democracy (the Church) to be legitimate, inasmuch as it expresses the Witness of the Corporate Conscience-the common testimony of believing minds throughout many generations.-Objections to this are considered-The authority of the Church is shown to be, essentially and primarily, a religious one; but it is admitted to be also, in a secondary way, dogmatic. In conclusion there is urged the importance of asserting this form of Authority at the present time.

Chapter VIII. Applies the theory of this book to the Authority of Christ, the Lord. The acceptance of that Authority is shown to be the necessary crown and fulfilment of the theory maintained. This is illustrated in relation to the three elements in the Lordship of Christ, ( $\mathbf{r}$ ) His prophetic Office, (2) His Consciousness of Himself, (3) the Testimony of the Church. Finally, the various dogmatic symbols of the historic faith as to Jesus are considered.

Chapter IX. (a) Recapitulates; ( $b$ ) suggests practical Inferences as to relations between Authority and the Individual. 


\section{AUTHORITY IN RELIGION}

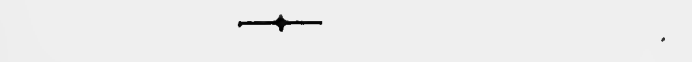

CHAPTER I

THE FACT OF AUTHORITY

M. Auguste Sabatier defines authority as " the right of the species over the individual." 1 But this definition, however sufficient as applied to the facts of social life, is too narrow to embrace the phenomena of religion. It altogether ignores, for instance, the power wielded by the individual over the multitude through the voice of the prophet and the written word. It may describe the right of the Church and of many-tongued tradition : but it leaves entirely unexplained the authority of Moses, of Buddha, of Mohammed, of Christ. Perhaps a more adequate definition might be stated in this way:-Authority is a power that constrains to belief and action, ${ }^{1}$ Religions of Authority and the Religion of the Spirit, p. 4 . I 
and is recognised by the individual as existing independently of his own thought or will. More shortly we may describe authority as a power, not self-produced, which rules belief or conduct. Some such definition may be found to embrace the facts with which it deals. It includes the laws of the State and society, which are certainly imposed on their subjects from without. It recognises the imperative of the moral law ; since we cannot, by any theory of ethics, attribute the origin of this law to the will that obeys it. Finally, it takes into account all the forms of religious authority, whether of Church or Prophet or Holy Book, or Mystical experience: for all these are recognised by the devout mind as neither self-discovered nor self-produced, and it is ever the confession of the Saints that they do not find the truth but the truth them, that the things they believe are not of the will of man but of God.

But whatever definition of authority we accept, there can be no doubt that the thing itself is a persistent fact of life. Authority is an essential element in all the things of beauty and all the things of power. In social and political matters its necessity is universally confessed. Every society has a "supreme rule" which is law, and a "subordinate 
standard" which is convention. Theories differ as to the ideal form of government, but not as to the reality and value of that power of the species over the individual which every government represents. Philosophy also in all its history bears witness to authority, since thought has always advanced, according to law, and as much through discipleship as through freedom. Every master has been first a scholar, and of all his work the lesser part has ever been his own. Natural science, again, is but the progressive unveiling of a

- Kingdom of Order, and lives by a faithful submission to rule. Art, too, has the same testimony to bear. Every kind of handicraft is compelled to work within the limits prescribed for it by the material which it shapes -wood or stone or iron or gold; while in every higher art, and in literature most of all, great works owe their beauty and strength not less to obedience than to discovery. ${ }^{1}$

"The kings of thought with august submission Bow to the laws that out-last us all." 2

When we say that artists and men of genius are men of vision, we mean that they have power to see something which, whenever it is seen, lays on them its law and compels them

${ }^{1}$ Cf. Ruskin's Lamp of Obedience. $\quad 2$ William Watson. 
to its will. If we have to say of the masterworker that in proportion to his greatness he is free, we have to say also that in proportion to his greatness he is bound. The vision of beauty constrained the Greek sculptor as the vision of Christ constrained Paul. Wherever, in short, you find in human things beauty and greatness, there you find order and submission. It is true in every realm of thought and achievement that he who would rule must obey, that reverence is the secret of reverend, that he who would save his life must lose it. ${ }^{1}$

But if authority is thus a permanent fact of life, it is in a special sense a permanent fact of religion. It presents itself to the student of history. as a persistent attribute of every faith. Whether one regards it, in any given manifestation, as a blessing or an evil, as a degenerate growth or the outcome of vital principle, it is plainly to be reckoned with as a power that exists. It is as clearly a datum of inductive theology as it is of social science. It is to be explained, but not explained away -to be studied, analysed, limited, adjusted, in its relations to other factors in religious life, but not by any means to be ignored.

That this is so we need not stop to prove.

${ }^{1}$ For the noblest of all the expositions of Authority, see Plato's Crito. 
The truth is written large for every one to read. Every historic faith says to its disciples, "Ye call me Master and Lord: and ye say well, for so I am." The Hindu religion, with its sacred books, its priesthood and mysteries and incarnations : Buddhism, hailing Sakya Muni as "the Lord Buddha": Confucianism, with its profound reverence for the writings of its founder, and its patriarchal system of graduated despotism : the Mohammedan faith, receiving the Koran as the infallible oracle of God, in every word and line inspired,-all these have - for their common feature authority. In none of them can the right of private judgment be properly said to exist. They exact at their best the obedience of a child, at their worst the submission of a slave. Nor do we find it radically otherwise when we consider the records of Christianity. Authority baptized into the Christian name experiences regeneration but remains Authority still. The Roman theology teaches the infallibility of the Church and its divine right to rule without question in all the domains of faith and morals. "The Church," says the ablest modern exponent of Roman theory, "cannot fail in the pure presentation of the word ... is infallible." 1 Orthodox Protestantism accepts

1 Moehler, Symbolism, p. $26 \mathrm{I}$. 
the principle of Authority as sincerely as does the Roman system, though it hesitates and wavers when it is asked to define that principle. Among Reformed theologians, some have affirmed the literal infallibility of the Bible, some have found Authority in the Scripture interpreted by the Holy Spirit through the Christian conscience, some have taught the duty of submission to the general voice of the Christian Society; while others have declared a doctrine whose formula seems to be this:Scripture plus Church plus Conscience, minus the deductions of Reason and Science equals Authority. A general survey of Protestant theology yields the result that while the form and theory of Authority may be in doubt, the fact of it is clearly seen and the need of it confessed.

All organised reformed Churches, also, bear by their very constitution the same witness. Episcopacy and Presbyterianism, as highlydeveloped Ecclesiastical Forms, imply a very advanced view as to the right of the Church to teach and govern. Bishops rule by right divine: and Presbyterian Courts act by "Authority of the Lord Jesus Christ, the King and Head." The Lutheran and Reformed Churches of 'the Continent' are not less distinct in their claims. Independency, 
renouncing obedience to councils or high officers, exalts to lofty heights of spiritual power the individual Christian society and its appointed courts. Unitarians are commonly regarded as carrying to the furthest point the doctrine of private judgment and the free conscience: yet Unitarians have organised congregations and forms of Common Prayer, both of which logically involve the denial of a coherent individualism. Even Quakers find the doctrine of the Inner Light consistent with a whole-hearted acceptance of the Lordship of Jesus. It is a Quaker who sings :

"O Lord and Master of us all."

In short, the ecclesiastical, like the theological, forms of Protestant Christianity bear witness to Authority. Wherever you have Sacraments or a common Worship and Confession, wherever you have a claim made to the power of the keys by Baptism and Ex-communication, there you have a more or less complete form of the power that constrains to belief and action, and is recognised by him who obeys it as neither self-discovered nor self-evolved.

But if we find the fact of Authority in all theologies and Churches, we discover it also in the individual experience of the devout man. The average member of all communions is 
dependent for the main part of his faith and for the forms of his religious life on the tradition of his fathers. The pious Roman has been from his childhood a member of the mystical Church of Christ, the living Body of the Redeemer. Her creeds have been part of his mind since ever he began to know : her sacraments have nourished, cleansed and comforted him; by her appointed forms he has expressed his aspirations, hopes, penitence and fear; her hand laid hold of him in baptism, has touched and supported him at every point and crisis of his pilgrimage, and in the end will surely commit him to the safe keeping of the Eternal. The Protestant Christian, too, though he differ from his Roman brother in a hundred ways, yet believes in substance what he learned in his youth. He has not been able to test and try the doctrines of his faith. Whatever his theoretical freedom, whatever his minor individualisms may be, he yet believes in the main as he has been taught. His guide is commonly just the Scripture interpreted by his Church. $\mathrm{He}$ is, on the whole, dependent on worship and sacrament and expert teaching for the substance of his religious thought and practice. Even his heresies and speculations bear a very small proportion to the whole of his belief; even when he is a scholar and a 
thinker, he has received from tradition far more than he gives; even when he declares his 'spiritual independence' he commonly uses it very little. His "ex-tempore" prayers were old before he was born. The words of his worship, the daily bread of his devotion, he receives from the hand of Authority.

Authority, then, is a "note" of all worthy things : but especially of religion, because religion is informed by instincts and emotions that exalt the ideas of discipleship, obedience, dependence, humility. There is an impulse in all faiths towards self-surrender, enthusiasm, generous abandonment. The devout spirit is restless until it rests in a strength and a truth that are protection and home: but the sense of protection and home is impossible without the sense of Authority. Whatever protects governs, whatever gives rest takes charge. The greatest of all the Masters of Faith spoke of the Shepherd and the sheep, and had much to say of the child-like spirit of which is the Kingdom of Heaven. It may be doubted whether due weight has ever been given to this element in the doctrine of the New Testament, and especially in the whole tone and temper, as well as in the direct instruction, of Jesus. Throughout the parabolic teaching of our Lord there is found a very deep sense 
of the dependence of the average man on spiritual teachers and guides. The same conviction is implied in His stern judgment of incompetent and unfaithful leaders, in the importance $\mathrm{He}$ attached to personal trust in Himself, in $\mathrm{His}$ whole conception of the Kingdom of God, and, most movingly, in the compassion He felt for the multitude because they were a shepherdless flock. As the secret of His own blessedness lay in His unbroken assent to the will of the Highest, so $\mathrm{He}$ was assured that the secret of peace and of power for every man was the loyal acceptance of a spiritual Master, was the Yea and Amen of the soul. Milton was a true interpreter of faith when he said,

"Henceforth I learn that to obey is best."

You cannot take this element out of any religion without destroying it altogether. You cannot refuse obedience and retain adoration, you cannot deny the Son and confess the Father. It is impossible to enter the Holy Place except by the door of "august submission." This is true of every faith, and most of all of Christianity. Christianity is especially an historical religion, and, as such, carries the principle of Authority in its peculiar genius. Wherever history is, Authority is. 
A tree must recognise its root, every leaf and twig must acknowledge dependence: and, in like manner, a religion that has its source in certain facts and experiences can never cease to yield homage to those things in which it had its birth. A faith that stretches back through the linked generations to a Person and a Life can never be free, or wish to be free, of that Person and that Life. "Thou bearest not the root, but the root thee." 


\section{CHAPTER II}

\section{THE FACT OF FREEDOM}

While we are thus compelled to recognise the fact of Authority in religion, we are constrained also to admit the fact of Freedom. The Church exists, but so does the individual conscience. Tradition is a great power, but so also is discovery. Faith has in it the instinct of submission, but it also quickens heart and mind to energy of action, to stern assertion and sometimes to denial. The Prophets and Apostles are authorities now, but they were rebels and reformers once. The truths that command a ready and thoughtless assent today were once heard with awe and wonder in lonely hearts. The light that is for us the broad unquestionable noon was hailed in the hour of its solemn rising with marvelling welcome and a joy that was full of fear. Athanasius, whose name is now the type of Catholic Orthodoxy, was once Athanasius contra mundum. Christ with authority op- 
posed Authority; and the Cross itself is the symbol of combined submission and revolt.

It would be a profitless thing to inquire whether religion owes its greater debt to Authority or to Freedom; for the answer returned to such a question must always depend, in part at least, on the individual training and temperament of the man who gives it. Every one is by nature a Roman or a Protestant, a conformist or a rebel, and each will magnify that tendency to which his life belongs. Individual judgment, also, as to the comparative value of liberty and order, will change with changing moods and hours. Ruskin remarks that St. Francis, one of whose rules was Obedience, began his career by disobeying his father. Luther himself had times of regret when he thought that perhaps after all you needed the Pope to fight the Devil in such a world as this. The Roman apologist, on the other hand, as he considers the state of the world and the Church when Protestantism arose, will almost admit the justice of that great Separation. $^{1}$ The hardiest recusant will sometimes long to renounce the "reason's

1 Döllinger, Preface to Kirche und Kirchen, p. I7: "We do not refuse to admit that the great separation, and the storms and sufferings connected with it, were an awful judgment upon Catholic Christendom, which clergy and laity had but too well deserved." 
colder part," to submit and worship and have peace : while the most devout and trustful mind will often know a sudden fear; a hand unseen will 'sow disquietude' upon its pleasant fields. It was Newman who said: "If I looked into a mirror and did not see my face I would have the sort of feeling which actually comes to me when I look into the busy toiling world, and see no reflexion of its Creator." And it was Clough, the individualist and sceptic, who wrote this tender and pathetic defence of Authority :

"Old things need not be therefore true:

$O$ brother men, nor yet the new.

The souls of now two thousand years

Have laid up here their toils and fears

And all the earnings of their pain.

Ah yet, consider it again."

Thus, all judgment as to the comparative value of authority and freedom in faith will always be influenced by individual bias, mood and experience. No such judgment need be attempted here. It is enough to note the unquestioned truth that freedom is a fact of religious life and history.

The importance of this fact in every realm of human thought and enterprise is plainly to be seen. Ruskin, who so strongly asserts in all his teaching the glory of submission, does 
yet most earnestly witness to the supreme value of individual liberty as shown in the story of the Arts. " "Go forth again," he says, "to gaze upon the old cathedral front, where you have smiled so often at the phantastic ignorance of the old sculptors : examine once more those ugly goblins, and formless monsters, anatomiless and rigid; but do not mock at them, for they are signs of a life and liberty of every workman who struck the stone; a freedom of thought, and rank in the scale of being, such as no laws, no charters, no charities can secure ; but which it must be the first aim of all Europe at this day to regain for her children." 1 But art is ever a reflex of life, most faithful and sure; the laws that obtain in Architecture obtain in all human existence; and the lesson that Ruskin read in the ancient Stones of Venice is written clearly everywhere for every eye. In Social life, while the duty of submission to authority is accepted by all good men as a normal rule of action, the right of protest and agitation and occasional revolt is not less fully held. The political organism depends for healthy life and growth on that free action of individual thought and judgment of which come change and non-conformity. Science, also, yields obedience to law and 
advances by submission to rule, but not less certainly it owes its life to the exercise of free inquiry and the fearless application of hypotheses. Bacon, Newton, Darwin were at once the apostles of law and the soldiers of revolution. Philosophy, too, as we have seen, owes much to the principle of discipleship, and all its teachers have been the inheritors of great possessions; but each master has ever been the messenger of freedom to his pupils, and each disciple has developed, and in measure contradicted, the instruction of his master. When we think of the relation of Plato and Socrates, of Aristotle and Plato, of Hegel and Kant, we think of dependence and yet of liberty. And so it is in all the domains of life. Everywhere we discern government and order, but everywhere also the fact of liberty. Inheritance is balanced by acquirement : discipleship is crowned by independence. As we read the history of thought and politics, of knowledge and art, we see on every page the greatness of law and the glory of Freedom: we praise the power of order and rule, and we honour the flag of rebellion; we reverence the King, and we salute the Revolution. ${ }^{1}$

1 An excellent statement of the case for freedom and individualism will be found in Dr. Greville Macdonald's Ethics of Revolt. 
Nor is the fact of Freedom less important in religion than in other spheres of human life. Newman says of private judgment: "We are far indeed from saying that it is never to advance in the direction of change or revolution, else the gospel itself could never have been introduced." 1 Mr. Froude bears the same witness, from another point of view, in a very characteristic passage: "In these two singular sciences (politics and theology) every one now makes his own creed and gives his vote by his own lights as to how he wishes to be governed. We could not help it, and we had but a choice of evils. There is no success possible to any man save in finding and obeying those who are his real superiors. But to follow mocksuperiors and be cheated in the process, who could wish that we should submit to that? If captains and officers were discovered to have never learned their business, and be doing nothing but amuse themselves and consume the ship's stores, the crew would have to depose them and do the best they could with their own understandings; but if the crew were persons of sense they would probably look out at their best speed for other officers, and trust to their own lights for as short a time as possible." ${ }^{2}$ Some will think that

${ }^{1}$ Essay on Private Judgment.

${ }^{2}$ Oceana, p. 20. 
Froude here attaches too high a value to Authority, but few will deny that he admirably illustrates the important function of private judgment and the ultimate fact of Freedom. The greatness of this element in religion appears to us quite clearly whether we regard the matter from the historical or the personal standpoint, whether we think of faith on its intellectual or its practical side, whether we have in view theology or devout experience. In the region of Ecclesiastical history we see that the restless speculations of the Greek combined with the direct intuitions of the Hebrew to produce the dogmas of the Faith, that the authoritative decisions of the Councils were the product of the free debate of generations and the long strivings of opposing minds and tendencies, that the intellectual forms of Authority were moulded in the fires of Freedom. When we analyse any of the Creeds, we see that it is a symbol of compromise and the Report of a majority. The study of Liturgies and Orders of Worship reveals the truth that while they all express, as to their spirit, the universal instincts of Religion, they not less surely owe their forms to individual minds and historical contingencies. The Prayer Book of the Church of England is informed with the spirit of 
Cranmer, and betrays the desire to utter the wants of many consenting hearts while conciliating the convictions of many varying minds. The Lutheran forms and symbols are what they are, because the intense individuality of the German reformer was what it was. The personality of Knox is stamped upon the Scottish Kirk; and ways of worship which seem to many good Presbyterians as almost of divine sanction, really owe their origin to national and individual contendings and opinions which were very human indeed. Certainly the importance of the power of liberty, as illustrated in the exercise of opposing intellects and the dominating force of great personalities, is clearly to be read in the records of the Creeds and the history of doctrinal and ecclesiastical forms. ${ }^{1}$

Hardly less significant is the fact of Freedom in the individual life of faith. St. Paul by the exercise of his free spirit accepted the yoke of Christ. St. Augustine by the very force of his individuality became the passionate servant of the Kingdom of God. Pascal owes his unique religious position, as at once a Roman

1 "Whenever a state of disease has appeared in the Church, there has been but one method of cure-that of an awakened, renovated, healthy consciousness." Döllinger, Preface to Kirche und Kirchen. 
and a Protestant, to the fearless use of his unique powers. Luther freely abjured one form of Authority to embrace another. Newman in the exercise of private judgment renounced its use. And this remains a characteristic element in the lives of all the teachers and saints. We cannot eliminate from the record of any of them the personal equation, the influence of the individual will, temperament and circumstance. Men under authority they were, and all as those who serve; but theirs was the sublime obedience of the free will, and they ministered each in his own way and in faithfulness to the law of his own personality. Nor is this true of the great and strong only, but in some degree of every humblest mind. The simplest man who has a personal experience of religious things knows that, while his faith has been given him from without, it has also been created anew for him in his heart, and has blended itself with his own proper life. The beliefs by which he lives are not merely the affirmations of the saints, they are the confession of his own spirit. His prayers may have been offered by a thousand hearts in many generations, by the wise and devout from of old, but they are new for him in the newness of the spirit ; they are his own by the right of his personality. $\mathrm{He}$ 
believes in the historic Jesus as one who lived and died and is alive for ever, who rules independently of his acceptance and his faith; but he knows also that Christ has been in some sense born in his heart, his higher self, his "hope of glory." The King, indeed, has stood at the door and knocked; but it has been of his own will that he has arisen and opened the door, and it is of his own will that he sups with his Master in the sublime intimacy and mystic equality of Faith.

Here is the fact of freedom in personal religion; vivid and real as the other fact of authority. The initiative of the personal will, the privilege of the conscience, the emancipation of the spirit, the right of inquiry of the individual mind,- these are not less truths of religious experience and history than the high prerogative of Prophet, Apostle, or Church. And whoever would think truly of Authority must think reverently of freedom. However great the element of trust, submission, obedience in religion, however real the Lordship of Christ and the Kingdom of Heaven,- - not less sacred, not less vital, is the glorious liberty of the children of God. 


\section{THE PROBLEM OF AUTHORITY}

To recognise the fact of Authority is at the same time to confront a problem. What are the bounds of Authority? Is it purely religious, or does it extend to dogmatic forms ; is it confined to ideas and emotions, or does it guarantee facts? What is its source and what its organ? How can we give it due weight and power without sacrificing the freedom of conscience, or limiting the sphere of thought and criticism? By what means are we to justify any one of its historical representatives? How are we to reconcile private judgment with objective revelation? These, and many more, are the questions that enforce the difficulty and illustrate the perplexities of the problem of Authority in Religion. ${ }^{1}$

When we consider this problem somewhat closely, we see that it is twofold. It is con-

1 On this whole subject, cf. Lord Acton's History of Freedom ; Newman's Essay on Development; Döllinger's Kirche und Kirchen; Oman's Faith and Freedom. 
cerned partly with the relations between faith and freedom, and partly with the difficulty of defining the true nature of Authority itself, and of justifying it in any one of its recognised forms. The puzzle is, in the first place, to reconcile the claims of liberty and obedience ; and, in the second place, to analyse the foundations of authority, and to vindicate the right of Church or Prophet, or Christ to be lord and master in the Kingdom of the Soul. It is true that these two phases of the problem cannot be kept entirely apart; but they can be broadly distinguished from each other in such a way as to clear the path of the student, and to prevent the waste of time and thought in profitless discussion.

\section{Freedom and Authority}

The problem, in its first aspect, is in the nature of the case insoluble. Given the facts of freedom and of authority, how do you reconcile their opposing claims, how define the frontiers of their dominions? How can you tell at what point the duty of obedience ends and the duty of revolt begins? When the question is put in this way, it is impossible to find for it a clear and competent reply. The difficulty is a practical one that concerns the conduct of religious life and the 
daily battle of faith. And the problems which life raises, life alone can solve. The two great principles of Order and Liberty have struggled together since ever men began to think and believe; their reconciliation is effected sometimes for the saints in those highest hours of faith when God and the soul are one, when service is perfect freedom; but for the common thought of men, and for the ordinary life of religious people, that reconciliation is as yet far off. It is the remote goal of evolution, the distant crown and reward of the faithful life. "The life of modern Christendom," writes the late Master of Balliol, "has suffered and is still suffering from an antagonism like that of the law and the prophets,-an antagonism which must continue till the advent of a higher manifestation of the Christian principle, by which the two opposing tendencies shall be reconciled and united." 1

But, while we thus admit that the task of perfectly adjusting the relations of Authority and Freedom in religion is in the meantime impossible, there are two considerations which lighten the burden of this conclusion.

I. It is not to be forgotten that this difficulty of defining with exactness the relation

${ }^{1}$ Evolution of Religion, vol. ii. p. 314. 
between Law and Freedom is not peculiar to theology, but is a permanent difficulty of conduct. A child should obey its parents; but there are times when it is justified in disobedience-what times are these? A subject should yield submission to the powers that be; but not always-when exactly is he justified in rebellion? A man should conform to the conventions of society; yet who shall say that he must always conform to all conventions? And who shall profess the wisdom that declares-"This and this rule you may break, and at this and this time you must conform." The categorical Imperative holds; there is such a thing as "ought," and whatever we ought we must and can; but who or what shall be our guide through all the mazes of the moral life, and meet us with a clear and competent reply in answer to our question: "What at this moment ought I to do?" The Ten Commandments utter true and tried directions for the conduct of life. But there are more things in the heaven and earth of our experience than are dreamed of in the Ten Commandments. There are realms of life in which no one of them applies: there are times when one Commandment seems to contradict another, and we know not which 
we must obey. At such moments of perplexity, in such conflict of duties, who shall limit the rights of the individual conscience; what power shall take from it the hard necessity of choice, or deliver it from the perils of Freedom?

"God's voice is of the soul: I do not say All voices of the soul are, therefore, God's :

And to discern the Voice amid the voices

Is that hard task that we were made for."

Thus the difficulty of deciding the rival claims of Freedom and Authority, of the individual judgment and the universal law, is not peculiar to religion, but is found in all the familiar ways of life. It is inherent in the nature of things, and is, indeed, essential to the development of the human personality. If the individual were utterly at peace with environment, if convention were one with liberty, if there were no conflicting duties, if the law for all were the same as the best for each, if the relation of religious authority to religious liberty were clearly and infallibly adjusted, and there were room no longer for the "venture of faith," then would that which is perfect be come and that which is in part be done away.

2. In connection with this first aspect of the Problem before us, it is also to be remembered, in the second place, that much 
which seems at first sight to be a conflict between law and liberty is really only a discord between one authority and another. When Newman said that the right of private judgment was the right to choose what faith you should believe and what law you should obey, ${ }^{1}$ he said what the hardiest Protestant must admit to be largely true. The Reformers of the sixteenth century were, from one point of view, not so much apostles of freedom as partisans of one rule against another. The man who rebels against social convention does so, if his revolt have any worthiness, under constraint of what he conceives to be some higher law of nature. Even the anarchist throws his bomb in the name of Humanity. The revolutionary seeks to overturn an existing order for the sake of some ideal State of which his soul is by choice a citizen. The conscientious man who hesitates as to the proper line of duty does so, not because he wishes to be free, but because he is in doubt as to which of two commands he should obey. He who lingers at the parting of the ways is not debating whether or no he should take to the pathless fields: he is only asking whether he should commit his feet to one road or another. It

1 Essay on Prizate Judgment. 
is of the essence of morality that a man should not wish to be free of law, but should be anxious to know the right law in order that he may obey it. Whoever says, "Here I stand. I can do no other. So help me God," is uttering a defiance of what he counts to be a lower authority in name of his allegiance to a higher. When a certain eminent man of our time resigned the Anglican Ministry, he said that he had left the Church in order that he might be "not less but more a Christian " ${ }^{1}$ that is to say, he forsook the society of his baptism because he believed that submission to its rule hindered his obedience to the law of Christ. And, in like manner, most cases of revolt or change of creed will be found on close analysis to be the mere transferring of allegiance from one rule to another. They illustrate the opposition of liberty and authority only in so far as the act is concerned by which a choice is made 'twixt faith and faith, order and order, church and church. The right of private judgment is, in practice at least, largely just the right of choosing masters. To remember this is to eliminate much of the theoretical perplexity that surrounds the conflict between liberty and law, and is at

1 Spirit of the Christian Life, by Stopford A. Brooke. 
the same time to realise afresh how tremendous is the Fact of Authority, and how small is the realm of human life that really lies beyond its sweep.

\section{Authority in Itself}

And so we come to consider the second phase of the problem, the aspect of it which presents to us the question-What are the sanctions of Authority itself? Admitting that it is impossible at the present stage of human thought to adjust perfectly the relations between authority and freedom, there remains the profounder question-What, as a matter of thinking, is the Source and Organ of Authority? How are we to justify to the mind the demands made by any one, or by all, of its historical forms? How shall we vindicate to the reason the obeisance of the heart?

When we have put this question we are face to face with the subject which must occupy our attention throughout this discussion. The theme of this book is not the conflict of Faith with Freedom; it is the positive exposition of Authority, considered/ not as an arbitrary power imposing its sway by force or penalty upon the minds and consciences of men, but as a constraining influence which shapes and guides the individual will 
and thought, which owes its life to the needs of men, which rules by the divine right of reasonableness-which is a thing, therefore, that is capable of rational defence. If it be urged against much that is said in the following pages that insufficient weight is given to the part played in the great Drama of human life by individualism, by insurgency and revolt, our answer can only be that this essay is not concerned with that side of thingswith the vindication of a freedom that is not in danger, or of a right of private judgment that is not in peril. What we have before us throughout this study is the other aspect of religion, the aspect wherein it presents itself as a power which brings to bear on the individual the weight of an experience that is deeper and a thought that is older than hisa power that constrains to belief and action, and is recognised by him who obeys it as existing independently of his own thought or will. Tribute has been paid in the last chapter to the Fact of Freedom ; nothing will be said in later chapters inconsistent with that tribute. But it will be found impossible in stating the case for Authority to be continually maintaining the opposite case as well. Let it be granted that large room must always be given for varying opinions, for solitary speculations, 
for individual effort, inquiry and even caprice; let us agree to honour the beloved company of the Insurgents, and to recognise that without them law would become convention and government despotism. But, having made these acknowledgments, let us proceed to consider, without encumbrance, the rights of that Dignity, and the problems presented by that Fact, which is called Authority.

"Authority," writes Principal Iverach, " is real, is ever present with men, is indispensable for the training and education of man. It is exercised in many ways and many degrees. It has to justify itself not merely by the exercise of power and by the ruder kinds of penalty; it has to meet the demands of human reason, and satisfy the requirements of the human conscience, and prove itself the guide, the counsellor, the friend of man." 1 Nothing could be truer; and the truth of it constitutes the real Problem of Authority. Authority in religion "has to meet the demands of human reason and satisfy the requirements of the human conscience "; it is not enough to say that it is a fact, it is necessary to show that it ought to be a fact. At the least it is incumbent on us to prove that the power for which we

' Hastings' Encyclopadia of Religion and Ethics, article "Authority." 
claim the obedience of men has an authentic origin worthy of respect; at the lowest, it is our duty to show that where the reverence of the heart is required the general assent of the reason may be fairly asked. While it may be true that no great historical Authority should be hastily rejected on the mere ground that the theoretical basis of it is for the moment in question; it is yet incumbent on theology to establish that theoretical basis without delay, and by every means in its power. We may justly ask of the individual that he be patient in a time of intellectual perplexity, and that he think well before he renounces his allegiance to the old and tried guides whose credentials may seem to him defective; but we may not ask of him to believe that no credentials are necessary, or to rest in a state of permanent discord between the loyalty of the heart and the misgivings of the mind. While an unreconciled opposition between reason and faith may be the necessity of the hour, it cannot be accepted as the normal lot of the religious mind. Dualisms may be sometimes unavoidable, but they are always dangerous. The power of an Authority may stand for a time, though the theory that aforetime was its vindication is gone; but sooner or later the want must be supplied, or else the 
power itself will pass away. For the nature of things is reasonable, and fact and thought are ultimately one.

(I) It is in the nature of things that this question of Authority should continually beset those who hold, and especially those who teach, the Christian faith. A gospel that makes so large a claim on the life and obedience of men must always expect to be challenged, and asked to establish its title. Whether we consider the evangel as a subject of thought in the mind of the student, or as a message presented to masses of men for their acceptance, it always bears an aggressive and conquering front. And wherever there is aggression, there is answering demand. Our Lord was Himself confronted with the question, "By what Authority?" and $\mathrm{He}$ was careful to answer the challenge to the utmost-by varied appeal to varied minds, by word and deed, by self-revelation and self-renouncing, by submission to the Cross, and by victory over Death. The Apostles had to face the same requirement; and the New Testament is in the main the record of the means they used to establish the rights of their gospel, to the Jew and to the Greek, to the unlearned and to the wise. ${ }^{1}$ The early Church, also, beset on

I See Scott's Apologetic of the Nerw Testament. 
every side by hostile forces, was compelled to establish an external order, and to formulate dogmatic symbols to which she might appeal. It is, further, to be remembered by those who would understand the dogmas and discipline of the mediæval Church, that she was under necessity to vindicate a spiritual power amid the conditions of a difficult age. The Supremacy of the Pope, ${ }^{1}$ the power of the Priesthood, the miracle of the Mass, the monastic Order-these things can all be understood by the man who considers the environment of early Christian and mediæval life. From the historic point of view these represent, in part at least, a coloured, imaginative, symbolical exposition of the content and grounds of religious Authority. The 'Reformation, again, is simply a new endeavour in fresh surroundings to grapple with the same Problem. The old solution had lost its power to convince minds that were no longer facing the questions of faith under the old conditions. An imaginative system had ceased to satisfy those races that were stirred by the dawn of the modern age. The mysticism of Rome had produced in practice superstition; its forms which had once been the expression of the free spirit had come to

${ }^{1}$ Cf. Church's Essay on The Letters of Pope Gregory $I$. 
be a paralysing tyranny: its ministries, which had truly interpreted the ethical needs of earlier days, were now the oppressors of the conscience ; its discipline, which had been of old the guarantee of liberty, was become a bondage. And so the Reformation, in the name of Freedom and Faith, of the understanding and the conscience, repudiated those renderings of Authority that had been for ages the official interpretation of the stately Mother Church.

Yet the Reformation was clearly not an end, but a beginning. The Protestant Church, having disestablished the old Authority, had to establish a new, having rejected the ancient Order had to propose one that should be able to take its place. If appeal was no longer to be made to tradition, and the organised visible Kingdom of Christ, and the perpetual miracle of the Mass; then how was the message of the Gospel to be commended to men-to what sanction might the preacher point as he urged the right of his evangel? How was the Protestant to show, not only, negatively, that the Roman Church had no credentials, but, positively, that the Reformed Church actually was an accredited prophet to men? If old Cæsar was gone, where was the new Cæsar? If it was necessary to say, "The King is dead," 
was it possible to say with a good conscience, "Long live the King"?

This was the problem the Reformers had to face; and they did so under heavy disabilities. For they made great claims on the human mind and reason. Their house of belief was large and heavy; and if a building is great, the foundations that are to bear it must be firm. If you take over from a ship a heavy cargo, your own ship that is to carry it must be of a sturdy build and strong. Truly the Reformers took over a great cargo from the old Church, and the new Church must be staunchly made to bear it all. The great mass of Catholic doctrine was retained by Luther and his men. The dogma of the Trinity, as defined by the Councils; of the Deity of Christ ; of Atonement ; of Judgment ; of Eternal punishment;-all these and many others they held even as their fathers had. They also made high claims for the visible Church, claims which sometimes amounted to theocracy. ${ }^{1}$ Now it is plain that religious teachers who made so great demands on the whole extent of thought and life-on will and mind and conscience-were likely to be straitly pressed with the question, "By what Authority?"

${ }^{1}$ See Luther's Letter to the Elector of Prussia ; also Calvin, Institutio, Lib. 4, cap. I. 
The answer given to this challenge by the Reformers seems to have been at first a free and informal one. They appealed to the religious consciousness, to the facts of the devout life, to their own experience, to the ministry of the Spirit. "The Reformation started from the personal experience of the believing Christian." ${ }^{1}$ It started, that is to say, on its religious side, from the personal experience of Luther, who, "rising above all anxieties and terrors, above all ascetic devices, above all direction of theology, above all intervention of hierarchy and sacraments, ventured to lay hold of God Himself in Christ." ${ }^{2}$ This spiritual emancipation of Luther was achieved through faith, which he defined as " personal and continuous surrender to God as the Father of Jesus." 3 Hence it followed that the ultimate Authority to which the German Reformer appealed in the beginning was not really Scripture, but the experience of faith. It is true that he held quite firmly the infallibility of the Word; but the Word was for him, not the entire letter of the Bible, but the spiritual content of it, the evangel which dwelt in it as the soul dwells in the body. And, inasmuch

1 Lindsay, History of Reformation, vol. i.

${ }^{2}$ Harnack, Dogmengeschichte (Eng. trans.), vol. vii. p. 184.

${ }^{3}$ Ibid. p. 185. 
as this spiritual content, this infallible Word, could only be discerned by faith, it followed that faith and its testimony became the ultimate court of appeal, the final seat of Authority. The Pauline message was truth to Luther, not because he found it in the Bible, but because it found him in the secret place of his soul. It was not the Scripture that guaranteed the Gospel, but the Gospel, received by an act of spiritual power, that guaranteed the Scripture. And so, in effect though not always in form, his answer to those who demanded proof of his teaching was: If God give you faith, you shall be enabled to discern that my witness is true. If you are given grace to cast yourself on God in Christ, yours shall be the Freedom of the Redeemed. If you can, by a direct act, trust in the divine Love, you shall find rest to your souls. ${ }^{1}$

But the Reformation had another side, intellectual and apologetic; and on this side the Problem of Authority presented greater difficulty and danger. The answer to this Problem that was founded merely on Luther's experience, and that appealed to individual faith, was an excellent one for the purely religious purposes of the preacher, but not so

${ }^{1}$ Cf. Sabatier, Religions of Authority, p. 175 . Cf. also Harnack, What is Christianity? p. 274. 
excellent when it had to be used as a weapon in theological argument. It served very well as a means of attack, but not quite so well as a means of defence. An appeal to the experience of the regenerate, and to the Word in the Scriptures, was too subjective a thing to serve the ends of defensive battle and of discipline. And the Reformation at the crisis of its intellectual history had a perilous twofold conflict to maintain. ${ }^{1}$ It had to resist the attack of enemies without and of heretics within. On the one hand, the apologists of the old faith, ceasing to wage a merely defensive war, pressed home on the Reformers the charge that they were teachers without a commission, that their gospel had no sanction, that their Church had no foundation, and their sacraments no warrant. On the other hand, there arose within the Reformed Society men who asserted the right of private jucigment to analyse and reject doctrines which the universal Christian consciousness, Protestant and Catholic alike, held to be of the substance of the Faith-the Deity of Christ,

${ }^{1}$ The stress of this conflict is illustrated by the rise of a Protestant theory of persecution; by the invocation, on the par: of both Luther and Calvin, of the aid of the secular power ; by the penalties inflicted by Reformed Orthodoxy on Anabapists, Unitarians, and Roman Catholics. Cf. Döllinger, Kirihe und Kirchen, pp. 54-74 (English edition). 
the Trinity, the Atonement, the obligation of the moral law. ${ }^{1}$ In the stress of this tremendous conflict against the combined forces of absolutism and anarchy, the Reformed theologians were compelled to establish a more objective form of Scripture Authority. It were vain to meet the commanding force of Catholic tradition with no stronger weapon than individual testimony. It were useless to set over against the Church of Rome, founded on Peter, a Church that was established on the consciousness of Luther. Equally vain were the thought of silencing heresy by appeal to a subjective standard. You could not prove that there were three Persons in the Godhead out of your own experience. You could not defend Infant Baptism by arguments drawn from the content of the faith. You could not silence the Antinomians by the mere anathema of your own conviction. You could not constrain the rebels to submit by an assertion that if they had the Holy Spirit they would know that they were wrong. Clearly, therefore, it seemed a necessity of the position that scriptural Authority should be maintained, in a somewhat literal sense, strong enough to 1 "Out of the Gospel and divine truth come devilish lies; from the blood in our body comes corruption; out of Luther come Müntzer and rebels, Anabaptists, Sacramentarians, and false brethren." Luther. 
resist the power and prestige of Rome, august enough to overawe the restless, destructive forces of a lawless individualism. And so we find the more liberal side of Luther's teaching as to the Bible gradually falling out of sight, and the more rigid and objective view of scriptural infallibility being more and more asserted. The distinction between the Word. of God and the Scriptures is always less clearly and firmly maintained. Heretics and Romanists alike are answered no longer in the spirit of the Luther who depreciated the Apocalypse, and did not care who wrote the Book of Genesis, and had small regard for the Epistle of James. They are now confronted more in the attitude of that other Luther who took his stand on the literal meaning of texts, and answered the Calvinistic and $Z$ winglian doctrine of the Eucharist by an appeal to the Word in its bareness, "This is my Body." The Protestant Confessions present the Bible as the only infallible rule of faith and practice. "The Canonic Scriptures, the Word of God, given by the Holy Ghost and set forth to the world by prophets and apostles, alone contain perfectly all piety and the whole rule of life." ${ }^{1}$

${ }^{1}$ First Helvetic Confession. Cf., however, Westminster Confession, cap. I., for a very careful and guarded statement as to Scripture. 
So an infallible Book came to be set in the place of an infallible Church. Great systems of theology and statements of doctrine were produced, that depended for the proofs of each proposition on an array of texts drawn indifferently from every part of the Scriptures; and at last it was possible to say that "the Bible and the Bible alone is the religion of Protestants." 1

(2) But if this be in any sense a fair account of the various answers given to the Problem of Authority up to the great classical age of Protestant dogmatic, what are we to say of the Problem as it presents itself to us to-day? What are the answers given now to the question of the ages?- "By what Authority?" The Roman Church has followed out to its logical conclusion the pathway it finally chose at the Council of Trent. The infallible Society has proclaimed an infallible Head. Rome replies to the challenge of the world through a living oracle of divine truth, a veritable Vicar of Christ on the earth, whose word in matters of faith and morals is the very voice of Almighty God. And yet that ancient mother Church has not come

${ }^{1}$ Cf. Sabatier, Religions of Authority, pp. 172-183; cf. also Moehler, pp. 282-304 ; E. Caird, Evolution of Religion, vol. ii. p. 310 ; Harnack, History of Dogma, vol. vii. pp. 187, I88, 246 . 
scathless through the long contendings, the bewildering discoveries, the eager, fearless inquiries of the restless modern age. The revolt of the Old Catholics against the Vatican Decrees was but the forerunner of that significant Modernist movement, within the Roman communion, which seeks to conserve the ancient forms without their old dogmatic meaning. To the mind of the Modernist, the Authority of the Church is religious, not intellectual. Her doctrines are true in the spirit but not necessarily in the letter; her creeds are to be interpreted freely by the individual mind; her liturgies and ordinances are but the symbols of devout aspiration; her priests are only the representatives and servants of the great religious democracy; her discipline is profitable for the nurture of the spiritual life; and her official deliverances are to be obeyed only as they express the results of Christian experience, and the witness of the common religious consciousness. The Modernist attitude is, in short, one that seeks to mediate between the Roman and Reformed Churches, combining the reverent and devotional spirit of the one with the intellectual freedom of the other. It is an attitude admirably represented by the late Father Tyrrell, who, being excommuni- 
cated by the Roman Curia, yet counted himself a "member of the Church according to the spirit" ; ${ }^{1}$ and by Professor Sarolea, who states the ecclesiastical ideal of the future to be "Protestant principle combined with Roman practice." 2 The best theological expression of Modernism is perhaps Loisy's IEvangile et l'Eglise-a book of peculiar beauty, subtlety, and suggestiveness. ${ }^{3}$ The whole significance, however, of this movement can only be fully understood by us if we remember that it is profoundly scientific in spirit, and has an authentic history that begins with the Hegelian philosophy and its application to criticism in Baur and his disciples. Its true sponsors are, in theology, Moehler and Newman ; in historical science, Döllinger and Acton; in criticism, the Tübingen School. It really represents in the Roman Church what Ritschlianism does in the Protestant; for each of these is an attempt, in the line of its own tradition, to preserve the affirmations of faith while asserting the freedom of the

1 Through Scylla and Charybdis, p. $8 \mathbf{1}$.

${ }^{2}$ Sarolea's Cardinal Newman, p. I73.

${ }^{3}$ The French edition of this work is now, unfortunately, out of print ; but the English translation, while it lacks of necessity the inimitable grace of the original, presents a true account of its substance, and so gives to the reader an accurate view of the drift and burden of the Neo-Catholic teaching. 
mind and the independence of science. Modernism has been denounced by the Pope, and its leaders are excommunicate; but its power continues to grow, and is full of menace to the absolutism of Rome. Its general influence is profoundly felt among the educated Catholic laity of England, France, and the New World; and its kingdom is likely to spread and increase. For, with all its excesses, it is yet a true child of our age, and has in it something infinitely attractive to those Catholics who revere the past and are faithful to the present and have hope for the future years. What the end of it shall be, it were.vain to prophesy. It may be the herald of a new division, and it may be the forerunner of a lasting peace. It may result in an absolute break with tradition, and it may prove itself the fulfilment of Richard Holt Hutton's prediction - "That Christianity which alone can conquer the earth will be a faith, neither so entirely rooted in mind and spiritual emotion as that of Luther, nor so studiously reflected in secondary organs and external institutions as that of Rome." 1

As to the Protestant Church: her position, in the matter of Authority, is at present, beyond all parallel, critical and troubled.

${ }^{1}$ Essays Theological and Literary, vol. i. p. 355. 
The difficulty which, beset the Reformed theologians in the beginning has never ceased to be the crux of Protestant Apologetics. It is so very hard a thing to maintain the right of Private Judgment without falling into a pure Individualism, or to use arguments against Rome that do not equally destroy every ecclesiastical form and every kind of historic faith. Martineau, in a striking passage, admirably illustrates this difficulty of orthodox Reformed theology. "The Protestant can hardly assail the Roman Catholic without resorting to weapons of argument which may wound himself. Does he slight and deny the supernatural pretensions of to-day-the visions, the healings, the saintly gifts of insight and guidance more than human? It is difficult to do so except on grounds more or less applicable to the primitive reports of like phenomena in the first age. Does he insist on the evident growth, age after age, of Catholic Dogma, as evidence of human corruption tainting the divine inheritance of truth? The rule tells with equal force against the scheme of belief retained by the Churches of the Reformation: there is a history, not less explicit and prolonged of the doctrine of the Trinity and the Atonement, than of the belief in Purgatory and Transubstantiation. 
Does he show that there are missing links in the chain of Church tradition, especially at its upper end, where verification ceases to be possible? He destroys his own credentials along with his opponents', for his criticism touches the very sources of Christian history." 1

But the main difficulty of the Protestant Church respecting the question of Authority has not been evolved in the conflict with Rome, but rather through the developments of its own principle of Private Judgment. Reformed theology has found it true that private judgment is a dangerous instrument, apt to "be chopping at our own fingers" when we only mean it to make "a dash forward at truth." ${ }^{2}$ Knox found it difficult to reply to Queen Mary, when she said that her conscience did not agree with his as to what the Scriptures taught "She keeps ever crying, 'Conscience, conscience, " he complains. ${ }^{3}$ And the continual talking of "conscience, conscience" hàs always been a trouble in the Protestant communion. The uninstructed mind is apt to adopt singularly perverse notions as to truth and duty. And persons of strong in-

${ }^{1}$ Seat of Authority, p. 170 . Cf. also Acton's Essay on Protestant Theory of Persecution.

2 Newman, Essay on Private Judgment.

3 Taylor Innes's John Knox, p. I26. 
dividuality are prone to forget the dangers and losses of schism. The habit, too, of resorting to texts of Scripture in their literal sense, as infallible oracles, apart from their relation to the whole of the Gospel, and apart from historic experience, has produced often inconvenient results. Hence innumerable sects, and manifold protestings; "playing at Churches"; paltry self-assertions; tawdry flags of trivial revolt; amateur papacies; independencies without dignity, and anathemas without weight. Hence those divisions and strifes, those excesses of private judgment, which render it so hard a thing for the Protestant Church to frame any coherent answer to the question-By what Authority?

And yet the chief perplexity of those within the Reformed communion who seek to establish a sanction for the Gospel is not created by the mere fact of sectarian divisions and rivalries, or even by the vagaries of private judgment. The roots of the trouble are deep in the substance of modern knowledge and life. All the varying tendencies and forces of the latter age seem to conspire together to shake the throne of Authority. In politics, the democratic theory has accustomed men to find in themselves the sanction of government. Philosophy has tended to produce, either, as 
in the system of Spencer, a pronounced individualism, or, as in Hegel, a doctrine of the Free Spirit which tends to destroy, or greatly weaken, the power of historic authority. Scientific method, too, applied to the records of Revelation, has attacked the very basis of Protestant theology. It has destroyed the traditional beliefs as to the date and authorship of one book and another; it has analysed the Synoptic Gospels and revealed their composite character. It has sought to show that all the New Testament writings are books of Apologetic, and contain elements of differing value. In the hands of some evangelical scholars it has been used to attack the Johannine authorship of the Fourth Gospel, to disturb our certainty as to the words of Jesus, to show us St. Peter at war with St. Paul, and St. Paul at odds with himself.

It is true that the extreme results of criticism are by no means established, or even likely to stand. When we read Principal Drummond's book on the Gospel of John with its strong and scholarly defence, from the Unitarian standpoint, of the old view as to the authorship; when we study Dr. Martineau's confident and almost contemptuous attack on the authenticity of the Book of Acts, and compare it with the later and weighty vindication of 
the same book by Sir William Ramsay; when we peruse with amazement Van Manen's argument that the Apostle Paul was not the author of the Epistle to the Romans ; ${ }^{1}$ when we contemplate the learned toil of Schmiedel, which first produces chaos, and then evolves from it again a somewhat ghostly cosmos $;^{2}-$ we feel that the conclusions of critical science share in the uncertainty of all human things. We see that there is much to justify the attitude of at least suspended judgment as to these matters which characterises the plain man, and that in relation to many of the questions raised by New Testament scholars, "They also serve who only stand and wait."

But, while this is so, it is certainly true that the doctrine of Biblical Inerrancy and Plenary Inspiration, in the old sense, is among the things that have been and the powers that are dead. We cannot any longer establish doctrines by an appeal to the mere letter, nor attribute the same value to the logic of Paul as to the teaching of Christ. We may not set an infallible Book, in its entirety, over against an infallible Church, nor say that the Bible alone is the religion of Protestants.

And the result of all this, as it affects the

1 Encyclopadia Biblica, article 'Epistle to the Romans.'

' Ibid., article 'Gospels.' 
problem before us, is to create a position of extreme perplexity for those whose office it is to teach Religion, whose care it is to commend Revelation to the consciences of men. On the one hand, we know that the old imperial facts of faith remain, that the Scriptures contain a veritable word of God, that the testimony of the Church is worthy of veneration, that Jesus is Master and Lord. But, on the other hand, we find it hard to construct a rational basis on which to establish our witness. We experience a difficulty in showing, to men of average knowledge, that the gospel has a right to their allegiance, a sovereign claim upon their lives. It is not to be denied that current views of inspiration present a most elusive aspect to the common mind, that the basis of the modern Church is difficult to see, that the "Saviour in the newer light" is apt to seem no Christ at all. Criticism has given us a Bible rich and wonderful for the student, but hard for the people to grasp as an objective Unit of faith. It may, no doubt, be true that we understand Christ better to-day than $\mathrm{He}$ has ever been known before, that this century "is face to face with Him as no century has been since the first." But, at the same time, it is more difficult to proclaim with assurance the whole of His 
teaching, and to assert with conviction the whole of His life. It is less easy than it once was to present an evangel which men can see to possess an authentic power. Never since the Reformation has it been so hard as it is to-day to prove, by arguments easily grasped, that the teachers of Religion may speak with authority. It can hardly be questioned that a Church without a Canon of scripture, without a theory of Inspiration, and with a nebulous Christology, is a Church that is in trouble. Is this not largely the case of the Protestant Church, in most of its branches, to-day?

We find ourselves, thus, in a strange and anomalous plight-very strong in faith, but somewhat weak in theory; very sure of the facts of the Gospel, but greatly in doubt how best we may prove and enforce them; rich in religious possession, but wanting in means of attesting our wealth to those who may doubt it. This is our position; it is one that is sufficient for the day, but cannot provide for the morrow. It is a great privilege, but an anxious stewardship. We want a position of less freedom, perhaps, but also of less responsibility-more limited, it may be, but also of greater defensive power ; not poorer in individual courage and initiative and thought, 
but richer in the elements that make for unity and discipline and 'striking force.'

It is idle to think that we can face the task that lies before the Church, without a discipline, an order, and a creed that has authority. Without these, how can we teach the young, how evangelise the multitude-how, especially, commend our gospel to an educated age, scientific in training, critical in spirit, accustomed to work on well established facts? To men of such an age, it is more or less interesting, perhaps, to know what an individual clergyman thinks, but it is not in the least important. The important matter is why he thinks what he declares, and what authority he has, and who gave it him. Nay, to the educated man, preaching must almost appear a dignified form of impertinence, if the preacher is understood to be speaking in his own name a message evolved in his own consciousness. We may listen to a prophet on these terms; but the average pastor and priest is not of the race of the prophets. ${ }^{1} \quad$ Nothing but the history that lies behind a message can give it force, when spoken by common men. Nothing but the sanction of a well-proved spiritual

1 Of course, we recognise that there is something of the prophet in every man who interprets with conviction the realities of faith. 
power can lend a gospel sacredness and beauty for a generation that thinks and understands.

In the meantime, there is much confusion and a great unrest. Some are preaching the Gospel in exactly the old forms, and assuring themselves that the old dogmatic foundations remain; some are proclaiming the solitary Conscience as the only guide of man ; liberal Catholics are seeking to commend the spiritual authority of the ancient Church; not a few are turning in despair to Rome, as it is, in all the fulness of its traditional doctrine and all the arrogance of its claims; others are striving to make the general sense of the Scriptures the ultimate Rule of Faith; and others are still crying, "Back to the historic Christ"; while many are going on in the ways of their fathers, keeping to the ancient paths, but haunted by a constant doubt that the Basis of Belief is gone. Perhaps this state of uncertainty, of varied and doubtful answers, is a necessity of the time. It may be that the Church must even wander a while in the desert : it may be that the word of reconciliation cannot be spoken till the thought and research of this age have performed their perfect work, till the uses of its labour are done. But surely, at the least, we can work towards the coming end; 


\section{THE PROBLEM OF AUTHORITY 55}

surely we may seek to suggest to ourselves grounds of patient waiting; surely we may hope to convince each other that there is reason enough for trust and confidence, for sincere and honest teaching, for resting at peace in the Household of Faith. 


\section{CHAPTER IV}

\section{AUTHORITY AND INFALLIBILITY}

IT is necessary at the outset of any positive treatment of religious Authority to consider its relation to Infallibility. Are these two things identical, or at least so closely allied that you cannot separate them in thought the one from the other? Must you assert of a power that it is incapable of mistake, before you can say that it is worthy of obedience? Is it a condition of trust, in matters of faith, that the object of confidence should be theoretically viewed as raised above the possibility of error? Must every Authority dwell in a place wherein there is light and no darkness at all?

In seeking an answer to this question, it is well to remember that, beyond the religious sphere at least, men do not as a rule assert inerrancy of those powers and teachers to whom they yield submission. The right of every government is recognised by its loyal subjects, but they do ${ }_{56}$ dream of saying that 
it is incapable of mistake. Even the most autocratic ruler fails to affirm his own infallibility ; and the continued existence of his power depends on the support of the general consent of his subjects. The great leader who commands the passionate homage and discipleship of men is not regarded by his most ardent followers as in any absolute sense beyond the reach of error. No enlightened soldier of Hannibal or Cæsar or Napoleon would have committed himself to the abstract assertion that the chief was incapable of tactical blunder. Nor are the supreme teachers of the world really held as in any sense infallible by those who love them most-not Dante or Shakespeare, not Newton or Bacon, not Plato or Kant. While even the individual conscience itself, the guide and counsellor of every man, is not held immune from error by him who obeys it. If a man were to say, "I must follow my conscience," and you were to press him with the question, "Do you then suppose your conscience to be infallible?" he would be compelled to answer, "No." He would remember that the faculty of moral judgment within him is involved in the general weakness of human nature, and is compelled to work in intimate alliance with the fallible powers of the understanding. Doubtless the conscience 
would be an absolutely inerrant oracle if it dwelt in a perfect life; certainly when we predicate of Jesus that He was without sin, we assert that in Him the moral judgment never went astray. But, in the case of the ordinary man, it is true that he yields reverence and obedience to the ethical deliverances of his soul, yet does not claim for them ideal, theoretical perfection.

It is thus apparent that, beyond the borders of religion, there is the recognition of many powers and masters, but there is nowhere the assertion regarding them that they are without the liability to err. Men obey governments, follow leaders, accept the word of teachers, tread the path of life in loyalty to the voice within; but they do not say of government, master, leader, or conscience that it cannot ever go astray, and has not ever made mistakes. They recognise Authority, but not Infallibility.

But, going further, we may venture to suggest that the same distinction should be recognised by the Christian apologist to be valid in the Kingdom of Faith. Theology is unnecessarily burdening itself, when it seeks to establish a theoretical inerrancy as the attribute of all authentic religious powers. The attempt thus to identify Infallibility and Authority is indeed a hopeless and impossible 
task. There is no logic that is able to prove of anything human that it cannot err or go astray. A fallible reason can never suffice to establish infallible power. No amount of uncertain evidence can establish a certain conclusion. You can, indeed, assert that a book or a church is infallible; but you cannot attempt to establish your case except by the use of arguments that may or may not be sound. Even if a pure and perfect oracle existed on the earth, the words that it spoke would have different meanings for different minds, - would be variously interpreted according to the environment, the history, the education, the capacity of those that heard. Is it not written that, when a voice came from heaven, some said it thundered, and some said an angel spake?

It is, no doubt, true that the "Deposit of Faith," the soul of Revelation, is divine-and whatever is divine is without fault or mistake. But then, it is also true that the historical medium of Revelation, its body and instrument, is human-and whatever is human can err. "Not heaven itself can pour more or purer spiritual gifts into you than your immediate capacity can hold. Who can better state the condition of all Revelation than the Apostle Paul at the very moment of imparting it,- 
'We have this treasure in earthen vessels that the excellency of the power may be of God, and not of us.' Far from affirming that the gift incurs no liability in transmission, he plainly says, "it cannot come to you without the alloy of humanity: whatever you find in it that is less than perfect, charge upon us,- - for all the rest give glory to God." "1 It is this human element in Revelation, this matter of the earthen vessels, that, taken along with an incurable tendency to error in the minds to which Revelation appeals, renders it impossible to establish a doctrine of objective infallibility. "Infallibility, inerrancy, are categories which men cannot use." 2

But here, as elsewhere, the saying holds, " no strength, no need." The task of identifying authority with infallibility is impossible, but it is also irrelevant. "It is a common fallacy," writes an eminent theologian, "to demand an infallible certainty in religion, never required elsewhere; and to urge as valid against religious belief objections, founded on some transcendental theory of a certainty outreaching all finite intelligence, which are instantly rejected as unworthy of

1 Martineau, Seat of Authority, p. 288.

2 Principal Iverach, article 'Authority,' in Hastings' Encyclopadia of Religion and Ethics. 
notice both in physical science and practical life." 1 The essential attribute of Authority is not theoretical inability to err $;^{2}$ it is ability to serve the ends of its existence, to constrain the will, convince the mind, "urge men's thoughts to vaster issues"; to comfort, counsel, and direct, to commend itself to the conscience, and to lead in ways of righteousness and paths of peace. Whatever is thus endued with strength is certainly crowned with authority. The child does not believe his teacher to be of limitless understanding or unsearchable wisdom; but he knows that his teacher is able to give him, what he cannot find for himself-knowledge. The soldier does not suppose the great leader in whom he trusts to be incapable of error, but he believes he can lead him to victory. The good citizen does not affirm that the law is infallible, but he is sure that it is good, and that in submission to it is his own best freedom. And so the Teacher, the General, the Law, being possessed of power, are sure and strong authorities. It is not otherwise in the religious sphere. The human, fallible element in Revelation does not rob it of authority, for it does not rob it of strength. Although the

1 Harris, Philosophical Basis of Theism, p. 86.

${ }^{2}$ Cf. Murphy, Scientific Bases of Faith, p. 174. 
words of prophets come to us through a broken, imperfect medium; although the story and teaching of Christ are reported by fallible witnesses, and His Figure and Cross are seen 'mid changing lights and many shadows; although the Church is rent with schism and burdened with errors; although the divine voice in our hearts is heard through the clamours of sense and care : yet all these have, each in its own measure, grace to enlighten and strengthen and guide and redeem, and are therefore, in varying degrees, our masters and lords.

Is there, then, no such thing as religious certainty? Are we not able to get beyond a probability in matters of the spirit? Is there not a reality called Assurance of faith? Is the test of theological truth simply usefulness value for the practical ends of life? And does there remain for the believer no "glad confident morning," in the light of which he is able to say, 'I know and am sure'?

To answer this question in the darker sense would be to contradict the testimony of an authority for which we claim the fullest sanction, the universal experience of the saints. For the witness of the saints in every age is that they are sure of the world of the spirit with a radiant certainty surpassing their knowledge of the world that appears. The Apostle 
Paul looked not to the things that are seen, but to the things that are not seen, knowing that the things that are seen are temporal, but the things that are not seen eternal. To the mind of Newman there were two "luminous, self-evident realities"-God and the Soul. Tennyson truly expresses the conviction of the devout in the familiar line:

"Closer is He than breathing, and nearer than hands and feet." Sir Philip Sidney, that most reverend witness, is very sure of the spiritual riches :

"Leave me $O$ love that reachest but to dust, And thou my soul aspire to higher things. Grow rich in that which never taketh rust, W'hatever fades but fading pleasure brings."

How great a certainty, too, as to the objects of faith is expressed by these two sayings of Molinos and à Kempis, " $\mathrm{O}$ thou lovely greatness that passest the knowledge of the sons of men "; "Love all for Jesus, but Jesus for Himself." And, in like manner, a brilliant exponent of mystical thought and feeling thus expresses the real spirit of Catholic faith towards Christ: "Among ten thousand times ten thousand I should know Him, and amid the crashings of a universe I should hear the faintest whisper of His voice." 2

${ }^{1}$ Golden Thoughts of Miguel Molinos.

${ }^{2}$ John Inglesant, by John Henry Shorthouse. 
Of the same nature is the testimony, not only of seers and saints, but in some measure of all religious minds. A sense of assurance and confident belief is of the substance of every devout experience. Prayer is impossible apart from the certainty that God is, and that $\mathrm{He}$ rewards those who seek Him. Adoration and doubt cannot dwell together in any soul. The power of Christ to lead and comfort and redeem, depends on a sure and certain faith that $\mathrm{He}$ is able to do these things. Religion without certainty is religion without strength.

To admit this, however, is not to contradict or weaken the statement that we do not have to prove the theoretical, objective infallibility of a Power before we can claim for it authority. For the experience of certainty in religion is not attained by reasoning; it is the direct achievement of faith. "Certainty," writes Dorner, "is a vital spiritual state." 1 It is an individual, subjective possession which logic cannot give and cannot take away. You can prove the existence of God so far as to produce a rational conviction ; ${ }^{2}$ but only the direct act by which the soul "casts itself on Him" can make that conviction sure. You

1 System of Christian Doctrine, vol. i. p. 62.

2 Ibid. vol. i. pp. 212-343. 
are able to commend the authority of the Church by an appeal to history, and found it securely on the "corporate conscience." But only the devout mind, abiding in the Christian Society, joining in its prayers, receiving its sacraments, can really know with certainty that the Church is ordained of God. It is possible to establish, on many grounds, the Lordship of Jesus; but faith alone can enable a man to share in the absolute homage rendered to Christ by the Apostles. No man says that Jesus is Lord except by the Spirit. Not without personal trust and experience is it possible for any one to understand the attitude of mind that confesses:

"Our wills are ours, we know not how.

Our wills are ours, to make them thine."

Certainty, in short, as to things of religion comes of faith, and exists only in the devout spirit.

"Whoso hath felt the spirit of the Highest Cannot confound or doubt Him or deny."

But to be rid of doubt and denial without the immediate feeling of the spiritual power is never possible. To believe in the light is within the reach of reason; but so to be in the light as to see light clearly, is the 
privilege of personal experience. Authority becomes infallible only in the kingdom of the soul.

We conclude, then, that the attempt to prove logical inerrancy, as a necessary attribute of religious authorities, is an impossible and irrelevant task. It is impossible by the laws of the human mind and by the nature of historical evidence. It is, at the same time, irrelevant, because the credential of authority is simply power-power to rule and bless. This essential thing it is possible to establish. We can prove, by the testimony of many witnesses, a capacity to govern and teach and do good; we can show that the secret of this capacity is rational. But when once this task is accomplished, theory has done its work; the further step which leads to Christian certainty must be taken by the individual soul,-it is the "venture of faith." When' a man has recognised any one of the divine Ministries as possessing authority, because able to do for him what he could not do for himself, it must be his to put his trust in it by a personal act of the spirit. If, then, the authority fulfils its promises to him and satisfies his hopes, it becomes the object of a confidence that knows no limit; it is hence- 
forth, for him, a strength that cannot fail and a voice that cannot lie.

Authority has an objective reality and proves itself by power; but infallibility exists only as a spiritual affirmation in the minds of faithful men

" in whom persuasion and belief Has ripened into faith, and faith become A passionate intuition.". 
THE THEORETIC SOURCE AND ORGAN OF AUTHORITY

THE consideration given to the subject of Authority in preceding chapters has been, for the most part, external and inductive. We have seen that Authority is a fact of all life, but especially of religion. We have recognised the problem it presents as it stands over against the fact of freedom, as it makes its claim on the allegiance of the will and heart, as it challenges the scrutiny of the mind. We have also recognised that, while it is to be ideally regarded as incapable of error, we cannot claim infallibility as the essential note of it, considered as an object of historical observation or as a thing to be accepted by the understanding. We cannot, and need not, prove that a power is infallible in order to secure its reasonable recognition; we are only under a necessity to show that it is a force which rightly constrains to belief or action, and 
is recognised by him who obeys it as existing independently of his own thought or will.

But, having suggested these points, it is now necessary to proceed to the theoretical aspect of the matter, and to ask ourselves what the rational basis of authority is-what its source and what its organ-as a subject of speculative thought. Our concern in this chapter is not with the principle of authority as it appears in any concrete form, but with that principle as it presents itself to reflection -as it excites the curiosity of the reason. Just as the scientific observation of phenomena leads in the end to the desire for some hypothesis which shall give to these intelligible unity; just as the study of social life involves the endeavour at last to form a theory of the State; just as the experience of faith must sooner or later issue in the attempt to construct a theology;-so the recognition of the facts of Authority compels the mind, by the necessity of its own nature, to seek for some rationale of these facts, some thought which shall bring them to the harmony of law.

Now it is evident that the theory of Authority in religion really presents to us two questions-one as to the ultimate Source of this power, and the other as to its universal Organ. It is the nature of thought to be ever seeking 
after unity; and thought about Authority must be always asking, in the first place, what the one ideal source of it is, and, in the second place, what we must conceive to be its one ideal instrument in history and in life.

\section{The Source}

But the first of these questions presents no real difficulty. We take for granted the belief in God, for without that belief the question of religious authority does not emerge; evidently we cannot debate about the ruling power in the life of faith and devotion unless we are agreed that faith has an Author and prayer an Object. The problem before us emerges only when we consider the experience of those who accept some form of Theism as a thing beyond dispute. It is a question that might be in debate between Hegel and Ritschl, between Luther and Erasmus, but not between Spencer and Huxley or Mill. But if Theism be granted, there can be no difference of opinion as to the ultimate Source of religious authority. All authority, for the Theist, rests on the will and voice of God. Science, as it discovers the laws that govern the Universe, is simply a servant of Revelation-it makes plain the ordinances of the Most High. Exact knowledge is the perception of that 
which commends itself to all intelligences as true because it is a transcript of the perfect intelligence. The reasonable understanding of the world is the understanding of the Reason that is in the world. ${ }^{1}$ All civil and political rule, in like manner, so far as it is legitimate, exists by right divine-the powers that be are ordained of God. The ultimate sanction of moral law also, is the Divine nature and will. This remains true whether you conceive the rules of morality as generalisations from experience or as direct intuitions of the conscience, whether you define the Good as that which gives happiness, or that which tends to self-realisation, or that which is fit to be law universal. Because it is evident that whatever conscience rightly perceives, whatever experience truly asserts, whatever makes for rational happiness or self-possession, or is fitted to be the law of conduct always and everywhere, is a revelation of the divine will for man. The Right is that which accords with the nature of things; but the Nature of things is God. And, in like manner, everything that speaks with true authority in the religious sphere must owe its power to the indwelling divine spirit. No word of Eternal life can be other than the word of the Most High. No

1 Cf. Green's Prolegomena of Ethics, Book II. cap. I. 
prophet can have any true dominion over us at all unless it be given him from above. The secret place of power in every temple must be a place where God is. Whoever discovers the source of strength in any religion, discovers Him of whom and through whom and unto whom are all things.

"God is law, say the wise; oh Soul, and let us rejoice, For if $\mathrm{He}$ thunder by law, the thunder is yet His voice."

\section{The Organ}

Up to this point the difficulty does not appear. If there be an infinite Spirit, immanent in the universe and in the soul of man, then in Him must be found the ultimate source, as of all power, so also of Authority in religion. But whenever we go further and ask how this ideal Authority is mediated in history and in life, we find ourselves within the region of doubt and of debate. The problem arises when we face the question-Where is the divine voice to be heard? Where is the place of the oracle? What is the Organ of religious Authority in the actual experience of men?

Now it is clear (as has been suggested before) that we do not reach any answer to this question by simply asserting the supremacy of one or other among the historical embodi- 
ments of authority-as the Christian Society, Tradition, or the Bible. If we affirm the divine right of any one of these exclusively we find ourselves at war with the established facts of experience; for experience refuses to admit so narrow a claim. We find ourselves also compelled to vindicate the solitary inspiration of one witness by reasonings which tend to prove all inspiration impossible; since the same arguments which are used by the Protestant against the Church can be employed by the Rationalist against the Scripture; and the very objections which the Theist may take to the Lordship of Jesus, the Atheist may take to the authority of the religious consciousness itself. The attempt to prove the existence of one only objective Oracle of God in history is to contradict fact and to enter the path of universal doubt; it is certainly not "an attempt religious" or "an attempt conservative."

Nor, on the other hand, are we in any better case if we accept the claims of all the different religious powers, and affirm that in a consensus of these is certainty found. It is a simple matter to say that the voice of God speaks through the Prophets, the Christ, the Church, the Conscience, and that when all these agree together their witness is true : 
but in saying this we make no contribution towards a theory of the matter, and have advanced no step nearer to a unity of thought. For attainment of any theoretic security it is necessary that we reach below the many to the one, and discover what is the common element in the different historical forms of that power in religion which constrains to belief and action. It may be said, indeed, that we have already reached such a unity when we have confessed that the source of all power is God; since, if this be so, a common element in all authorities must be the Voice of the Highest. But this is a purely ideal solution; it belongs to the region of abstract thought, and does not absolve us from the search for an actual unity of experience among the facts of faith. Suppose we say with the wise of old ${ }^{1}$ that the ideal source of music is to be found in the celestial harmonies, is indeed the harmony of the divine nature, we are yet called to assert that music as a matter of human knowledge has one organ of expression, namely, the rhythmical movement of the air. This we know to be the organ of music, whatever its kind, whatever the instrument by which it is interpreted. And

1 Pythagoras, Plato; cf. also Shakespeare, Merchant of V'enice, v. i. ; Milton, Arcades. 
in like manner, although we say that the primary ideal source of authority is God, and that its common note through all its forms is the divine voice; we are yet under necessity to seek for a secondary unity among the phenomena of authority as it appears in the world of things - to find the common medium through which the divine voice speaks. Just as music which is one in its ideal home in God is one also in that material medium through which it reaches us in concord of sweet sounds; so also we must expect that the authority which has its ultimate source in the divine nature shall find one organ in human things, and have through all its many instruments one common element.

There are, then, two conditions which any satisfactory theory must fulfil. In the first place, it is required to cover all the facts, not excluding any authentic form of religious life, finding room for all the phenomena of Christian experience, taking account of the different types of faith in which the Soul has found the Bread of Life. It cannot refuse to consider the witness of Mohammedan or Buddhist; or consign to outer darkness those in our midst to whom the Catholic tradition has not commended itself, but who have plainly shown that they have meat to eat that 
the world knows not of. It must also, in the second place, reach some unity of thought, get beneath every manifestation of religious authority and find the hidden power which, through all the phases of revelation, so variously appears.

But the only theory which seems to offer any hope of fulfilling these conditions is that which declares the Organ of ultimate religious Authority to be the Soul in communion with God. This theory has been held by thinkers of many opposing schools, and in many varying forms. It has been associated with phrases like "the inner light," the "inner witness," the "religious consciousness," the "testimony of the Holy Spirit," and the like. It is taught in very different fashion by rationalist and mystic, is the creed of Molinos as of Martineau. Sometimes it has seemed to involve the rejection of all Authority outside of the individual life; sometimes it has lent itself to a mere pietism; sometimes it has been made the excuse for the wildest vagaries of religious eccentricity. And yet we feel that it contains the essential truth, and alone has any promise of reconciliation. If in some form of this theory a solution of the problem before us is not to be found, then we must surrender the hope of reaching any 
unity of thought regarding the Organ of Authority in Religion.

It is true, indeed, that the phrase "the Soul in communion with God" has a very indefinite sound. But when we are speaking of ultimate spiritual facts it is difficult to be at once precise and adequate. The term "God" is s not easily definable, any more than the term "soul" or "communion." The world awaits, but does not expect, the appearance of a definition of these which shall secure the assent of the understanding, while at the same time satisfying the requirements of faith and the testimony of experience. The consideration, however, which leads us to use the term "soul" here, rather than any other, is easily stated. The advantage of this term is its comprehensiveness. "Conscience" would be too narrow a word, since conscience is generally supposed to be the faculty, merely, which deals with questions of conduct. "Reason" would also be open to misunderstanding, being so closely associated with the idea of logical processes. "Spirit" is a word used to describe something common to the nature of God and Man. "Mind," also, would seem to exclude certain elements that belong to religious life. Rather than any of these, therefore, we employ the more general 
term "Soul." When we speak of the soul we are far from having in view the $\psi v$ u $\eta$ of the Pauline psychology; we are not implying any possibility of dividing the ego into exclusive compartments; we are not forgetting that all the activities of the mind are rational, nor excluding the understanding from a share in religious life; we are not thinking in any scholastic way at all. By the soul we mean simply the human personality regarded on its spiritual side. We say that, as an implicate of Theism, it is to be asserted that the infinite Spirit is in relation with the finite, that God has a "dwelling" in the "mind of man." The mind of man, considered as capable of this relationship, as fitted for this indwelling, we call the soul. And it seems to us, further, that, since we cannot reach anything deeper or more universal than the fellowship of the human spirit with its Creator and Father, we must say that the Soul in Communion with God is to be ideally regarded as the great immediate Organ of religious Revelation and Authority.

\section{III.}

The difficulty about this theory is not its abstract reasonableness, since it is not really denied by the great religious teachers that 
God is in direct relation with the soul of man. Ritschl, indeed, seems to deny the immediate communion of the finite spirit with the divine, but at least he believes that Jesus had direct access to the Father. Herrmann finds the common element in all religions in "a sense of being possessed, so strong that a man must say, 'This is God.'" Without this "experience of God all else is so empty that it does not deserve to be called religion." ${ }^{1}$ Pfleiderer teaches that the communion of God with the soul differs from that of man with man only in this that it is perfect, inasmuch as God is not shut out from us as we are from each other, by "the limits of individuality." ${ }^{2}$ To the same effect is the testimony of Martineau throughout his writings. Calvin, as is well known, taught the doctrine of "the Inner Light" in a form singularly full and clear. "God," says Luther, "teacheth man only inwardly." Every student of the Puritan divines will feel that one of his chief debts to them is the conviction they impart of the communion of God with the individual soul. "Conscience," writes John Owen, "is the territory and dominion of God in man, which he hath so reserved to Himself that no human

${ }^{1}$ Communion with God, pp. 17, 18 (2nd edition, pp. 19, 20).

${ }^{2}$ Philosophy of Religion, vol. iii. p. 305. 
power can possibly enter into it or dispose of it in any wise." ${ }^{1}$ Newman also finds in the phenomena of conscience "the creative principle of all religion, even as the moral sense is the principle of ethics." ${ }^{2}$ Gladstone speaks of "that personal and experimental life of the human soul with God, which profits by all ordinances but is tied to none, dwelling ever, through all its varying moods, in the inner courts of the sanctuary whereof the walls are not built with hands." ${ }^{3}$ In short, the communion of God with the soul is the common assertion of religious minds. Thomas à Kempis utters the universal confession of all the devout in thought when he says : "Let not Moses speak unto me nor any of the prophets, but rather do Thou speak, O Lord God, inspirer and enlightener of all the prophets; for Thou alone without them canst perfectly instruct me, but they without Thee can profit nothing," 4 "Strange as it may sound to many, there is no proposition on which theologians of all schools are more willing to agree than this-that all knowledge of God, and consequently all religion, rests on Revelation." 5 But if this is so, it seems to follow that the

${ }^{1}$ Moffatt's Golden Book of John Owen, p. 240.

${ }^{2}$ Grammar of Assent, p. I Io.

${ }^{3}$ Russell's Collections and Recollections, p. $7 \mathrm{I}$.

- De Imitatione Christi, p. 7.

'Orr's Christian View of God and the World, p. 75. 
ideal organ of authority in religion must be found in the soul of man, in that secret place of its life where the voice of God is heard. ${ }^{1}$ If the Most High speaks to men at all, then the word which He says must be true, and the interpretation of His message which the conscience makes for itself, however confused and broken it may be, must become, for the individual, in the fullest sense authoritative. No man can deny the voice in his own conscience, or get beyond the assurance that

\footnotetext{
"Was die innere Stimme spricht

Das täuscht die hoffende Seele nicht."
}

"The authority of God manifests itself to the devout conscience as a revelation, a word of God; and this word holds in subjection the spirit of the man who hears and understands it; it is the truth which holds sway over the reason, the commandment which rules the will, the inspiration which exalts and enraptures the whole soul." ${ }^{2}$

From the purely speculative standpoint, then, the matter seems beyond dispute. Whenever we confess the existence of God and of the soul, and assert, further, that these are in

${ }^{1}$ Frank's System of Christian Certainty, pp. 6-12.

${ }^{2}$ Sabatier, Religions of Authority and the Religion of the Spirit, p. 257. 
communion the one with the other, we have reached the ultimate of religious authority. When we think of these two "luminous, selfevident Realities," we have to say that beside them there is none. The only real temple is the place where they meet. Compared with their mystical fellowship there is nothing holy and nothing pure. Here is the Power within all power, and here is " the Voice amid the voices."

\section{Objections to this Theory}

The issue, then, is thus far clear. The argument in favour of this theory is irresistible, so long as we confine ourselves to the region of speculative thought; but difficulty immediately arises when we go on to apply this principle to the actual facts of religious life and the accepted articles of the Christian Faith. It seems, then, to give a value to the individual conscience, as a medium of revelation which is not warranted by experience, and to be unable to explain the practical dependence of ordinary men on external influences. We see that the knowledge of spiritual things which comes directly to any soul is but a small part of that soul's treasure; we remember that every religious experience is largely the creature of environment; we recognise how impossible it is to separate any individual spirit from the 
great current of religious tradition which flows about its life. We study the Old Testament, and feel how little has been learnt of the secrets of devotion since the Hebrew Psalmists spoke to God; we read the Gospels, and marvel as we realise that we have gained nothing in the knowledge of the Father since Jesus preached in Galilee. As we consider, also, the records of Revelation, we cannot fail to see how much of the message of the prophets came to them, not immediately as a voice in their hearts, but indirectly through outward experience, tradition and influence. Reviewing, further, the story of the Christian Church, we have to confess that no small credit for the widening and deepening of her thought and aspiration regarding God and man has been due to the labours of science and the weary toil of philosophers and Humanitarians, and even to the activity of thinkers whose conclusions have been hostile to the entire system of Christian Faith. Finally, our knowledge of life, and of the average person, inclines us to hold in derision the thought that every man is his own pope, that the solitary conscience is the august seat of ultimate power, that the ordinary mind can be seriously regarded as any considerable medium of divine revelation. And, in view of all these 
things, some are disposed to say that the theory which finds the Organ of authority in the soul, however tempting as a speculation, yet fails to meet the facts of religious life and history.

Now, it is evident that this objection, were it valid, would be fatal. A theory which does not cover the facts of the case is one which is not true. And so, if it be granted that the hypothesis suggested here is inconsistent with what we have seen to be the facts of authority, -if it be shown that our theory cannot admit the great historical powers which have proven themselves by experience,- - then it must be set aside as a thing that is discredited by the testimony of the religious consciousness, the very witness it seeks to exalt. It must, therefore, be our task in the remaining pages of this chapter to suggest some preliminary reasons for holding that the view of religious authority stated above can be presented in such a form as to cover the attested facts of experience, while conserving a speculative unity of thought. To this end it is necessary to show that the definition which describes the Organ of authority as the soul in communion with God does not involve a subjective or an individualistic view of religion, and that it does indicate the common element in all the Forms of Revelation. 


\section{(a) That it denies the Supernatural}

But before we consider these points, it may be well to notice an objection of ten taken to the position now maintained-namely, that it denies the supernatural. This is a criticism exceedingly difficult to understand. Martineau distinctly teaches that the relation of God with the soul is altogether supernatural. The spirit of man is itself above nature, and above nature also must the region be in which it meets with God. This is the teaching also of Pfleiderer, and all other exponents of a spiritual Theism. What meaning, then, attaches to the charge of anti-supernaturalism as laid against this theory of religious authority? It is not without reason that Martineau complains-"The whole purpose of the first book in my volume is to show that the religious authority is necessarily objective and supernatural; and my critics charge me with contending that it is purely subjective and natural." 1 One is, indeed, at a loss to see what can be meant by the terms "natural" and "supernatural" in this connection. What does "supernatural" mean? Does it mean "miraculous"? If so, how can it apply to spiritual relations? "Miracle" is a term that belongs to the ${ }^{1}$ Seat of Authority in Religion. Preface to 3 rd edition. 
realm of physical things. It means an apparent break in the action of the laws which govern the material universe, and has no appositeness at all as applied to the things of the soul. Personal immortality, for example, is from the physical point of view a miracle; but from the spiritual standpoint, the marvel would be if the soul were to die. When we are dealing with spiritual facts we are in a region where all is supernatural, but nothing is miraculous. Bacon, indeed, says, "For martyrdoms, I reckon them amongst miracles, because they seem to exceed the strength of human nature, and I may do the like of superlative and admirable holiness of life." But if we use the term " miraculous" in this senseif we mean by it, as applied to spiritual things, simply that we feel certain religious phenomena to exceed the strength of human nature and to be above the level of common experiencethen there is no one that does not believe in the "miraculous element" in Revelation. Man, considered as a spiritual being, does not belong to the natural order. $\mathrm{He}$ is not ruled by the laws that bring to life and bring to death. $\mathrm{He}$ is a son of the Highest, of the same substance with the Father. And the place where he meets with God and hears His voice must ever be regarded as in the 
strictest sense within the supernatural sphere, above the reach of time and change-a house that is not made with hands, eternal.

\section{(b) That it involves Subjectivism}

Having noticed this preliminary objection, let us ask whether the theory before us involves a pure subjectivism, or leads to the denial of any real authority outside the individual life. Now it may seem as if this charge of subjectivism pointed to a weakness in our position. Certainly the case might be stated in such a way as to involve the absurd conclusion that the ultimate authority for every man in actual life is just his own opinion, that he legislates for himself, that he obeys no master and is captain of his own soul. But a statement that lent itself to such an understanding would be, not an exposition but a caricature. If we were to say that the soul, or the conscience, is the Source of authority, then indeed we would be affirming not only subjectivism, but atheism as well. The mind of man would then be its own lawgiver, its own master, its own God. But if we say that the soul or the conscience is, not the Source, but the Organ of authority, we are affirming in the clearest way the objective nature of all revelation; we are saying that the conscience 
is an inward witness to an outward reality, that the soul delivers that which first also it received. Dr. Wace, in his Boyle Lectures, gives us a singularly subtle and a true analysis of conscience, showing that it not only bears witness to the general supremacy of a righteous law, but also searches and tries the heart, and deals in mysterious justice with the personal character-making allowance for individual difficulties and weaknesses, meeting a man at every turn and every instant of life with the particular warning and guidance he needs. In short, the result of Wace's analysis is that conscience presents the character, not of a general law, acting without regard to the individual, but of a personal influence, intelligent and adaptive-not a "power" but a "person " making for righteousness." To the same effect is the striking saying of Martineau : "The consciousness of authority is doubtless human, but conditional on the source being divine." If this be true, then the experience which we call "conscience" is not subjective merely; it is the experience of a personal relation to a personal authority.

In like manner, it is plain that no religious experience whatever can be a merely subjective one, even although it seem to be out of relation 1 Wace, Boyle Lectures, pp. I97, 198. 
to an historical authority. Prayer is always a conscious communion with One not ourselves ; and no fresh conviction of $\sin$ or new understanding of duty or access of devotion ever seems to us wholly a discovery of our own, or a thing which has its origin in our own lives, or is but a communing with our own souls. There is ever the sense of receiving, of light shining in from beyond; there is always the "I" and the "Thou." No religious writer professing Theism denies this. Even Emerson, who came so near to pure Pantheism, distinctly admits the objective element in religion. His essay on the "Over-soul" clearly shows it ; and even the poem which contains the saying,

"Out of the heart of Nature rolled
The burden of the Bibles old,"-

contains the correcting thought :

" One accent of the Holy Ghost

The heedless world has never lost."

It seems, then, that even if the teachers of the doctrine of "the inner light" sometimes deny or underestimate the value of historical revelation, they still cannot be fairly accused of pure subjectivism. It is never asserted that man discovers truth for himself; but, on the contrary, earnestly affirmed that 
God reveals Himself to the soul, and that apart from this action of God there could be no religious life or knowledge of $\mathrm{Him}$ at all.

\section{(c) That it involves Individualism}

It may still be, however, that the further charge of individualism lies against the theory that the organ of authority is the religious consciousness. That theory may seem to involve an underestimating of our dependence on the witness of the prophets and the Church, and an asserting of the individual conscience and its claims above, and even in opposition to, all other influences. It may appear to elevate the ordinary man to a position of spiritual power rivalling that of the saints and sages. "Why," it may be asked, "should I acknowledge any external lord or master in spiritual things, since the Voice of God is in my own soul and is nearer to me there than it can be in any other soul, be it of Prophet or of Christ?"

A comprehensive attempt to answer this question must be left to succeeding chapters; only the sketch of a reply can be presented here. But surely we must bear in mind that when we affirm the soul in communion with God to be the Organ of Revelation, we are speaking only of that which 
is ideally true; we are not making any assertion as to the actual experience of the individual. We say that there is no revelation apart from the Voice Divine, speaking through a human spirit, but not that wherever you have a human spirit, there you have a revelation. We maintain, indeed, that every soul is a potential organ of authority, but we do not deny that many souls are potential organs only. We are sure that God speaks to every man, but we are persuaded also that in most men, by reason of human infirmities, His voice is faint and low. It is clear to us that in every personality there is the same spiritual sense that was in St. John and St. Paul, but it is not less certain that this spiritual sense in all but a few depends for its quickening on voices from without. God will speak to all of us; but He can speak to most of us only as our hearts are stirred, and our spiritual understanding enlightened, by the message of a Gospel that had to be uttered at first through choicer souls than ours.

These admissions we must make; and there are no theoretical difficulties in the way of our conceding them. For the witness of God in every heart does not exclude the superior authority of that same witness speaking through specially endowed natures. 
We have all some capacity of poetic feeling, but that does not affect the truth that to the writings of the poets we owe the melodies of thought. There is no doubt that we are of the same nature as Shakespeare, and possess the same faculties; but this does not annul the authority of Shakespeare within his own domain. Nor does it follow that because we are of the same stock as Milton, therefore we can all by development become Miltons. Dante could not appeal to us if we were not akin to Dante, nevertheless it remains true that we cannot evolve from our own consciousness critical canons by which to judge Dante. Such great spirits lay their authority on us. They judge us; them we do not judge. In like manner, the possession of a spiritual nature of the same kind as that of the prophets, and the actual enjoyment of communion with God, and the potential presence of the ultimate Authority in our hearts, - all this is not able to change the truth, nor is it hostile to the admission, that we are dependent upon the Prophets, that without them we should be living in a chill twilight of the soul, and in sad starvation of the spiritual man. It is the way of God to centre the universal light in select natures. While $\mathrm{He}$ reveals Himself to all, 
as they are able, yet the glory of His power He shows in one or two.

But if we thus admit the authority of the prophets, we may also accept that of the Church, the community of religious men. If I may be relatively dependent on the light given to my conscience by the revelation granted to more gifted souls, I may also be indebted to the voice of the Church in so far as it expresses the result of universal Christian experience. In point of fact, we owe more of the content of our religious life to the mediation of the Christian Society than we can ever know. Its tradition spoke with authority to us while as yet our souls had not learned to pray. Its worship was a fact to us before we had any worship of our own; our knowledge of Christ is mediated to us by Church testimony in the New Testament, and in the present life of the fellowship of believers. But this is by no means destructive of the position that the seat of Authority remains ideally in the soul at the point where it meets with God. The impression made on the disciples by Christ was an impression made on their religious consciousness; the witness which they have transmitted to us as to the nature of that impression is still the witness of their own 
hearts; and whensoever we come to share in their vivid sense of Christ, it is that their testimony has appealed to our minds in such wise that we stand in the relation to Christ that was theirs. The religious environment in which we find ourselves is the product of consciousness; it is the common element in the experience of believers; it is, in the truth of it, Christ speaking to us through the conscience of the Christian ages.

This theory seems, then, able to admit, and to explain, in full degree the authority of the Prophets and of the Church. Every word spoken by the Prophets was first of all a voice in their own hearts. The testimony of the Church, in so far as it is true and of universal authority, is but the voice of a choir innumerable singing a melody that was first heard and learned in the secret places of lonely souls, but a melody also which every age has rediscovered for itself. The authority of Prophets and Church alike is but a form of the same power that speaks, in accents dim or clear, in every heart.

\section{Relation of this Theory to the Authority of Christ}

There remains to be noticed the question whether this theory is able to make full ac- 
knowledgment of the Lordship of Christ. It is to be admitted that many of its advocates do fail to satisfy the consciousness of the Christian Church in this matter. When we turn from Martineau's book on the subject under discussion to Herrmann's Communion with God, we feel that the Ritschlian has grasp of a truth that has escaped the Theist. ${ }^{1}$ We do not say that Herrmann's analysis of the consciousness of Christ is more beautiful than that of Martineau, or reveals more of a personal devotion to our Lord. But we find in the one what we miss in the other, a full assertion of the personal authority of Jesus. Martineau shrinks, with all his school, from admitting the claim of Jesus on the allegiance and trust of men. In his view it is the religion of Christ, not Christ Himself, which is to be regarded as having authority. He will not believe, for instance, that our Lord uttered the great appeal, "Come unto $\mathrm{Me}$ all ye that labour," on the ground that it strikes a note of undue self-assertion. And this failure to admit that element of personal authority in the attitude of Jesus, which Herrmann so justly emphasises, being characteristic of Martineau's school,

1 Verkehr des Christen mit Gott, Kap. ii. pp. 68-75; Eng. trans. (The Communion of the Christian with God), and edition, pp. 84-93. 
seems to suggest that the theory which finds the seat of authority in the soul logically involves a denial of the personal Masterhood of Christ. We may, however, take leave to doubt whether this timidity in asserting the Authority of our Lord, which admittedly characterises this school, is a necessary part of their position. Dr. Rainy says, most suggestively, "It might be a question whether Dr. Martineau's theory of authority in itself absolutely excludes all the elements in Christianity which he rejects." ${ }^{1}$ Following Dr. Rainy's hint, we may ask whether Martineau's theory does not logically imply a higher view of the authority of Christ than he asserts or than his theological position as a whole will allow him to admit. If it be granted that the testimony of consciousness is authoritative, and if it be further allowed (as it is) ${ }^{2}$ that we are dependent relatively on those to whom God has specially revealed Himself, then on what ground is the witness of the Christian consciousness to the Lordship of Christ denied? And why should it be counted incredible that the universal Authority may have taken a perfect historical form? If

1 Critical Review, vol. i. No. I, p. Io. See also Stanton's Place of Authority in Matters of Religious Belief, p. 33.

${ }^{2}$ Seat of Authority in Religion, p. 308. 
there be one thing to which the Faith of Christendom has continued throughout the ages to bear unswerving witness, it is the sense of dependence on Christ. What good reasons can be advanced for rejecting this testimony? Since the prophetic function is admitted to be indispensable, why should there be any desire to deny the claim of Jesus to possess an authority of which the prophetic power is the imperfect type? If the revealing activity of God concentrates itself in select souls, why should there not be One in whom it dwells completely? If, again, it is true that the conscience is the witness of God; and if it is also true that every conscience is an imperfect revealer, a glass that, in reflecting, distorts-a medium that renders indistinctly the voice of God,- -then, are we not led to expect the appearing of this witness in a perfect form? Do not all the broken revelations point to one that is complete? Do not all the shadowed lights imply one in which is no darkness at all? The perfect conscience, and therefore the perfect organ of revelation, can only be a soul entirely possessed of God. But if this be so, why should we refuse the testimony of the Christian Church that Jesus is this complete revelation, that $\mathrm{He}$ is this typical Conscience of the race? And if $\mathrm{He}$ 
is these things, then what shall be the measure of His authority? Shall we not expect to find in Him that accent of command that is in every voice of conscience everywhere? It does not seem logical to set so great stress on the testimony of conscience and yet refuse respect to that testimony as the voice of Christian experience bearing witness to the supremacy of Jesus. Nor does it seem reasonable to hear in every heart the broken word of God, and yet to deny that this word may have been spoken perfectly in one spotless soul. But if these things be admitted, the recognition of the personal supremacy of Christ cannot long be truthfully withheld.

\section{VI.}

It thus appears, from the point of view of this chapter, that the doctrine of religious Authority which alone seems to have speculative validity and to reach any unity of thought, may also be so stated as to escape the charges commonly laid against it, and to cover all the facts of experience and satisfy the demands of historic Christianity.

Perhaps the position might be tentatively put in some such way as this-Religious authority is found wherever conviction arises in the soul such as to carry with it the assur- 
ance that it is of God. This conviction may be created in three ways : (I) by direct revelation to the individual conscience in which it is found; $(2)$ or by a message conveyed to that conscience through a specially endowed soul, and recognised by it as true ; $(3$ ) or by a deliverance of the common religious consciousness, verified in the individual experience. Some such statement as this might be possibly found to cover all the phenomena of genuine religious authority, and to exhibit these as being all of one kind. It would admit the authority of the individual Conscience, the Prophet, the Church, and the Christ, while finding the common element in all these to be the voice heard in the soul in communion with God.

\section{The Test of Truth}

It may indeed be urged that such a statement supplies no standard by which to distinguish the true from the false in religious belief. . Things have often been earnestly accepted as revelations of God which yet have not been true. How are we to discriminate, then, between genuine and spurious forms of religious authority? To what standard can we appeal in the conflict of opposing faiths? But the answer to this must surely be that there is no real test of truth except experience. 
The soul may sometimes mistakenly suppose that it has received a word of God, and it must often, through its weakness, render a real message in poor and erroneous forms; and the only appeal is to life, to the testimony of the common consciousness. If any professed deliverance of religious authority is ever wholly false its true nature is soon revealed : it fails to find any lasting response in the hearts of men, and dies. If any religious message, seeming to us to be false, yet survives and holds the loyalty of many generations, then it must be relatively true; the idea which it contains, when separated from its dogmatic or material form, must surely be of God. That idea must, at least, have been the best interpretation which the consciousness of him who heard it was able to make of the voice of the Most High. It must have proved itself in experience to be capable of "comfort, counsel, and the words that make a man feel strong." Whenever a higher message is given, more suited to the wants of men, the lower gospel will lose its power and pass away. The voice of God will be interpreted more clearly at a higher stage of consciousness, and will prove itself in a richer life. "When that which is perfect is come, that which is in part shall be done away"; but the test of perfectness is experience. 


\section{Possible Conflict of Authorities}

It may be further objected that we are still really making the individual conscience the only authority; that we deny any objective standard of religious truth to which a man ought to bow, whether he sees it to be true or no; that we assert even the Lordship of Jesus to depend on its being accepted by the individual heart,-implying that no word of His is to be held as authoritative by a man until he has himself tested and proved it. And this objection undoubtedly raises one of the most difficult of the many problems which surround this whole subject.

It is to be remembered, however, in the first place, that this difficulty in adjusting the relation of "inward" to "outward" authority in religion is not peculiar to any particular theory. No theology teaches that a man is bound to accept everything that is laid down by Church or prophet, just as he may accept police regulations, without reference to his own conscience or heart at all. It is everywhere admitted that the tribunal of the soul has inalienable rights, and that mere formal assent without inner conviction is wanting in full religious value. This being so, it follows that the difficulty of stating clearly how far 
the individual ought to defer to authority which he has not himself tested is a burden which rests on no one school alone. If you admit the claims of the conscience, and also of Christ, or of Church, you must have trouble in adjusting the relations of these powers, the one to the other.

Waiving, however, this merely negative point, we may proceed to suggest that the position stated above does not require us to reject or ignore such authorities as we have not in our own experience proved; it rather requires us to hold them in high respect, and to recognise that our real dependence on them must be far greater than we know. But it does lead us to assert that these are not yet of full religious power for us. We are required, in short, to keep in mind that the influence of these historic witnesses over the individual is of two very different degrees. In the lesser degree this influence is mainly intellectual, regulative, outward ; in the greater, it is spiritual, inspiring, inward. The lesser degree of influence is wielded by all such utterances of Prophet, Church, or Christ as our own hearts have not yet felt as true. We do not deny the objective authority of these; we recognise it as a fact in the lives of other men. We regard these utterances with reverence; since we know that they have 
received the "amen" of the Christian Community, whose consciousness is larger and deeper than ours. The same reasons which lead us to respect the convictions of our own minds lead us to hold in deference those of the Church. Believing that the prophets are specially endowed souls, we reasonably distrust such voices of our hearts as seem to contradict them. Holding that Jesus is the perfect revelation, we rightly conclude that in matters of moral and spiritual truth it is not to be supposed that we are right and $\mathrm{He}$ is wrong. Receiving the testimony of the Christian conscience to the Lordship of Christ, we affirm in theory that all His thoughts are true.

\section{Outward and Inward}

To this extent, then, we are logically bound by our position to hold in deference all attested deliverances of the religious consciousness. To this degree all utterances of historic authority have power over us, even if our own hearts have not approved them. But this is not, in the strict sense, for $u s$, a full religious authority. It is a matter of mental deduction rather than of immediate conviction. It cannot reveal to us the inmost reality, or inspire to gladness of worship, or lead a victorious march on the way of the will of 
God; it has no charm to cool the fever of our souls nor sovereign touch to quiet our unrest. This full religious authority belongs to such things only as have received the sanction of a man's own heart, and have come to speak no longer from without but from within. The spirit knows no master who dwells altogether outside itself. The utterances of revelation lose their character of outwardness as they increase in power; and, in their fulness of religious authority, are indistinguishable from the voices of the soul. When St. Paul uttered his hymn of divine love he spoke as out of the deep places of his own spirit; the outer and the inner light for him were one. In his best hours, also, it seemed to him that his mind and the mind of Christ were wholly reconciled. "I live, yet no longer I, but Christ liveth in me." It is ever so. The greater the degree of religious authority the more completely are the voices of the soul and of its Master made one in the unity of faith.

"A little while there was of Thee-and-me, And then no more there was of me-and-Thee."

\section{X. "God in Nature"}

A singular confirmation of this whole position as to religious Authority is found when 
we analyse the experience of those who discover a revelation of God in that most external of all witnesses, the natural world. It is the common testimony of poets and saints that such a revelation exists. To the ear of the Psalmist the heavens declared the glory of God; Jesus saw in the lilies of the field and the birds of the air signs of His Father's love; the Apostle was sure that God made plain through the things that appeared $\mathrm{His}$ eternal power and divinity; to the tender gaze of St. Francis all the creatures of the lower world seemed kindred of his in the love of the common Creator; Wordsworth felt in Nature a Presence that "disturbed him with the joy of elevated thoughts," and declared that "one impulse from a vernal wood" could teach him more . . . "of moral evil and of good than all the sages"; Emerson bids us see in outward things-

\section{"Pictures of time,}

That fade in the light of their meaning sublime";

Aristotle believed that if men were to behold the wonders of the world for the first time, with fresh eyes, they would see in them the certain proofs of Deity-would say "there are gods, and these are the works of gods."

And if such be the testimony of poets and saints, it is not less that of the average 


\section{06 AUTHORITY IN RELIGION}

religious mind. If there be anything that seems certain to the common understanding of the devout, it is that the natural works of God are clear evidences of $\mathrm{His}$ wisdom and power and love. The simple of faith are always implicitly conscious of the Father when they are touched by the loveliness of the world; and for them the perception of natural beauty is one with the sense of the beauty of God. The outward Universe by its ministries of sublimity, awe and grace, is certainly a prophet of hope and comfort and peace to the great multitude of the pure and devout in heart. And among ordinary religious people there are more than we sometimes think who are able at least to understand the witness of the poet:

"In such access of mind, in such high hour Of visitation from the living God, Thought was not; in enjoyment it expired. No thanks he breathed, he proffered no request; Rapt into still communion that transcends The imperfect offices of prayer and praise, $\mathrm{His}$ mind was a thanksgiving to the Power That made him; it was blessedness and love."

But what does this witness prove? Does it show the existence of a purely objective revelation of God in Nature, able to impose itself on the mind, apart from faith or the testimony of the inner voice? Not so; else 
would every naturalist be a worshipper, every astronomer devout, every poet a saint. The outward Universe does not, of necessity, make any religious impression as it presents itself to the understanding; rather does it sometimes appear to deny the teaching of Christ. John Stuart Mill found reasons in Nature for the denial of Theism. Professor Clifford testified that after years of scientific study he came at last to "look up to the heavens and see no Father there." Darwin saw no proof of God in the things that he observed. The ordinary irreligious person, also, perceives as little of divine meaning in the Creation as he does in a bridge or a steamship or a telegraph. It is only by the witness of the spirit in the heart that you recognise the Spirit in the world; it is " the god within that enables men to understand the God without.' If by any means the organ of revelation in the soul is not able to speak, or is misunderstood or ignored, no Divinity will be discerned in the heavens or the earth. The Psalmist heard the heavens declare the glory of God, because he heard his heart within declare the law of God. Jesus beheld the Father in Nature because He knew the Father in secret. Wordsworth saw God's dwelling in the setting suns because he saw it also in the mind of man. 
The devout of heart discern divine meanings in things that are seen, because they have first had that inward faith which beholds the invisible. The religious authority of Nature, in short, does not exist except as a part of the religious authority that is within the Soul.

A great Quaker writer has expressed this truth with singular tenderness and beauty. Speaking of the voices within the heart, he says: "Thus the man who is attentive to these divine notices sees the animal, the vegetable, and the planetary world with spiritual eyes. He cannot stir abroad but he is taught in his own feelings, without any motion of his will, some lesson for his spiritual advantage; or he perceives so vitally some of the attributes of the divine Being that he is called upon to offer some spiritual incense to his Maker. If the lamb frolics and gambols in his presence as he walks along, he may be made spiritually to see the beauty and the happiness of innocence. If he finds the stately oak laid prostrate with the wind, he may be spiritually taught to discern the emptiness of human power; while the same spirit may teach him inwardly the advantage of humility, when he looks on the little hawthorn which has survived the storm. When he sees the change and fall of the 
autumnal leaf, he may be spiritually admonished of his own change and dissolution, and of the necessity of a holy life. Thus the spirit of God may teach men by outward objects and occurrences in the world. But where this spirit is away, or rather where it is not attended to, no such lesson can be taught. Natural objects, of themselves, can excite only natural ideas; and the natural man looking at them can derive only natural pleasure, or draw natural conclusions, from them. In looking at the sun he may be pleased with its warmth, and anticipate advantage to the vegetable world. In plucking and examining the flower, he may be struck with its beauty, its mechanism, and its fragrant smell. In observing the butterfly as it wings its way before him, he may smile at its short journeyings from place to place, and admire the splendour upon its wings. But the beauty of the Creation is dead to him, so far as it depends on connecting it with the character of God; for no spiritual impression can arise from any natural objects, so that these should be sanctified to him, but through the intervention of the Spirit of God." 1

${ }^{1}$ Clarkson, Portraiture of Quakerism, vol. ii. p. ${ }^{4} 6$. 


\section{THE AUTHORITY OF THE PROPHETS}

\section{-THE ARISTOCRATS}

\section{I.}

THE method of God is aristocratic. He gives His light and conveys His gifts to the world through chosen men of power. Philosophy, the knowledge of life as a rational whole; Science, the understanding of the laws and facts of the natural world; Literature, the criticism and portrayal in seemly and ordered words, of human thought and experience ; Art, the exposition of beauty in form and colour and sound;-all these have for their servants and apostles specially endowed men, gifted spirits, Aristocrats. The multitude originates nothing in literature or science or philosophy or art. It responds, it admires, it supports, it stimulates-but it does not create. The makers, the messengers, the discoverers, are ever a small selected band. Why this is so we cannot say; we only know that such is the 
fact of the case. Doubtless the Almighty could have made us all philosophers, artists, musicians, poets ; but doubtless also $\mathrm{He}$ has not done so. The gifts and powers which $\mathrm{He}$ has not wholly denied to any of us $\mathrm{He}$ has yet given to a few in so eminent a way that they seem to form a race apart. The difference between the average man and Keats or Shelley, in point of poetic gift, is only perhaps a matter of degree; but who can measure the degree? The ordinary person has a sense of music and also of colour and form; but the ordinary person will not become a Wagner or a Rubens, though he live a thousand years. We all possess something of the mind that was in Shakespeare; but time contains no magic that can change us into Shakespeares. Between the Democracy and the Aristocrat there is a great gulf fixed. Some men are our Masters by right of birth; and we know that 'mid all the wondrous changes of all the coming times they will still retain their royalty; they "will still be the elder-born."

It is not, of course, to be forgotten that the great man is not a self-dependent, miraculous creature, emerging suddenly out of the unknown, wholly inexplicable; owing no debt to his surroundings or to the multitude or to the past. You can generally find for him some 
sort of spiritual ancestry. His powers are stimulated by something in his environment. $\mathrm{He}$ enters into the labours of lesser men and reveals the thoughts of many hearts. $\mathrm{He}$ is the child, as well as the master, of his age. He sometimes appears as a lense that concentrates into a great light many scattered rays, or as a voice that utters at last the long results of time. Doubtless, also, it is true that the greatest man is he who helps others to be great, who brings them into bondage only that he may bestow on them a larger freedom. " $\mathrm{He}$ is a monarch who gives a constitution to his people; a Pontiff who preaches the equality of souls, and releases his servants from their barbarous homages; an emperor who can spare his empire." 1 Still the genius of the Master-man has ever in it something individual, personal, mysterious. It yields its secret to no analysis : you cannot by searching find it out: it belongs to a world of wonders : it comes of that Kingdom whereof is the Spirit that bloweth where it listeth. It is the ultimate gift of God.

"Ever their phantoms rise before us, Our loftier brothers, but one in blood. At bed and table they lord it o'er us With looks of beauty and words of good."

But this aristocratic element is just as clearly ${ }^{1}$ Emerson, Uses of Great Men. 
a feature of the Divine Economy in the sphere of religion as in other realms of human thought and life. Revelation delivers its great words through an order of chosen menProphets, Apostles and Saints. It is almost as true in spiritual things as in matters of Art, Literature, Science and Thought, that the common mind is not creative. ${ }^{1}$ It assents to the message of the Masters, tries, proves and elaborates it, enriches it by experience, applies and develops it,-but does not deliver a message of its own. "The burden of the Bibles old" was uttered by Saints and Seers. The Hebrew and the Christian Scriptures are the Record of the Aristocrats. It was not to the weary multitudes of India, but to the lonely soul of Sakya Muni that there came the message of the Paths of Peace. It was not to the general conscience of the Arabian tribes, but to Mohammed alone, that there was given the thrilling word of emancipation and austere power, "There is no God but God." The suffering people of captive Judah would never have learned for themselves the divine meaning of travail, had there not been a Prophet to speak of the man of sorrows and acquainted with grief. The revelation of God in human life was not discerned by common

${ }^{1}$ For necessary qualification of this, see infra, pp. 131-132. 
eyes until the Masters of Faith had said, "Like as a father pitieth his children," and had spoken of "The bands of love and the cords of a man." ${ }^{1}$ The glory of Christ and the power of the Cross had never been known to the world but for the spiritual genius of a few men-Peter and Luke and Paul and the Evangelist John. At this present day also, how dependent are we, not only on the "Classical pages of Christian tradition which we call the Scripture," not only on Prophets and Apostles, but on the lesser power of Saints and Reformers-of Augustine, à Kempis, Calvin, Luther; on those also who composed our Litanies, wrote our Hymns, framed our Creeds; on the artists who rendered in colour the sacred traditions of Faith, and the musicians who interpreted Christian thoughts in the manifold glories of sound.

Now, it is evident that those whom we call the spiritual Aristocrats are of various orders and kinds of power; and that the highest degree of authority is that of the Prophet, the man who is conscious of a direct revelation received from God and a direct message to give to men. But it is no less certain that the word even of the greatest Prophet contains

${ }^{1}$ Cf. Professor George Adam Smith's Book of the Twelve Prophets, chapter xxiii. 
elements of differing worth. No one will attach an equal value to all the utterances of Isaiah or to all the chapters of Romans. Every Prophet has a Word that appeals with power to the universal religious consciousness, but he also has words that reach the heart of few. There is something in his Gospel that endures, and something that perishes. There is an element in his teaching that is of pure spiritual authority, and another that is of force only as it is able to commend itself to the logical understanding. How do we account for this feature of the Prophet's work, and how can we distinguish the greater element in his Gospel from that which is less? The answer to this may perhaps be found by an analysis of the experience in which the prophetic message has it birth. That experience begins in trial or effort of some kind, leading on to spiritual searching and travail. After this there comes a revelation, - an immediate consciousness of a great truth, a sense of a marvellous light shed in upon the soul. Then, this revelation assumes the form of a Gospel to be spoken out to the world. Finally, the Gospel becomes the subject of reflection, of argument-a thing to be analysed, and justified to the reason, and applied to the facts of life. These four stages may be shown to belong to 
the story of every prophetic experience-(I) toil and labour, (2) illumination, (3) proclaiming, (4) reasoning.

That this is a generally true analysis may be proved by reference to the experience of great religious messengers, both without and within the Hebrew-Christian sphere.

Sakya Muni, touched and stirred by the infinite sorrow and weariness of life, spends days and years in fasting and poverty, and strenuous effort of mind and soul. At length there comes to him of a sudden, as he sits beneath the sacred tree, a great light, a vivid sense of a sure and certain way of freedom. Then his conviction becomes a Gospel, ${ }^{1}$ a message to be preached, with burning heart and eloquent lips, to the multitudes of India. Combined with this, also, there is a process of half-conscious philosophisings, of rational elaboration, of adapting the message to the forms of Hindu thought. ${ }^{2}$

Mohammed travelled the same road. In the first stage of his experience he might have

${ }^{1}$ Cf. Prof. Menzies, History of Religion, p. 364 .

2 Cf. Arnold's Light of Asia, Book viii. This fourth stage was, however, in the case of Buddha, mainly the work of his disciples (see Menzies, p. 363); cf. also chapters on Buddhism in Freeman Clarke's Ten Great Religions. Much material of great value, both as to Buddhism and Mohammedanism, is to be found in the Report of the World's Parliament of Religions. 
used the words of the Psalmist, "My tears have been my meat day and night, while they continually say unto me, Where is thy God." The condition of Arabia was a burden to him -its political divisions, its lawlessness, its idolatry and manifold distresses. His own religious nature, also, was profoundly unsatis fied, disturbed with the sense of the presence of One not seen nor understood. And the issue of this inward and outward trouble was lonely vigils, wrestlings and tears. But out of this travail and sorrow came at last the Revelation, the vision of the spiritual Reality. And then Mohammed was a prophet proclaiming, to all who would hear, the gospel of the clear-shining Unity of God. After this there came a fourth stage of dogmatic and practical application;--unfortunately also, a period of decline and weakness, - of defending his mission by doubtful tales and applying his message in doubtful ways.

When, further, we leave the annals of nonChristian Faith and come to the records of Scripture, we find that an analysis of the prophetic witness yields the same result. The most perfect type of the spiritual Aristocrat is the Apostle Paul ; and what are the elements of his experience? A long time of battle and effort and spiritual strife; then a great 
mystical revelation; then an intense passionate preaching of his gospel ; and, lastly, mingled with this, a logical explanation and defence of his message, an elaborate systematic apologia. And the case of Paul is a classical instance of the prophetic experience. The way he trod was that of the messengers who had gone before him and of those who were to follow after. Certainly Augustine and Luther knew every step of his journey. Theirs also was the long struggle, the illumination, the gospel, and the reasoning. They also learned how hard it is to kick against the pricks; they too heard unspeakable words which it is not lawful for a man to utter; they also felt that it was woe to them if they preached not the Gospel ; they, as well as Paul, held scholastic discourse of theological forms and plans, of "fate, free-will, fore-knowledge absolute."

\section{II.}

Now, if this be a true account of the experience of the Prophets, we discover the secret of their power and also the reason for the elements of differing value which are found in their work. Of the four stages in the mission of the Seer, one only presents a feature peculiar to himself - that is, the stage of illumination, of intense immediate convic- 
tion. Multitudes who are no Prophets have sorrow and travail of mind and heart, preach a gospel, and reason about the things of faith. But only the Prophet has the overwhelming "sense of being possessed," the direct intuition, the wonderful assurance of personal authority by the grace of God, which we call Revelation. It is the power of having this experience that separates him from common men. His peculiar glory is not that he can reason, can suffer, can speak; it is that he has seen. He has had a message which could only be described "as the coming forth of a Light ; it was not the Light of an outward sun; it must be the Light of which that which is gathered up in that of outward suns is the image. It was not a bodily eye which received this Light; but it was an eye; you could give it no other name. God Himself must have opened it, that it might behold Him ; in His light it saw light." 1

But if this be the peculiar gift of the Prophet, it follows that his authority depends on it and on nothing else. His proper power is confined to the sphere of the talent that has been given him; it does not in its fulness extend to other realms of thought and life. When he is declaring the religious truth

${ }^{1}$ Maurice, Prophets and Kings of the Old Testament. 
which first also he received, he is a Master and King, and compels the assent of men-"he lords it o'er us with looks of beauty and words of good." But his authority is less when he speaks, not as the Seer but as the logician, when he appears no longer as the Preacher of a faith but as the expounder of a theology. It is one thing to be able to receive a revelation, and quite another to be able to defend and explain it and apply it with certainty to the facts of life. And the seer is not, any more than the poet, gifted of necessity with the powers of logical statement and systematic definition. His gospel is divine and bears its own witness; but his logic is as the logic of other men. When he tells of the pain and travail that came before his revelation, he impresses the mind and heart; when he speaks of his vision and declares his message, he is clothed in majesty and spiritual power; when he proceeds to analyse his Gospel, and show its rational 'basis, and explain its bearings on practical life, he commands our deference, indeed, but is not beyond our criticisms-he is become almost if not altogether such an one as ourselves. The message of the Buddha was pure and righteous in its spiritual essence, being the gospel of Peace through Self-renunciation; but the later rational forms 
in which it was taught were unworthy of its greatness. The evangel of Mohammed was true and sublime in itself; but the reasoning of Mohammed was insignificant and his theology desolating. The Hebrew Prophets remain eternal teachers of spiritual truth; but their applications of their message to the circumstances and politics of the time are matters which are open to debate. The Apostle Paul had visions and revelations of the Lord; and the glory of his spiritual gospel is a bright, unsetting sun; but his reasoning about predestination, and his arguments regarding Hagar and Mount Sinai, and his speculations as to marriage and the position of women in Church and State, are not beyond the reach of question or secure against the hand of time. Luther had a great spiritual experience, so direct and vital as to give him a place among the Prophets; and his message that speaks of the blessedness of him who "casts himself on God" is true for "ever. But none the less the theology of Luther is within the range of criticism; and his inconsistencies of theory are not less certain than his unity of faith. ${ }^{1}$

${ }^{1}$ Cf. Harnack, What is Christianity? pp. 297, 298, also Dogmengeschichte (Eng.), vol. vii. pp. 238, 256 ; cf. also Acton's Essays on Liberty, pp. 157-168. 
We see, then, that the Prophet is not independent of his Age, inasmuch as his revelation comes to him always after his spiritual and moral nature has been awakened by the circumstances and needs and thoughts of his time. We see, also, that when he constructs a system of doctrine, or seeks to supply a rationale of his message, he is not clothed in the fulness of his authority; since reasoning and application are no necessary part of his peculiar gift. He does not always secure assent, and need not always be obeyed, in matters of philosophy and definition; but he always carries conviction, according to his degree, when he speaks of that he knows and testifies of that he has seen. The secret place of his authority is the place of his meeting with God-of the heavenly voice and the heavenly vision. Our Lord Jesus Christ who, being much more, was yet the supreme Prophet, spoke always directly ; He illustrated, commended, appealed, but $\mathrm{He}$ did not reason ; He did not prove God, but announced and revealed Him. "The only-begotten Son who is in the bosom of the Father declared Him."

\section{III.}

But if the authority of the Prophet be confined to his spiritual message, his evangel, 
what are we to say of his witness regarding the way in which his message came? Does the Gospel guarantee the apocalyptic and imaginative forms in which it is stated to have clothed itself? What are we to say about the vision of Isaiah, about the dream of Peter, about the experience of St. Paul who was caught up to the third heaven? Are we to take the prophets at their word regarding their wonders and signs, or are we to dismiss these as at the worst morbid illusions, at the best things of no value or meaning to us? This is a question to which, we may venture to say, no dogmatic answer should be given. Who shall assert that Isaiah did actually see seraphim, or that the Apostle Paul really was in the third heaven-seeing that we have no knowledge of seraphic regions and can attach no meaning to "the third heaven"? But who, on the other hand, shall say that there were no experiences of a wonderful nature corresponding to these descriptions of Prophet and Apostle? It is not well to make average knowledge the test of highest possibility. We are, none of us, able to say what imaginative and physical signs may accompany a great access of divine light shed suddenly on the soul. The spiritual universe is daily unfolding to us so much of mystery and wonder, the 
influence of mind on mind, without material medium, is so nearly an established fact, the mass of evidence in favour of certain mystical experiences is so great,-that sober minds will be slow to reject as incredible the marvels that are told by Seers and Saints. ${ }^{1}$ Why should the inner voice not sometimes sound so clearly as to be like an audible word? Why should the soul not sometimes hear a message with a distinctness that makes it indistinguishable from dictation? Why should uncommon men not have uncommon experience? Why should not Paul have heard unspeakable words, nor Isaiah have looked on supernatural glories? Why must we reject the testimony of Joan of Arc- "My voices have not deceived me!" It is easy to say that the belief in such things is absurd; but such an answer is only a calling of names. We wish to know why it is absurd. Martineau, indeed, tells us that the apocalyptic element in Revelation is of little value for us, since "only God can know if it be true." But seeing that the divine verdict is not within our knowledge, we may at least maintain suspense of judgment, and regard with reverence the witness of the great spiritual masters when they speak

${ }^{1}$ Cf. Frederick Myers' Persistence of Human Personality, etc., also James's Varieties of Religious Experience. 
of their own best experiences and their own highest hours :

"Oh sacred be the flesh and blood To which they link a truth divine." 1

But, however this may be, it is plainly true that the element of real authority in the prophetic message is its spiritual and moral burden. Apocalypse and vision appeal only to those who see them; but "spiritual power accredits itself." ${ }^{2}$ Its appeal is as immediate as light: "Its evidence lies simply in its existence as a power that lives and develops in the spirit of men." 3 The conviction of the Prophet has the quality of being able to reproduce itself in others; his revelation is able to perform a revealing work in common minds; his word awakens echoes in the universal heart ; his command approves itself in peaceable fruits of righteousness. "If he comes to me with the inspiration of a higher insight and the authority of a purer will ; . . if he shames me out of the doubts which hang around the lower mind by lifting me into the light of a more trustful love; I am sure of my-

I Tennyson, In Memoriam, altered-"To which she links a truth divine."

2 Bruce, Expositor's Greek Testament, vol. i. p. 265.

${ }^{3}$ Ed. Caird, Evolution of Religion, vol. ii. p. 171. 
self that he has spoken to me a divine word, -that I live in a light I never had before; that whether I know or not who $\mathrm{He}$ is and whence He cometh, this one thing I know, that whereas I was blind now I see." 1

While, however, we say that the word of the aristocrat has this immediate, selfevidencing power, we do not by any means assert that it is in its nature non-rational, or that our submission to it is incapable of theoretic justification. The prophetic message is able, in the end, to satisfy the mind as well as the heart; and, while it proves itself good to the obedient will, it conciliates at last the understanding too. The rationale of the Seer's authority is that the power of the Prophet is of the same nature as the power of that Conscience which is within us all. In the experience of him who receives a revelation there are only two great elements-God and the Soul. And these two elements are in every conviction of duty and every vision of truth and every impulse of good. The voice that spoke to Isaiah is the same voice that says in us all "this is the way, walk in it." The unspeakable words the Apostle heard were of the common language of the spirit. The light that lightened John was that which 1 Martineau, Seat of Authority, p. 318. 
lightens every one. The witness that speaks of a right and a wrong in the soul of the average man may be weak and humble, but still it is the witness of God. When, therefore, we obey the word of the Aristocrats we are obeying our own higher selves; we are welcoming a message which our own souls would speak, if only they were able. We are hearing a word our own spirits would discern, if only they were stronger. We are not receiving an alien rule, but the rule of our own kin, "our loftier brothers, but one in blood." The same law that constrains us to obey the voice in our heart constrains us to bow to the voice of Jesus. Denying the best that is in the Master, we deny the best that is in ourselves.

The rule of the Aristocrats, then, is a part of the divine Economy; it is rational, it is imperative. Their inspiration is so much greater than ours as to be practically of a different order. We are dependent on them for the light of our seeing and the bread of our life. Yet their authority is that of elder brothers, and kings of our own race. The "promise and potency" of the power that is in them is in us all. They have no gift that is not hid in every soul. And their office is to raise us to their own level, to bring us into 
their own light; so to teach us that we shall need their masterhood no more, so to help us as to make us Kings and Priests, with them, to God. "After those days, saith the Lord, I will put my Law in their inward parts, and write it in their hearts; and will be their God, and they shall be My people. And they shall teach no more every man his neighbour, and every man his brother, saying, Know the Lord: for they shall all know $\mathrm{Me}$, from the least of them unto the greatest of them, saith the Lord." 1

1 Jer. xxxi. 33, 34 . 


\section{CHAPTER VII}

\section{THE AUTHORITY OF THE CHURCH, ${ }^{1}$ THE CHRISTIAN DEMOCRACY}

\section{Tradition}

WE have seen that the method of God in Revelation is aristocratic, that $\mathrm{He}$ conveys His Gospel through specially gifted men; but we have also to admit that $\mathrm{He}$ endows with great power and authority the common religious Conscience, the collective testimony of devout minds. Every voice must have a medium; and the medium of the prophetic voice is that spiritual atmosphere, that subtle environment, in which we live and move. When Luther delivered his message, he spoke to men who lived in the light of a common belief, and his Gospel was conditioned, as to its form, by the experiences and needs of the religious democracy. Saint Paul in declaring his

1 The "Church," throughout this chapter, is held to be the Visible Society, in all its historic branches, of those who "profess and call themselves Christians." 
Evangel employed the language and logic of his time. Our Lord Himself was singularly loyal to the traditions of His age-conforming to the worship of Synagogue and Temple, and speaking to the people by means of those inherited forms which they were able to comprehend. Buddha, also, in his teaching used the great dogmatic symbols of ancient Hindu thought. There is, in short, a spiritual atmosphere, a compelling medium, which surrounds every revelation, on which every revelation must depend for the means of reaching the individual heart and soul. This atmosphere and medium is the product of long ages; it is the resultant of many varying forces; it comes of thoughts that have been tested and tried over and over again, of experiences repeated in different lives, of customs slowly gathering force "from precedent to precedent," of conventions established by education and habit, " of old, unhappy far off things" and the dear traditions of the Fathers. This element in religious life and history is a thing of incalculable moment; one that, no doubt, contains matters of varying value, and that is liable to be despised by the theorist and reformer, but one also that, for good or for evil, largely determines the thoughts of us all. It constitutes in part the power of the Democracy. 


\section{Positive Power of Democracy}

But this common consciousness, this generalised experience of the religious mind, is not only an atmosphere through which the Prophet speaks to us; it is also an active force which develops, tests, enriches and applies the word of Revelation. The voice of the Christian Democracy does not merely repeat the message of the Aristocrats; it renders that message in words and ways of its own-in symbols and signs of the imagination, in varying forms of the understanding, in imagery and poetry of Faith. The corporate Conscience makes a liberal use indeed of its function as interpreter of the Gospel; for it silently drops and rejects such things in the Record of Faith as it cannot use or apply. Certain of the hidden things in Revelation it brings to the light, and certain other elements of letter and form it slowly robs of power. It is influenced from age to age by social and political surroundings, by the changing needs of practical life, by the scientific and philosophical teaching that from time to time prevails, and by the judgments of experts and scholars. It has also, we cannot doubt, a certain power not only of developing the message of the Prophets, but also of originating general con- 
victions of its own. For who is there that is able to trace the belief in Prayer or in the unseen Life to any source in the authoritative utterance of an individual soul? These great things rose and spread like a dawning light in the common heart of man. You cannot say of their beginning, "Lo here, or lo there." They were born of the spirit that "bloweth and is still."

\section{III.}

When we think more closely of the relation of tradition to the Gospel, we see that it sometimes develops and enriches the ideas of Revelation, but we recognise also that it is often a power to degrade and corrupt.

Who shall say that the forms of Christian worship are not richer to-day than they were in New Testament times? Who can doubt that the Gothic Cathedral, as compared with the early Christian meeting-place, does indicate a wealthier, greater thought of the meaning and majesty of prayer? Who shall question the advance made since the age of the Apostles in the application of Christian ethics to questions like slavery and poverty and the treatment of subject peoples? Surely, too, we must believe that the long labour of 
Science and Philosophy and all the travail of the generations have done something to enrich and widen our thoughts concerning the facts of religion. When we remember what a narrow thing the Universe was in the eyes of the first disciples, when we consider that the future of humanity on this earth was bounded for them by the horizon of one generation, when we note the literalism that seems to have coloured their conceptions of Resurrection and Judgment and the Kingdom of God, we cannot but believe that the content of the Gospel has, in some respects, a wealth of meaning for us which it did not have even for the first great Masters of the Faith. As the common man knows things to-day about the natural world that were hidden from Bacon and Newton, so the religious Democracy now understands and is able to teach aspects of spiritual truth that were not in the mind of John or of Paul.

On the other hand, we may not question the power of the democracy to degrade the Gospel by compromising its ideal, lowering its aim, misinterpreting its purpose. We cannot ignore the witness of History to the decay of faiths, and the slow decline of great enthusiasms, and the degeneration of noble forms. Buddhism, that was meant to be 
spirit and freedom for men, became a law and a tyranny. Mohammedanism, that was at first a warm enthusiasm, was changed to a cold system of fixed observances. The Christian Gospel itself appears to us in history under many strange disguises; now obscured by legalism, coloured by alien elements, corrupted by the world; now debased by superstition and fanaticism; now cold and poor and bare. Always, since time began, the common consciousness has been liable to err and forget, to confound form with substance, to carry conviction to "wasteful and ridiculous excess." The highest things become degraded to the level of lowest need. Customs that were good corrupt the world. The vision fades to the colours of common day. And thus the authority of the Democracy in religion has ever in it an element of danger, a liability to deceive. It needs, therefore, to be always checked and corrected by the direct message of the Aristocrats, and to be tested by the light that lightens every man in Jesus Christ Our Lord.

\section{The Church}

These various characteristics of the common religious conscience must be kept in mind if 
we are to reach a just and balanced view of the Authority of the Church." For the "Holy Catholic Church," the Society of Believers, is the great incarnation of the democratic power in religion. We cannot, indeed, assert that the Church is only the embodiment of the democratic authority, for it is the steward of Revelation and exists by the will, and through the indwelling spirit, of its Lord; neither can we say that it contains within itself the whole of the believing element in Christendom, since there are many devout persons who do not live in its communion. But we can say with assurance that its peculiar weight lies in its expression of the general faith and thought of average Christian people, and we may confidently claim that it is in every age the great organ and interpreter, within Christendom, of the common religious life. Broadly speaking, therefore, we describe the authority of the Church as the power of the corporate Conscience, the witness of "the general" within the realm of faith. "One's belief in the Church as the Organ of religion is to some extent one's belief in the laws of collective

' By 'the Authority of the Church' is meant (in harmony with the whole principle of this Essay) not its executive power or its right to coerce the Conscience, but the constraining weight of its religious Witness. 
psychology, which are the laws of nature, which are the laws of God." 1

\section{Objection to Church Authority}

But this Authority of the Church is undoubtedly a very difficult matter to define and to defend. It is a thing whose very name creates aversion and hostility in many minds, being for them the symbol of tyranny, formality and prejudice. It is often disliked by the student who has learned the vagaries and excesses of ecclesiastical history, who has traced the growth of dogmas, who understands the terror of priestly power and violence. It excites the impatience, also, of the independent thinker who sees and despises the imperfections of the creeds, and finds in tradition no beauty for him to desire. It provokes still more the hatred and derision of the pure individualist and rebel, whose watchword is Freedom and the Future:

"Let the whole past go;

Think God's thoughts before Him." 2

To many devout Protestants, too, and evangelical mystics the Authority of the Church seems something alien and irrelevant. They

1 Tyrrell, Medicualism, p. 146.

2 John Davidson. 
are face to face with their Master as they read the New Testament; they are in the presence of God in the secret hour of prayer. What need have they of any help but faith? What use have they for other treasure than the Spirit? Christ they know, and God they know-but what is this power of the Church?

Ecclesiastical authority is, thus, attacked from many sides, and provokes the resentment of many differing minds. Some are repelled by the Sacraments, some by the forms of worship, and some by the creeds. There are those who dislike the Church on the ground of its political conservatism and 'bourgeois, dull respectability'; while there are others who regard it as a revolutionary force and a serious social danger. Whatever, indeed, you say in its favour is certain to be denied in one quarter or another. If you speak of its right to teach, you are reminded of the confused and contradictory forms of its theology, and asked what you think about Transubstantiation and Eternal Torment and the Athanasian Creed. If you assert that the Church has preserved and transmitted the Gospel, you are shown how the stream of tradition has been coloured by Greek and Roman thought, and distorted by alien political influences. ${ }^{1}$

${ }^{1}$ Cf. Hatch, Hibbert Lectures, p. 49. 
If you insist that, at least, the Christian Society has been the great ethical instructor of the world, you are bidden remember how often it has been the enemy of human freedom and progress and hope. Galileo is mentioned, and the Inquisition and Voltaire, ${ }^{1}$ Mazzini and Garibaldi and Rousseau and Mill and Spencer. It is shown, also, that many great movements, like that for the abolition of slavery, were carried on by heroic individuals in face of the apathy and opposition of the Church. ${ }^{2}$ If, finally, you urge that, in our time at least, the Ecclesia has purged itself of its faults, and is really the teacher and friend of man, you find that in many quarters even this is altogether denied. Individual persons are said to be wiser and more enlightened in spiritual things than the religious Society. It is held that an educated man has nothing to learn from the Church, whose creeds and forms have been outgrown by the enlightened conscience, and that any attempt to assert its Authority is only a presumptuous interfering with the rights of the soul and its direct communion with God. What are Sacraments and common prayer and praise and religious exhortations, to the

${ }^{1}$ See Morley's Voltaire, p. 216 et seq.

${ }^{2}$ Cf. Cotter Morison's Service of Man. 
man who has come to the freedom and power of the enlightened mind and heart?

"What are they all in their high conceit

When man in the bush with God can meet?"

\section{Answer (I) as to Theory}

Now the strength of those who thus deny or depreciate Church authority does not lie in the realm of theory. It is not easy to understand the man who reverences the voice of God in his own conscience and yet is insensible to the majesty of that same voice speaking through the common conscience of the religious Organism. It is difficult to see how any thinker who believes in Revelation can refuse to attribute authority to that Society which exists as a witness to Revelation. Surely it is clear that the very same reasoning which establishes the authority of God in the soul establishes still more the authority of God in the great spiritual fellowship of those to whom $\mathrm{He}$ speaks. It is not possible for the individual Christian to assert his own claims to be a witness to things unseen, and yet refuse profound deference to the testimony of the multitude of his spiritual peers. If there is life in the twig, much more is there life in the tree to which it belongs. If one soldier 
represents power, far more does an army. If the convictions of a solitary thinker are weighty, the same convictions shared by many thinkers are weightier still. And, in like manner, if the spiritual affirmations of one conscience are sacred, more sacred yet are the common confessions of many hearts in many generations.

It is, indeed, said by some that to exalt the Church as compared with the individual, on the ground that the one is greater than the other, is to insist on a difference that signifies little, since Church and individual alike are very small things in the scale of universal being. "The institution is a greater unit than the individual only on a standard of size which, measured even by what we know of the greatness of the universe, leaves neither of them anything." 1 But to speak in this way is surely to overlook the distinction between spiritual and material magnitudes, and is to employ an argument that might easily be used to maintain a complete theological Nihilism. The whole of human history is a very small thing in the life of the universe, less than a grain of sand on the seashore, when valued by a standard of material greatness. But if we adopt a spiritual scale of values, we find no

${ }^{1}$ Oman, Problem of Faith and Freedom, p. 398. 
reason to suppose that the System of things contains so great a thing as Man. It is possible to think of History and of the physical Creation in such a way as to reduce even the life and death of Jesus Christ to a mere inconsiderable episode-His voice but a call in the darkness, His sorrow but a throb of the universal travail. On the other hand, it is possible to think of $\mathrm{Him}$, and his life and death, after a manner which leads us to confess, "Thou art the King of Glory, O Christ." Our judgment as to the value not only of the Church but of Humanity and of Jesus Himself, depends on the standard we adopt. A natural and physical "scale of size" leaves neither man nor Christ "anything"; but a spiritual and moral test leaves man and the Son of Man crowned with beauty and honour. When, therefore, we speak of religious greatness and relative degrees of religious authority, we must be understood to have in our thoughts not material mass and force, but moral and rational power. We would not think of denying that the planet Saturn is "bigger" than Isaiah, or the Pleiades than the Psalms, or the starry host than the multitude of the Redeemed. We are using language that applies only to the things of the spiritual Kingdom, when we say that the 
Soul, or the Church, or Christ, is 'great' and when we discuss the relations of these, the one to the other; and it is not relevant to answer us by an appeal to the tremendous force and mass and glory of Creation. Whatever be the wonder of the Universe, the fine flower of its spiritual essence is still the mind of man; the highest, richest life of that mind, on its religious side, is the Christian Faith; and the fullest expression of that Faith is the Church. And the Church is greater than the individual Christian, as a religious authority, not because it is physically bigger, but because it represents and expresses convictions that have been tested and tried and found good and sure in life after life and age after age. "The authority of the Church is the authority of common consent." 1

But the theoretic authority of the Church rests not merely on the weight of its teaching, but also on the insufficiency of individualism as an account of the religious life. To say that the organ of the spiritual authority is, in an exclusive way, the individual soul in communion with God, would be to ignore the plain facts of experience and thought. There is no such thing as an 'individual' spirit, in the absolute sense. Every self-conscious being 1 Murphy, The Scientific Bases of Faith, p. 180. 
is the sharer in a universal life. He does, indeed, possess something that separates him from his fellows and constitutes the core of his personality; but he has also much which he holds in communion only with all who think and love. The common life of humanity is not only an atmosphere that surrounds him: it is an element that interpenetrates his being -it is the "stuff" that he is "made on." Take away from him all that is not peculiar to himself and proper to his own individuality, and you leave him poor indeed. When, therefore, we speak of 'the soul in communion with God,' we have to beware of conceiving a lonely being, independent and self-sufficient, in solitary fellowship with the Eternal. Such an one does not, and cannot, exist. "The idea of a Christian as an independent, selfsufficing person, capable from the fulness of his own spirit of satisfying all his higher wants, is a mere fiction which all experience belies." ${ }^{1}$ In point of fact no Christian really has, strictly speaking, any "fulness of his own spirit." The environment of his life, the common religious thought of his kindred, the traditional inheritance of faith-without these he has no richness of inward possession. His religious wants and satisfactions alike have been largely created

${ }^{1}$ Moehler, p. 34x. 
by the corporate conscience of his fellows. What would have been the form and content of his worship had he never been taught to pray? What a strange evangel would he draw from the Gospels, with what bewilderment would be read the Epistles, were he asked to study the New Testament without the interpreting light of tradition! No man can say that his prayers are his own, or his confession, or his faith, or his hope. Just as his life is a part of the great human Organism, so his religious knowledge, experience, aspiration and thought, are part of the common religious society in which he lives, and are conditioned and shaped by powers that live and move without his will. Even the most independent and vigorous spirit, if he continues to profess the Christian name, confines his energies to the rejection of certain things in his tradition and the denial of some elements in his inherited creed; he does not set himself to construct a fresh religion of his own. What he has thrown away he inherited; but what he keeps he inherited too. Even Luther and Calvin were at one with their fathers in the thoughts they held of the Divine Nature, the power of Prayer, the authority of the Prophets, the work of Christ, the immortal Hope. And the whole Reformed Church, in its main 
religious affirmations, remains to this day profoundly at one with the Church of Saint Francis and à Kempis. " Protestantism," says the late Master of Balliol, "has to thank the principle of authority against which it protests for all the positive elements of doctrine that still remain to it." 1

It appears, thus, that the power of Tradition, of environment, of the common belief of Christendom, is one of the most formidable of all the facts that confront and challenge the religious thinker. It is based on the constitution of human nature, on the organic unity of the Race. Far from being irrational or transitory, it belongs to the substance of life. To "let the whole past go," or to be independent of surroundings, is the last impossibility. Even to estimate the extent of our debt to inheritance and society is not within the reach of human wisdom. Loisy hardly overstates the case when he says, "We know Christ Himself only by the tradition, across the tradition and in the tradition of the primitive Christians." ${ }^{2}$ Sabatier also, from a very different standpoint, utters the same sense of dependence on the Society: "The Protestant Christian who isolates himself,

1 Evolution of Religion, vol. ii. p. 314.

2 Evangile et $l$ Eglise (Eng. trans.), p. 13. 
believing that he can draw all religious truth from his Bible or his individual inspiration, lives and thinks in unreality." 1 And one of our own theological writers expresses with singular felicity this organic, social aspect of Faith: "The Christian religion in practice is not a Levitical representation of first and second century ideas, but a spontaneous growth which, however nourished and guided by the classical tradition and scriptures of the past, catches its full life from the common fellowship, the mutual enterprise and self-sacrifice which throb within the vital intercourse of contemporary faith." 2

But if all this be true,-if individualism fails to give a complete account of religious facts, and if the relative dependence of the Christian on history and surroundings be allowed,-it is difficult to find a theoretic justification for the refusal to admit the authority of the Church. For the Church, as we have seen, is the great embodiment of the common consciousness in matters of faith, is the steward of tradition, and constitutes the religious environment of each believing life. The man who admits the power of inheritance

${ }^{1}$ Religions of Authority and the Religion of the Spirit, p. 340 .

2 Moffatt, Hibbert Journal, article, "Bookless Religion," Oct. 1908. 
and surroundings and society, and yet rejects the claims of the Church, is as one who should affirm the right of the State and yet deny the authority of Government.

\section{Answer (2) as to Fact}

It may, however, still be said that although the doctrine of Church Authority can be defended in theory, it yet fails when applied to the facts of ecclesiastical history. That history presents to us the picture of a Society which errs and stumbles both in morality and in doctrine, which transfigures the free Gospel into a hard and tyrannous dogma, which, so far from always interpreting the best piety and aspiration of the common religious mind, has often been a mere official and bureaucratic oppression, the enemy of everything fresh and living and generous in the spiritual life of the age. What has been the great foe of scientific Scriptural study? What has most strongly resisted the reformer and prophet? What is it that has regarded with suspicious eye every forward movement in social and scientific thought? These are questions that are put by many people, only that they may be answered with one word, the Church. ${ }^{1}$ And

1 "The clergy" are "not much more than the incarnation of the average darkness of the hour." Morley's Voltaire, p. 229. 
so it is agreed that the organised Christian Society is shown by history to be no true interpreter or organ of the best environment and nobler tradition of faith.

Now, that this general indictment of the Church is to some extent true we may readily admit. No perfection or infallibility can be claimed for it. It is a human organism, and therefore liable to human faults. It embodies largely the thought of the religious democracy, and that democracy has, as we have seen, peculiar tendencies to error. It is the guardian of tradition, and is therefore conservative in habit, as are all stewards of inherited wealth. It expresses the witness of the common Conscience, and the conscience is always liable to aberration and mistake. "In religion as in society," says Hatch, " it is the average that rules " ${ }^{1}$ but the average cannot be expected to equal the prophetic. Even the great Roman apologist admits that "at all times from our Lord and His Apostles downwards, in the midst of whom a Judas was found, there has been much evil in the Church, nay the evil seemed at times to exceed the good." 2 None of us, therefore, need have

1 Influence of Greek Ideas, etc., on the Early Christian Church, p. 34.

${ }^{2}$ Moehler, Symbolism, p. 274. 
any hesitation in making for argument's sake the largest concessions to those who, on different grounds, arraign the historic Society of Christ.

But after all admissions have been made and every reasonable charge allowed, we may still repeat the old confession, "I believe in the Holy Catholic Church." Because it is plain that the same arguments which are used to destroy the authority of the Christian Society might be urged with equal effect against almost every embodiment of spiritual power. Especially could they be used to discredit the witness of the individual conscience itself. Who shall deny that the conscience is liable to error, may be corrupted, can suffer long periods of dulness and blindness? Who shall assert that it has never contradicted itself, never deceived, never believed a lie nor called the darkness light? Every one knows that the witness of conscience varies in form with different ages, in different lands. Did not the Elizabethan Admiral give thanks to God for a weighty cargo of slaves? Did not the moral sense in Torquemada approve the auto-da-fe, and in Calvin sanction the execution of heretics, and in Knox justify religious tyranny? Did not our Lord say that men would often think that in slaying 
His disciples they were doing God service? ${ }^{1}$ What, further, are we to say about the things which the conscience of Plato approved? Truly the individualist who supposes that the conscience in which he trusts is a witness of irreproachable record, is strangely blind to the facts of history and curiously forgetful of the experience of his own life. We believe in conscience as an organ of revelation, because we know that in spite of its failings and weakness it has always and everywhere borne consistent witness that there is a right and a wrong, an ought and an ought-not. We reverence it because, through all its errors and vagaries, it has ever possessed an element undoubtedly divine. Conscience is, in idea and theory, a perfect oracle, but in practice and amid the perplexities of our difficult life it is an authority venerable indeed and sacred, but capable of error and weakness and wrong.

But if we reason thus about the inner witness of the soul, why should we argue otherwise about the common Conscience of Christendom incarnate in the Church? As the individual Christian is liable to error, so is the Society of Christians. As faith suffers

${ }^{1}$ Lord Acton speaks of "the permanent and incurable perversion of the moral sense wrought by a distorted piety." Essay on Massacre of St. Bartholomew. 
eclipse sometimes in the believing spirit, so it is darkened often in the believing Communion. As the moral sense of religious men is often perverted, so not seldom has been perverted the sense of right and duty in the religious Fellowship. As the purest of the Saints have been the children of their age and shown the defects of their generation, so has the Society of Saints in every time reflected the colour and light of its environment. But as the individual conscience, through all weakness and all mistake, has kept undimmed its vision of the majesty of Right and spoken always of a duty to be done and a good to be followed; even so the Church through all its failings and divisions and sins has maintained a constant witness to things unseen, to something better than life and stronger than death, to spiritual need and spiritual food-to faith and prayer and immortal hope. And, therefore, even as we reverence the conscience, so, but with a richer emotion, we reverence the Church.

Harnack, speaking of the state of the Church at the beginning of the third century, says: " Had the Church been asked by way of reproach, 'How could you so forget your beginnings, and to what have you come ?' it might have answered: 'Yes, I have come to 
this; I have been obliged to discard much and to take up much; I have had to fight-my body is full of scars and my clothes are covered with dust; but I have won my battle and built my house; I have beaten back polytheism; I have disabled and almost annihilated that monstrous abortion, political religion; I have resisted the enticements of a subtle religious philosophy, and victoriously encountered it with God, the almighty Creator of all things; lastly, I have reared a great building, a fortress with towers and bulwarks, where I guard my treasure and protect the weak." "1 After the same manner might the Church universal reply to those who to-day impeach its claim to a Divine origin and ministry. It might make answer: "Yes, I have made mistakes; I have often misread the signs of the times; I have suffered disunion, and been conformed to the world; I have not always done justly nor loved mercy ; my faith has been sometimes weak and my light dim. But I have created and preserved the records of the Gospel; I have sought to defend the Evangel from its foes on the right hand and the left; I have kept alive in dark

1 What is Christianity? p. 197. Acton characterised Harnack as "the best ecclesiastical historian now living." Essay on Döllinger. 
times a light of hope and trust, and have compelled the Prince of this world to acknowledge the Kingdom of God. Mine are the Saints and Confessors, the rich traditions of devotion, the temples of perpetual prayer. I have guarded the sacred flame; I have held in my hand the Cross of Christ; and, though my treasure has been in earthen vessels, the excellency of my power has been of God and not of men."

ViII. Church Authority mainly Religious

But if the authority of the Church be admitted, there yet remains the questicnWhat is the nature of that authority? Is it dogmatic or purely religious? Does it extend to the intellectual forms of belief, or only to their spiritual essence? Is a loyal son of the religious Society bound to accept, for instance, the ecclesiastical theory of, Inspiration, Atonement, the Sacraments, the Deity of Christ? Has the Church a right to lay upon the individual conscience the duty of assent to metaphysical creeds-as the Nicene formula, or the Tridentine or Vatican Decrees, or the Westminster Confession of Faith, or the Thirty-nine Articles? Does its authority extend thus far, or is it limited to the sub- 
stance of the Catholic faith-the great universal affirmations of the Christian conscience? To these questions the answer must surely be that the peculiar authority of the Church is mainly religious rather than intellectual, is a matter of faith and not of creed. It is not, indeed, possible to separate altogether the logical from the intuitional elements in religion, or to assert that the devout experience has no dependence on theory. But, while we cannot say that the authority of the Church is $e x$ clusively religious, we may affirm that it is mainly and characteristically so, that its peculiar power belongs to the sphere of the great spiritual assertions which distinguish the Gospel.

We see that this must be the case, when we remember the characteristic function of the Church. That function is to embody and express the common consciousness of Christendom, the generalised experience of the Democracy. The Church is not a prophet or a philosopher; it is a witness to the things most commonly believed in the time that now is and in the ages that are gone. This is the secret of its strength, its special gift and privilege. To every power its talent. As the authority of the separate conscience lies in its individual conviction of 
truth and duty, as the rule of the aristocrat is based on his peculiar experience of a revelation received and a Gospel to be spoken, as the weight of the theologian depends on his learning, his logic, his power to construct rational forms and guard the deposit of faith; so the dominion of the Church lies in its power to express, develop and nourish the corporate religious life. Conscience, Prophet, theologian, Church, alike, are pre-eminent masters only within the special spheres of their endowment. The witness of the ordinary Christian is of little power against the common testimony of believers; the prophet is not of necessity an interpreter of the average religious mind; the theologian has only such influence as his reasoning may command; the Church has no jurisdiction over the prophet. But, if this be true, it is clear that the power of the Christian Society is not, in the first place, dogmatic. It is a matter not of doctrine but of faith, since it is of faith alone that the average mind is a judge. The general consent of Christendom is a stranger to metaphysics, and cannot, therefore, establish metaphysical conclusions. Dogmatic creeds are not the product of the common Conscience-they are the work of experts. It was not the Democracy that constructed the 
Nicene Creed or the Thirty-nine Articles. When we say that these were produced by the Church, we are speaking of the Church as represented by a certain class of educated men who acted under the influence of historical, metaphysical and religious forces-under the power also of party and controversial necessity. Who shall attribute to symbols thus produced the tremendous authority of the general consensus of religious minds in communion with God? That authority, in its fulness, can only be claimed for the spiritual content of dogma-for the substance of the faith which lies within the forms of all the creeds.

It may, indeed, be said that to distinguish between the intellectual forms and the spiritual essence of dogma is a task so hard as to be well-nigh impossible. But is this really so? The apostolic Church held the Lordship of Jesus as a direct religious affirmation-loved and trusted Him, hoped in and prayed to $\mathrm{Him}$-ere ever it had formed a dogma of $\mathrm{His}$ Person. The experience of a special grace in the Sacrament of the Supper belonged to the devout soul from the beginning, and is easily distinguishable from the various theories that have sought to explain it-Roman, Lutheran, Calvinistic, Zwinglian. The elements of the Trinitarian formula were religious experiences 


\section{THE AUTHORITY OF THE CHURCH I 57}

before they became theological statements. The Church itself was a reality before it had ever come to dogmatic self-consciousness, or had "said that "this is I." " The belief in future retribution has had for its concrete form the doctrine of Everlasting Penalty; but the spiritual fact which that doctrine represents is simply the witness of the conscience to a righteous and awful Moral Government, and to the certainty of Judgment to come. ${ }^{1}$ The varying doctrines of Atonement also are but the attempts to utter in rational form the original and unchanging conviction of the Christian mind that "God was in Christ reconciling the world unto Himself." The Calvinistic doctrine of Predestination is only a logical endeavour to express the religious assurance that of God and through $\mathrm{Him}$ and unto $\mathrm{Him}$ are all things. And so generally, it may be shown that the spiritual content of doctrine can be broadly distinguished from its form. Devout conviction was before dogmatic assertion, and continues to maintain a distinct, though not an independent, life. "Devotion and religion existed before theology in the same way that Art existed before Art-criticism, reasoning before logic, speech before

${ }^{1}$ Cf. Martineau, A Study of Religion (Vaticinations of the Conscience). 
Grammar."1 And it is to this abiding and original element of devotion and faith, rather than to the secondary and changing forms of dogma, that the Church bears, in the first place, its reverend witness.

It is important that this distinction between doctrine and faith be emphasised, for if it be forgotten the authority of the Christian Society must be seriously endangered. If we assert that the weight of the Church's witness is first of all dogmatic, we shall rob it of its power. For, as we have seen, the common religious consciousness of which the Ecclesia is the organ is not, can never be, a specialist in theology. The average man of devout life is as far as possible from being an expert in the philosophy of faith. When, therefore, you stake the claims of the Church on the divine rights of its creeds and forms, you are making a demand that has a doubtful basis in theory and a perilous foothold on fact. The religious authority of the Society considered as the embodiment of the common Christian experience is overwhelming; but the intellectual weight of it as it speaks through theological forms is far from being of equal value. To believe in the infallibility of Popes, Bishops, Assemblies or Councils, or Officials of any

1 Tyrrell, Scylla and Charybdis, p. I05. 


\section{THE AUTHORITY OF THE CHURCH I 59}

sort, passes the faith of the modern mind $;^{1}$ and if we insist on identifying the voice of the Church with the voices of ecclesiastics and creed-makers, we shall find it fall on unresponsive ears. But when, on the other hand, we ask men to consider the witness of the Church, maintained through twenty centuries, to God and Christ and Faith and Prayer, and the higher hopes and deeper fears, and the Law that was given in Galilee-when we appeal to them on the ground of the universal testimony of believing souls in all the Christian ages-when we speak of an unbroken tradition of faith handed down from generation to generation, tested and tried by all sorts and conditions of men and amid all changes and chances of mortal life-we are resting the claim of the Church on a reasonable ground of theory and a sure basis of history. "With a little goodwill," and with due Protestant deductions, we may adopt the utterance of a Roman writer: "If faith were theology its problems could never be settled by general consensus. But because it is not theology but the Gospel; because its object is that life of which Christ is the divine revelation and not

1 "Lord Acton distinguished between the authorities and the Authority of the Church." Introduction to Essays on Freedom, p. 27. 
the analysis of that life, any believer may as an expert speak of his own response to the Gospel. Each is a Judge of faith, and the agreement of all is an infallible judgment, eliminating private errors and idiosyncrasies." ${ }^{1}$

\section{Church Authority, in a Secondary Way, Dogmatic}

But to say all this is not to assert that the doctrinal forms of the Church have no authority, or to deny an intimate relation between faith and creed. Although the power of the Confessions depends on the spiritual experience and positive elements of Revelation which they express, yet the expression must be assumed to have a certain fitness and weight. The real is the rational; and faith, if it be other than imagination and dreaming, must be implicit reason. But implicit reason will be ever seeking, by a necessity of its nature, to find coherent utterance in forms of living thought. Hence the stage of reflection and argument which we saw to be part of the prophetic experience; hence the effort which the individual always makes to find a reason for the conviction that is in him; and hence also the continual endeavour of the Church to

${ }^{1}$ Tyrrell, Mediavalism, p. 82. 


\section{THE AUTHORITY OF THE CHURCH I6I}

frame intellectual symbols of belief, and to give to the Gospel dogmatic form. The process by which faith proceeds towards dogma is a natural and necessary one; it is the effort of religion to justify and defend its position in the reasonable order of things, and cannot be checked or forbidden. Belief in God had to become Theism; faith in Jesus had to evolve a Christology; and the immortal hope had to develop a doctrine of Resurrection. When Tennyson speaks of a faith that

$$
\begin{aligned}
& \text { "has centre everywhere, } \\
& \text { Nor cares to fix itself to form," }
\end{aligned}
$$

he is describing something which may exist for a time in the individual life and even in the Society, but which can have no abiding place in either. Faith need not " $f x$ " itself to form ; it may change its expression from age to age; but some kind of reasonable utterance and symbol it must be ever seeking to find. Every devout experience, every direct intuition, has somewhere its fitting and predestined intellectual counterpart; and the work of theology is just the effort to find for each religious element its corresponding rational form. You might as well, therefore, deny the legitimacy of Botany, Astronomy or Physics, as question the place of Theology. 
All the labours of devout thinkers, and all the wars of the Confessions, have meant a seeking after the ideal state wherein piety and thought are one, and "Mind and heart according well" do "make one music."

But if this be so, the Church must have some authority even in matters of creed. There is an organic connection between spirit and form, thought and expression. It is not at haphazard or by chance, but according to definite laws, that religious convictions clothe themselves in certain garments of thought. It is true that "to be visible is not the same as to be vital"; but things that are vital have a way of becoming visible, and the nature of their visible form is not without relation to the kind of their vitality. If a religious experience has expressed itself in a certain dogmatic symbol, and if that symbol has been accepted age after age by believing people as on the whole a true and fitting interpretation, it is difficult to deny some real living harmony between the substance and the form. God does not speak to the religious sense of the individual in such a way that the understanding does not overhear a word He utters. Nor does the Spirit speak in the common consciousness of the Church 
in such a manner that the intelligence of the Church is wholly left without enlightenment. You cannot so separate the soul from the reason, either in the man or in the Society, as to believe that the power of the one shall not lend itself to the other. You may not so exclude the divine guidance from the sphere of intellectual development as to say that the progress of doctrine has had no legitimate relation to the progress of faith. After all, the Church has a mind as well as a heart, and the men who through labour and learning strove to utter its mind were its true and lawful sons. The Theologian comes after the Saint, but he must come; his voice is less weighty than the voice of the Seer, but it must speak - and whoever is under necessity, in the nature of things, to come and to speak, is clearly endowed with power; the creeds are the work of expert, educated men nurtured in Christian tradition, and they have been received by multitudes in many generations as true and helpful expositions. They have therefore at least an $a$-priori right to respectful regard. "Christian thought has been at work for centuries on the object and the experiences of Christian faith, and it would be more than strange if all its toil had been in vain. There is a just and proper jealousy of an 
attitude to the past which virtually denies it the presence and the providence of God, and assumes that where it is concerned we have everything to teach and nothing to learn." 1

When, further, we think, not of the Creeds in general, nor of the body of traditional doctrine, but of the great dogmatic Assertions of the universal Church, we can hardly escape an overawing sense of authority. The doctrines of the Trinity, the Deity of Christ, the Reconciliation through Christ, the Remission of Sins, the Resurrection from the dead, which have been for so many centuries "everywhere at all times and by all men believed," have a peculiar claim to be regarded as intellectual forms in living relation to faith. After we have admitted all that has been said by scholars like Hatch and Harnack as to the influence of Greek thought and other historic powers on the development of the creed, we are still left with the conviction that if the great Catholic affirmations had not been peculiarly fitted to express and defend the substance of faith, they had never survived the stress and strain of all the generations. Greek philosophy, Gnostic speculations, Oriental mysticism, Roman tradition, may all

${ }^{2}$ Denney, Jesus and the Gospel, p. 388. 
have had their part in the shaping of these great dogmatic forms, and yet the forms themselves may be none the less the fittest vessels for the holding of the truth; since Greece and Rome and the Orient, and all their thoughts, had place and part in the unfolding purposes of God. While, once these dogmas had been formed, they continued to live and have their being in the universal conscience of Christendom, not by reason of their historic origin, but because they seemed to the general mind good and acceptable interpretations of the everlasting faith. ${ }^{1}$

The authority of the Church, then, we hold to be first of all and essentially religious, because the peculiarity of the Ecclesia is that it is the organ of the religious Democracy, and the religious Democracy is an expert only in the practical experience of faith. A secondary sanction of a weighty kind, however, must be held to belong to the intellectual forms in which the historic thought of the Church has expressed the essence of belief. Since faith and reason are in close alliance, an intellectual expression must always

${ }^{1}$ Newman tells us that the Bishops "did not play a good part in the troubles consequent upon the Council" of Nicea, "and the laity did. The Catholic people in the length and breadth of Christendom were the obstinate champions of Catholic truth." Arians of Fourth Century, p. 445. 
be held to have some organic relation to the experience it represents. Especially must those dogmas which have part in all the Confessions of all the Churches be held in reverence; as it is inconsistent with a belief in the presence and guidance of God in human things to suppose that true assertions of faith have found through all the ages utterance, which has been persistent and unchanging while at the same time untrue or irrelevant. Yet we can never attribute any finality to any dogma, or limit the right of the reason to continually test, analyse and modify forms of belief. The changeless power of the Christian Society lies in nothing else than its witness to the ever repeated experience of faith in relation to Grod and to Christ and the spiritual communion. The religious life that created doctrine may always transform and renew it ; but the life itself and its witness in the Church is indestructible, the same yesterday, to-day and for ever. Symbols and creeds, however venerable, are but the garments of Faith. They all may wax old as doth a garment, and as a vesture they may be changed. But Faith remains, and its years have no end. ${ }^{1}$

1 We can, of course, see in the history of the Church a process continually going on through which Faith has modified and 
It is true that in all we say of the Church we must ever be open to the charge of idealisation. It is always easy for our critics to show that the Christian Society in practice is other and different from that which we assert it to be. We all "idealise" the Church when we think of it and speak of it with loyalty and reverence - that is, we dismiss from thought and vision certain sordid facts of life and history. But we idealise the Church only as a patriot does his country or a man his mother. The ideal is not untrue; it is in the real and is its life. "Everything must live according to an ideal to which the vulgar reality is not equal; for how else could it be vulgar?" 1 And there is no nobility of thought and life, no possibility of enthusiasm, or of belief in the things that are lovely and of good report, apart from the power to see the divine soul and meaning in imperfect institutions and in sinful men. To perceive this beautiful, eternal element in all the evolution of history and all the concrete facts of life, is the privilege and the duty of those whose thoughts are generous transfigured and destroyed Dogma. And in our own age we witness a profound change taking place in the doctrinal forms of many Catholic convictions-as, e.g., Future Punishment, Atonement, Inspiration.

${ }^{1}$ Moehler, p. 174. 
and true. Even so is it the privilege and duty of the men of good will to ever regard and love the "holy Catholic Church," the Mother of us all- " that vast society to which we belong -that society which for eighteen centuries has gathered into it the holiest and the noblest of our race-that society which links together the ages by the mystic ties of spiritual communion - that society which, though to some men it has seemed a crushing despotism, has been to you and to me and the world at large a beneficence and a salvation." 1

\section{X.}

(a) In reviewing this whole matter one is irresistibly led to the conclusion that modern Protestantism will be constrained for the sake of its own life, to lay greater stress than it now does on the idea of Church authority. This does not mean that any particular form of ecclesiastical government, still less any 'sacerdotal' theory of the ministerial office, needs to be universally asserted or enforced. Every visible community must, indeed, have visible signs and qualities; and it is inconceivable that a Church can exist without the Sacraments, an ordained Order of teachers and officers, and a common confession and ${ }^{1}$ Hatch, Early Christian Churches, p. 24. 


\section{T'HE AU'THORITY OF 'THE CHURCH I 69}

discipline. ${ }^{1}$ But to say that one uniform system of ecclesiastical government must characterise the Christian Society everywhere and in all times, is to deny to the Church that power of adapting itself to environment and circumstance which belongs to every living organism. What is here meant by Church authority is the dependence, both in theory and practice, of the Christian individual on the Christian Society, and the absolute need of Church ministries for the sustaining and culture of the devout life. In this respect the Roman and Anglican positions emphasise a truth which the more purely Protestant communities of Christendom have minimised or lost. "Catholicism," wrote the late Dr. Edward Caird, "has preserved that rich tradition of Christian antiquity which the subjective spirit of Protestantism has tended to cast aside." ${ }^{2}$ And the same great teacher throughout his writing reiterates the conviction that the Reformation, while it gained much, lost something,--that the Roman and Protestant positions represent two sides of the complete truth, and that the one without the other is not made per-

${ }^{1}$ Cf. Lord Acton's Essays on Liberty, p. 193 : "All authority in the Church is delegated."

${ }^{2}$ Evolution of Religion, vol. ii. p. 3 I4. 
fect. Sabatier, also, in spite of his almost extreme antagonism to "religions of authority," often bids us remember that Christianity "can neither realise nor propagate itself without the Church," and that "Protestant individualism too often overlooks the organic bond between the individual and the species, the child and the family, the man and society." ${ }^{1}$ And, in like manner, those Protestant teachers generally, who most clearly discern the signs of the times, are found declaring a conviction that the rights of the common consciousness and the legitimacy of its testimony in tradition must be asserted on a rational basis, if the authority of the Gospel is to be maintained. Nor is the reason of this far to seek. Critical science has made it plain that the Bible, as a solitary isolated Oracle, is incapable of defence.

The power of the Old Testament is seen to lie in its being partly the record of the prophets and partly the confession of that Hebrew religious consciousness in which the Christian tradition has its vital roots. The New Testament, too, is shown to depend for its unique and supreme position, not on any theory of inspiration nor on any rigid view

${ }^{1}$ Religions of Authority, and the Religion of the Spirit, p. 340 . 
of the Canon, but on the fact that it contains three things-(I) all that is historically known of Jesus Christ, (2) the burden of the apostolic teaching, (3) and finally, the witness of the earliest age to its impression of the Master and the Gospel He proclaimed. The right of the Holy Scripture lies, in short, in the incontestable truth that it is "The original source and classic norm of the religious life as it is manifest in the Church itself." ${ }^{1}$ But all this line of argument clearly implies a very lofty view of the corporate Christian conscience, and its organised embodiment in the historic Church. If the witness of that corporate conscience be not in the main to be trusted, then what is the value of its testimony, even as found in the New Testament? If the Gospels contain the impression made by Jesus on the minds of the Twelve and the early Church, then what becomes of our knowledge of Jesus unless these minds are regarded as having been collectively capable of receiving an impression that was true ? ${ }^{1}$ On the other hand, if we know the Evangel only through tradition

${ }^{1}$ Cf. Herrmann, Communion with God, p. 73: "The testimony of the New Testament concerning Jesus arose within His Church, and its exposition is the work of the Church, through the life which that Church develops and gains for itself out of the treasure it possesses." 
and are assured that the Evangel is divine, then we must say of the tradition that it has been a good and faithful steward. We can, in short, commend the Gospel to the individual only on the ground of some theory which shall establish the reasonable authority of that common witness which in the beginning received the Gospel, and has from age to age transmitted it-the Church. And such a theory is found in the view that the ultimate religious oracle must be the Soul in communion with God, and that the great common testimony of this oracle is found in the universal consenting witness of the Christian fellowship, transmitted and repeated from age to age, concerning the things of faith.

(b) But the authority of the Church has to be asserted, not only on theoretic grounds as the witness to the gospel, but because it is the only means of creating and cultivating, in the individual, habits of devotion and exercise of faith. ${ }^{1}$ Men who are not in immediate touch with the realities of common experience, and whose own spiritual life is nurtured by thought and prayer and persistent contact with the great literature of revelation, fail often to realise how dependent the average man is on the teaching and ${ }^{1}$ Cf. Carlyle's Sartor Resartus : 'Church Clothes.' 
worship of the Church. The surroundings of the individual life in our age are intensely secular. Opportunities for thought and study are small. The margin of time and strength left for private devotion is narrow. The tone of general literature is not the tone of the Christian tradition. Homes are busy, and crowded with care. In every way, it is intensely difficult for the ordinary person, in modern life, to keep the light shining in the inner temple, and the fire burning on its altar, and to feel the reality of the life that is in Christ.

"Each day brings its petty dust Our soon-choked souls to fill; And we forget because we must, And not because we will."

The Church, therefore, with its expert teaching, its sacraments and prayers and pastoral encouragement, is supremely important in our day. It brings to bear on the individual life the weight of the common religious society. It helps to form outward customs of devotion which react upon the inner life. By its various ordinances it brings the temporal experience into touch with the eternal. Its ministrations stir up the pure minds of men by way of remembrance. It helps the most careless not altogether to forget-maintaining 
a continually reiterated witness to the things of Revelation. It is, thus, to the men and women of small spiritual power the only direct means of grace; while to the devout and thoughtful it is not less a necessary friend and helper, since religion is ever a social life, and depends for its fulness on communion and fellowship-since

"God's chief seraph waiteth for

A brother's voice to sing."

Protestant thought may fairly adopt the humane and tender teaching of Father Tyrrell as to the ministry of the Church and its value, both as a witness to Revelation, and for its nurture of the devout life, its "hygiene of the soul ";- "Catholicism has learnt to recognise, allow and provide for the non-religious temperament, and for the religious temperament in its non-religious moods, in its states of mere potentiality, in its rudimentary stages of development. It has learnt that though men ought to, men cannot, pray without céasing; that in the best of us the spirit slumbers and sleeps through many of our waking hours; that in most of us its moments of full selfconsciousness are few and far between; and that in the dull intervals we are left to the guidance of habits, formed or deepened in 
those better moments. Catholicism recognises a certain lower goodness in these semiconscious, automatic or merely mechanical species of activity, partly as disposing towards, partly as resulting from, intelligent, self-chosen acts of goodness. When the mind is barren and feeling is dead, mechanical prayers and religious practices are not so merely and utterly mechanical but that they are also exercises and acts of conscience and freewillearnests of 'the better' we fain would offer if we could, in 'the day of small things,' when the flax smoulders without flame, and the bruised reed cannot lift itself upright." 1

This teaching of the excommunicate Roman must appeal to all, whether 'Catholic' or 'Reformed,' who observe the signs of the times, and have concern for the things of the Kingdom of God. It is a witness founded on a true analysis of human nature and a wise sense of its vital needs. The dangers of ecclesiasticism are many indeed and great, but even more to be feared than they are the excesses of an individualistic religion. The individual may find all the freedom he needs within a great Church inspired by the spirit of Christ, but apart from an organised Society of faith individual belief itself must shortly cease

${ }^{1}$ Scylla and Charybdis. 
to be. No man can be said to 'support' the Church; the Church supports the man. We all owe to it more than by our utmost service we can ever hope to repay. The loss of the essential belief in the Ecclesia ${ }^{\mathbf{1}}$-as it has been held in all ages since the time of the apostles-is perhaps the great religious peril of the modern world. Not less for the help of the weak than for the confirming of the strong, for the raising up of the fallen than for the support of those that stand, for the enlightening of our dark hours than for the expression of our better moods-we need the service of the Society of Christ. Men of Catholic mind in all communions will be tolerant of imperfect forms, of historical redundancies, of symbolic excesses, in the Church, if they feel that by these things a real help is given to the simple or the imaginative or the ignorant. They will not be offended by the gnarls and twists on the old tree, if only they are sure that under its branches shelter is found from the fever and from the heat. They will not expect that all men shall limit their creed to the

${ }^{1}$ Cf. Articles of Religion, 19 and 20; Westminster Confession of Faith, 25 ; Tridentine Confession, io and II. See, also, Harnack, Dogmengeschichte (Eng. trans.), vol. vii. pp. 187-189. Also MacPherson's Doctrine of the Church in Scottish Theology. From these we may see how wide is the historic basis of agreement as to the doctrine of the Church. 
things which they themselves believe. They will know, as they consider the facts of life, that the foundations of the Church are the needs of men. They will wish to stablish and strengthen, on a sure basis of living thought, the belief in that Society of which it was witnessed of old that it is the "pillar and ground of the truth," "the Body of Christ," "the fulness of Him that filleth all in all." 


\section{THE AUTHORITY OF JESUS CHRIST, THE LORD}

\section{I.}

The Authority of Christ is either so vast a subject as to be incapable of being so much as spoken about in a short chapter of a short book, or else it is of that even greater magnitude which can be told in simple words and few. Not all the folios of Thomas Aquinas would suffice to contain the discussion before us did that discussion involve New Testament Criticism, the history of the doctrine of Christ's Divinity, the application of the sayings of Jesus to ancient and modern thought and life. And a comprehensive disquisition on the Authority of Jesus, even on the most limited scale, is, clearly, altogether beyond the scope of this essay. But the affirmations of faith as to Christ, in their universal aspects, are of a great simplicity; 
they are independent of all except the most extreme results of criticism; they are interested, but not involved, in the elaborations of Christology; and they are not vitally concerned with particular utterances of our Lord, or the bearing of these upon special problems of life and thought. These great Catholic assertions regarding Christ are that $\mathrm{He}$ is the Object of faith, the visible Appearing of the Divine Life in humanity, the personal Head of the Kingdom, the Saviour and Lover of souls. They are summed up in the saying ascribed to Tennyson, "What the sun is to the flowers, Jesus Christ is to me." Such are the convictions of universal Christianity regarding the authority of our Lord; and it is not inconsistent with the modest purpose of this book to speak of them shortly and simply, seeking only to show that they are in harmony with the line of thought that has been followed throughout our discussion, and are indeed its necessary conclusion and crown.

\section{(1) Witness of New Testament}

Now, we need not labour to prove that the testimony of the general Christian mind regarding Jesus is really what we have said it to be. The witness of the New Testament 
writers as to the primitive faith, so far as it concerns us here, seems to be unmistakable. Professor Denney has done a great service to the Church in his recent book ${ }^{1}$ by showing, on the basis of that which cannot be shaken, what the view of the apostolic community really was regarding Jesus Christ. Those who are not able, through want of time or training, to weigh and estimate for themselves the conclusions of German, French, and English critics ${ }^{2}$ about the New Testament Writings will find in Dr. Denney's book, we believe, a fair and trustworthy judgment as to the broad results of historical science applied to Christian origins ; and if we accept his verdict we find ourselves in possession of documents belonging to the seventh decade of our era ${ }^{3}$ which show that our Lord was then held to be the 'Son of Man' and the 'Son of God,' " not only the Author but the Subject of faith. We are enabled to assume also that the institution of the Lord's Supper, with all that it implies, is securely established on historic ground. 5 And we are assured that the confession of the disciples corresponds

1 Jesus and the Gospel.

2 As the two Weisses, Holtzmann, Harnack, Wernle, Loisy, Bousset, Bruce, Moffatt.

${ }^{3}$ Jesus and the Gospel, pp. 301, 302, 377.

4 Ibid. pp. 55-67.

5 Ibid. 356-366. 
to claims made by Jesus Himself-that our Lord was conscious of an unparalleled relation alike to God and man. Not less impressive is Dr. Denney's exposition of the attitude of St. Paul, and the substantial agreement of the great Apostle with the witness that is contained in the earliest Evangelic documents ? ${ }^{1} \quad$ The general critical conclusions of Dr. Denney's discussion may be taken to establish, on a broad basis, the contention that the earliest Church, responding to the appeal made to its mind by Jesus Himself, gave to $\mathrm{Him}$ "A place all $\mathrm{H}$ is own, a place of absolute significance to which there is no parallel elsewhere," and confessed that "In the relations of God to man everything turned upon Christ and upon faith in Him." 2

\section{(2) Witness of Christian Conscience}

When, further, we leave the New Testament times and proceed to consider the witness of the Christian conscience throughout the ages, we find the same confession consistently maintained. Professor Scott, who holds that the Fourth Gospel was produced in the third decade of the second

1 Jesus and the Gospel, pp. 20-42.

2 Ibid. p. 12. Cf., also, Herrmann, Communion with God (2nd English edition), p. 70 et seq. 
century, discovers in that book a conception of Christ in some respects richer and truer than the view presented by the Synoptists themselves. John, he says, "describes the Saviour not only as $\mathrm{He}$ was within the narrow limits of $\mathrm{His}$ life on earth, but as $\mathrm{He}$ is for ever to those who have known and loved Him." ${ }^{1}$ In this saying, as throughout his beautiful book, Dr. Scott most clearly implies that the Christ who lives in the faith of the Church is more fully and tenderly Lord and Master than was the Jesus who laboured and taught in Galilee-_loved deeplier," if "darklier understood." And certainly the Gospel of John, whatever view we may take of its authorship, wonderfully interprets the Christian mind in its attitude to the Saviour. The Church in all its liturgies and common forms of worship, as in every one of the Catholic creeds, confesses that Jesus is Lord. $\mathrm{He}$ is sometimes made the Object of prayer, and at other times supplications are offered through Him to the Father. Divine honours and powers are ascribed to $\mathrm{Him}$. $\mathrm{He}$ is regarded as ever present with His people and conscious of their wants. The great hymns and sacred songs which, like the Te Deum, have become the accepted expression of

1 Scott's Fourth Gospel, p. 376. 


\section{THE AUTHORITY OF JESUS CHRIST I 83}

Christian praise, have for their burden the tenderness and pity and glory of the Redeemer. The Baptismal formula and the Ascription have no other historical meaning than this-God in Christ and Christ in God. The sign of the Cross is the emblem of Jesus the Saviour. And the Sacrament of the Supper, however interpreted, sets Christ in the heart of devotion and confesses in Him the Bread of Life. The common religious mind holds $\mathrm{Him}$ in all the trust that is due to the Divine; and hands are outstretched to lay hold on $\mathrm{Him}$ as a sure and certain strength. The Church when it looks on the vision of God sees Christ as His excellent glory, and beholds in the midst of the Throne a Lamb that has been slain.

\section{Absoluteness of Jesus}

This is an account of the common Christian view of Jesus which will scarcely be denied historic truthfulness even by those who most utterly dissent from the Catholic tradition. We may think, if we please, that the Church has been, and is, in error, but we may not doubt that this has been, and is, its faith. It is true, indeed, that we must be careful of the term 'absolute' as applied to the place of Jesus in Christian thought and experience. 
We may not fairly use that term in such a sense as to imply that the Christian mind does not distinguish between the Father and the Son, or that it habitually thinks of Jesus as the Creator of the heavens and the earth, or even that it ascribes to Him all the riches of revelation. The Church's thought about Him who lived and was dead and is alive for ever, is quite distinct from its vision of $\mathrm{Him}$ who alone hath immortality; common faith does not associate our Lord with the providential support of the worlds, nor is it of Jesus that it thinks when it says, "The will of God be done." Finally, it would not be fair to say that we owe our whole religious treasure to Christ and to Him alone. The early Christians cannot have supposed that they owed no debt to Psalmist or Prophet, or even to the rich elements of devout thought that were in the common faith of their time. The ancient ways of piety must have been dear to them, as they were to Jesus Himself; they must have known that much of our Lord's teaching had been uttered by the Rabbis. No sense of the wonder and joy of the new Revelation can have blinded their eyes to the olden glories of Hebrew religion, or robbed them of the sense expressed by St. Paul of a tender and filial relation to the sacred and wonderful 
past. In like manner, the Christian Church has never allowed itself to undervalue the treasures of faith that were in the world before the coming of its Lord. It has found its highest expressions of adoration and thanksgiving and the pathos and pity of life in the words of the Hebrew Psalms, and has always acknowledged elements of thought that were the original gift, not of Jesus, but of Isaiah and David and all the prophets and singers of Israel. It is impossible for us to justify on any grounds of theory or experience such an assertion of the 'absoluteness' of Jesus as would involve the undervaluing of the Old Testament, or the denial that Jesus was in some sort not only the Lord but the child of the past. It would be an inexact thing to say that Christ, and Christ alone, is our religion, forgetting that there was a faith in future life, in communion with God, in the tender love of the Father, ere ever Jesus taught in Galilee. There was a society of saints before there was an Apostolic company; there was a fellowship with God before the Mediator appeared; there was trust in forgiving mercy before there was the Cross; there was hope beyond the veil before the Easter morning. When, therefore, we assert that Jesus is 'the absolute' for faith, we do 
not mean to lift $\mathrm{Him}$ out of history nor to deny $\mathrm{His}$ place in a great process of Revelation, nor to disown the right of the mind to reason about His consciousness and to consider His origins. Neither do we say that without Him there would be in the world nothing of light or of hope. What we do mean to say is that Jesus is, for Christian faith, God manifest in the flesh, the final, perfect power of God unto salvation, the ground of the peculiarly Christian assurance of immortality, the Person who conditions all our thoughts respecting the Divine. When we use the Psalms, we use them in the light of Christ; our standard of values when we read the Old Testament is the agreement of its sayings with His spirit. Every one of our religious forms is stamped with $\mathrm{His}$ image. He so informs our inner life that our communion with the Father is through $\mathrm{Him}$. We "mingle all the world with $\mathrm{Him}$ "; and our every impulse of love and of trust is what it is because He lived and died and rose again. Christian faith, in short, "is faith with characteristics and qualities which are somehow due to Christ." 1

Now, when we make the assertion that the common mind of Christendom attributes this

${ }^{1}$ Denney, Jesus and the Gospel, p. 375. 
absoluteness to Jesus, and confesses $\mathrm{Him}$ as Lord, we are on safe and solid ground. Even in the case of those individuals and societies within the Church that have renounced the Catholic forms of doctrine, and refuse in theory to give to Jesus the value of God, we find that there is a real assent to the religious truth that $\mathrm{He}$ is the Master and Centre of faith. Loisy, who has partly justified the action of Rome towards $\mathrm{Him}$ by the desolating extremes of his historical criticism, yet says that Jesus is for faith "King and God to all eternity," and that the worship of Christ is a thing that had to be. Martineau, although he changed so greatly in theological opinion during his long career, ${ }^{2}$ continued always to affirm the central position of Jesus. "The appealing personality of Jesus has been through all distortions the regulative power and the source of unity in Christendom." ${ }^{3}$ "Jesus Christ stands clear of all perishable elements." 4 Bousset, also, who seems to believe that Our Lord expected literally to drink wine new with His disciples in the Kingdom of God,

1 ' Évangile et l'Église (Eng. trans.), p. 125.

${ }^{2}$ Cf. Studies in Christianity, with (successively) Endeavours after the Christian Life, Hours of Thought, The Seat of Authority in Religion.

${ }^{3}$ Seat of Authority, p. 576.

4 Ibid. p. 651 . 
who places Jesus "altogether on the human side of things," ${ }^{1}$ and considers that the last Supper had " not anything to do with Christ's thought of his death" ${ }^{2}$-Bousset has this to say of the Master: "In spite of the separation of time and the frequently exasperating uncertainty of the tradition, we who occupy our place in the history of Jesus through the centuries can still feel his presence near us, with his trust in God, and his nearness to God, his relentless moral earnestness, his conquest of pain, his certainty of the forgiveness of sins and his eternal hope. And when we absorb ourselves in the contemplation of that figure we feel a great uprising of the spirit. For there we touch, indeed, upon the foundations of our own spiritual and personal existence." 3

A singular testimony, surely, to the power of the Christian tradition regarding our Lord, that those who cannot accept some of the elementary parts of the Gospel story, who will not affirm the sinlessness of Jesus, ${ }^{4}$ who conceive $\mathrm{Him}$ as intellectually capable of the most literal and mistaken ideas of $\mathrm{His}$ own kingdom ${ }^{5}$-yet acknowledge that they themselves "occupy a place in his history through the centuries," "can feel his presence near

1 Jesus, p. 84.

4 Ibid. p. 202.

2 Ibid. p. 206.

5 Ibid. p. 96.

${ }^{3}$ Ibid. p. 211. 


\section{THE AUTHORITY OF JESUS CHRIST I 89}

them," can feel that in the contemplation of His figure they "touch upon the foundations of their own spiritual and personal existence." 1

\section{III.}

We assume, then, the substantial truth of the Catholic witness as to the religious Lordship of Jesus; but we are now faced with the question,- - How is this belief in the sovereignty of Christ to be reconciled with the view that the theoretic Organ of authority is the Soul in communion with God? Does such a doctrine of authority imply, or at least allow, the right of Jesus to receive from the individual spirit submission and obedience? This is a question of the utmost importance; for by the answer given to it our theory stands or falls. If an hypothesis fails when tested by its application to the most clear and authentic of all the facts within its viewthen, indeed, it fails utterly and for ever. It lies with us, therefore, now to consider this problem; and we need not be without hope of at least suggesting a positive solution, provided we accept and keep in mind what

${ }^{1}$ Cf. Herrmann, Communion with God, p. 75 : "The question whether the portrait of Jesus belongs to history or fiction is silenced in every one who learns to see it at all, for by its help he first learns to see what is the true reality of personal life." 
has been urged in former chapters as to the authority of the specially endowed individual conscience in the Prophets, and of the common conscience in the Church.

Now, in any complete analysis of the authority of Jesus we must recognise three elements-(I) the perfect form of the prophetic power, (2) Our Lord's own consciousness of Himself, (3) the Church's witness to $\mathrm{Him}$, as Lord. Let us, then, consider these three points, in relation to the theory here maintained.

(I) We find in Jesus the perfect type of the Prophet. Dr. Forrest in his book on the Authority of Christ emphasises this truth as the starting-point of his construction. "Christ as a teacher belongs specifically to the prophetic type. It is not by taking Him out of that category, but by recognising His supreme and solitary position in it, that we shall reach the right conception of $\mathrm{Him}$. . . I I is this which constitutes what we call the authority of Christ, that $\mathrm{He}$ constantly confronts us with an obligation which presses ever down upon us from the Unseen, which will not let us go." 1 The truth that is here so well expressed will, indeed, be challenged by few. The position of Jesus-even His supreme position-in the

\section{Authority of Christ, p. 7.}


prophetic order, is not in real dispute among those who accept the elements of religious history. Mohammed himself saw in Jesus the greatest of the Apostles- "The Word of God" and "one of those who approach near to the presence of God." 1 Among educated Hindus we find a willingness to make the same confession. The position given to Jesus by Keshub Chunder Sen and Mozoomdar - the highest exponents of Indian Theism-is well known and often cited. Even writers distinguished by the distasteful habit of uttering mere eulogies on Jesus, after the fashion of Rousseau and Renan, have no difficulty in admitting that, however deceived or mistaken $\mathrm{He}$ might be, He had in highest measure the prophetic conviction. And the whole of Christendom is united in confessing that, whatever more or higher may be true of Jesus, $\mathrm{He}$ at least had the "sense of being possessed," the consciousness of a revelation received and a gospel to be given-of light shining in $\mathrm{Him}$, and through $\mathrm{Him}$ upon the world-which constitutes the Prophet. We may claim, further, an almost universal agreement that $\mathrm{He}$ had this sense in a perfect way, and was thus the absolute type of the Seer and Saint. Others might have hesitations as ${ }^{1}$ Koran (Sales' edition), p. 36. 
to their gospel; He had none. Others might sometimes speak "as the Scribes," but $\mathrm{He}$ always "with authority." His brethren, before Him and after, might distinguish between themselves and their message; but for Jesus the truth and Himself were in perfect union. The voice of $\mathrm{His}$ own heart and the voice of God were for $\mathrm{Him}$ but one. "To this end was I born, and for this cause came I into the world, that I might bear witness to the truth."

Now, this acceptance of Jesus as the absolute Prophet, and thus the supreme Lord of faith, is entirely consistent with the view that the Organ of Authority is the Soul in communion with God. In Jesus we find the 'absolute historic realisation of such a communion as our theory supposes. That "inspiration of the Almighty which giveth understanding"which is not altogether denied to any, but becomes so great and intense as to be called "Revelation" only in the experience of the Seers and Saints-is in Jesus perfect. Communion is in Him so close as to become identity; devotion to the truth is so complete as to leave no sense of possible separation"I am the Truth." In yielding obedience to Jesus, therefore, we are obeying no external, 
alien power, but one in whom "our own dim life" is come to perfectness. Just as in the prophets we recognise "our elder brothers, but one in blood," even so we confess in Jesus Christ, our Kinsman - Lord. In Him was conscience absolute: how then shall we reverence conscience in ourselves and not worship it in Him?

(2) Jesus' Consciousness of Himself. We should greatly fail were we to limit the kingdom of Jesus to the prophetic sphere, or think of His Lordship as founded only on His witness to certain truths. The prophet is not of necessity aware of himself as possessing any peculiar holiness of character. His mind, indeed, is in harmony with the message he declares, but his will may not attain to the level of his gospel. The very greatness of his evangel may overwhelm him with a sense of personal unworthiness. The thought of the wonderful words he must speak may lead him to say, "I am a man of unclean lips." Mohammed, who believed himself the supreme prophet, made no pretensions to perfect life, confessed sins daily, and died saying, "Forgive, forgive." The Apostle Paul, too, was humbled by the majesty of his own revelation. "To me who am less than the least of all saints," he said, "was this grace given to proclaim the 
unsearchable riches of Christ." He recognised that it was possible for him who had preached to others to be himself castaway. He knew that there was danger of his being "exalted above measure," being betrayed into pride and vainglory, by the very abundance of his visions. And in this matter the Apostle Paul represents, generally, his comrades of the spiritual Aristocracy. ${ }^{1}$ The prophetic consciousness does not involve the sense of holiness; and men may feel themselves the messengers of the Highest, while yet believing themselves unworthy. They may be sure that they are illuminated by the divine light, and yet know that they are out of harmony with the divine will.

(a) But something altogether different must be said about Jesus. He was conscious, not only of being at one with His message, but also of being in perfect harmony with the Giver of $\mathrm{His}$ message. It is too late in the day now to argue that Jesus did not claim to be the Messiah. No doubt Martineau did thus argue $;^{2}$ but his contention was clearly forced upon him by theological necessities. Dr.

${ }^{1}$ Cf. Cairns's Christianity in Modern World, pp. 94-96. For admirable discussion of whole question in relation to Christ, see same book, chap. iii.

2 Seat of Authority, p. 329. 
Bruce, also, seems in his latest writing to suggest some little doubt as to this matter $;^{1}$ but a sentence or two in a short article are not to be held, in his case, as counterbalancing the testimony of a lifetime. And the agreement of scholars, otherwise so divergent, as Bousset, Harnack, Denney, Loisy, ${ }^{2}$ places the matter beyond question. When the most radical, perhaps, of all living critics asserts that Jesus possessed "the consciousness of being the Messiah," and that "there is no reason to question the historical truth of Peter's confession," we may safely conclude that the issue is closed. But if Jesus held Himself to be the Messiah, He must have been conscious of a personal, and not merely a prophetical, union with God. Whatever meaning we may give to the phrases Son of God and Son of Man, and whatever force we may attach to the wonderful "I am" of Jesus, we may be sure that these all signify a peculiar sense of inward power derived from the absolute harmony of His will and heart with the Will and Heart Divine. Messiahship, as mirrored in the mind of Christ, did not mean only the office of messenger, whose life might, or might not, be on a level with his Gospel-not merely the

\footnotetext{
1 Encyclopadia Biblica, article "Jesus."

2 'Evangile et ' E' Eglise (Eng. trans.), p. Ior.
} 
vocation of a king, whose reign might be only in part the reign of God; it meant the nature of a Son whose obedience to the Father was perfect freedom, whose knowledge of the Father was without shadow, whose communion with the Father was broken and defiled by no memory of $\sin$.

\section{(b) Sinlessness of Jesus}

A great deal has been urged against the use of the word 'sinless' as applied to Jesus. ${ }^{1}$ It has been condemned as a purely negative term empty of all positive value; and it has been said to imply an assertion for which there is no sufficient evidence, inasmuch as we know so very little about the life of Christ. But when we use the term 'sinlessness' we are asserting something quite definite; we are employing a word negative in form but positive in substance. We are saying that the consciousness of our Lord was free of that sense of discord with the ideal which characterises the moral sense of us all, especially of the best among us. We are testifying to the "absolute divinity of $\mathrm{His}$ free-will which moulded itself according to the Father's Will without a

${ }^{1}$ For a comprehensive discussion of this subject, see Forrest's Authority of Christ, p. 13 et seq. See also Herrmann's Communion with God, p. 89. 
moment's trembling in the balance " $;^{1}$ we are saying that the humility of Jesus was "the humility, not of conscious unworthiness (like St. Paul's) but of conscious submission, of filial perfection." ${ }^{2}$ We are confessing that the soul of Jesus was in harmony at every point with its true spiritual Environment-God. We are repeating the early conviction of the disciples that $\mathrm{He}$ was tempted in all points like as we are, yet without sin. We are as little guilty of using a negative term when we say that Jesus was 'sinless,' as we are when we say that God is infinite. By 'sinlessness' is meant normal development, harmonious growth, a moral history that carries with it no sense at all of failure or regret.

But, is there a want of evidence for this belief in the sinlessness of Christ? We venture to think that, so far from this being the case, there is no moral conviction more securely founded on reasonable evidence than this. It is freely granted by all, except a few persons of abnormal judgment, that the records contain no fact which can lead us to find any, fault in Jesus, and that they also contain no utterance, or positive suggestion, of penitence,

' R. H. Hutton's Essays Theological and Literary, vol. i. p. 249.

2 Ibid. p. 246. 
contrition or regret. But if Jesus was so good a man as is universally agreed, and was yet one who sinned without confession and transgressed without remorse, $\mathrm{He}$ is the great psychological enigma, the supreme moral puzzle, of the world. When we consider the lives of the saints, and bear in mind the witness of St. Paul, and have in memory the sure fact that growth in goodness always means growth in moral sensitiveness, we feel how perplexing is the opinion which says that Jesus was the best of men, and yet was faulty, and yet was unconscious of defect. The very conception of such an one reduces the moral universe to chaos, and denies the elementary intuitions of the soul. ${ }^{1}$

It may, indeed, be said that our Lord attached no such value to the idea of $\sin$ as do we; that our conceptions of guilt are manufactured and morbid; that to $\mathrm{Him}$, in His glad Sonship, a little error or defect brought no sense of disharmony with God; that $\mathrm{He}$ might have said, in a high spiritual sense, 'What are things like these 'twixt Thee and Me?' It may also be urged that it was in the nature of the Disciples to suppress Lect. 1 .

Cf. Forrest's The Christ of History and of Experience, 
all utterances that implied regret or penitence, and that during the process of idealisation which succeeded the death of Jesus such sayings of $\mathrm{His}$ did of necessity fall out of mind. But, surely, it is to be remembered that Jesus inherited the Hebrew sense of the nature of $\sin$, that $\mathrm{He}$ was bred in the tradition of the Psalms. How can men, especially, who keep repeating with wearisome iteration that $\mathrm{He}$ was the child of $\mathrm{His}$ age and shared its ideas, yet find it reasonable to suggest that in this one matter He held views professed by no religious mind among His people, either before or since His appearing. Evidently the burden of proof lies with those who maintain so amazing a position, rather than with us who believe that $\mathrm{He}$ was at one with all the Prophets in $\mathrm{H}$ is sense of the exceeding sinfulness of sin. Do we not, also, find in His Parables and His predictions of judgment and $\mathrm{His}$ woes uttered against certain forms of evil, most positive witness that $\mathrm{He}$ firmly held the traditional thoughts of historic Revelation as to human guilt and divine holiness? The Church has always believed that $\mathrm{His}$ lament over Jerusalem and the words $\mathrm{He}$ used at the Last Supper, and His anguish in Gethsemane, were all expressions of $\mathrm{His}$ tragic sense of the alienation of men from God; but even if we 
leave these things aside, we may safely maintain that $\mathrm{His}$ Gospel ceases to have any meaning, whenever you cease to assume that there did underlie it a profound pity for every sinful soul and a deep condemnation of conscious and wilful wrong. May it not be urged, also, that we cannot explain the consciousness of guilt which was so strong in the immediate Disciples-which has remained through all Christian history, which is symbolised by the Cross-unless we believe that this consciousness was aroused by Christ Himself? There is nothing vital in the tree that was not in the seed;-how then did there arise the Christian sense of $\sin$, if it did not have its source in the teaching of Jesus and in the experience created by $\mathrm{His}$ touch?

But if Jesus held the Hebrew view of sin, and if $\mathrm{He}$ was Himself a sharer in the transgression of the world, it is not possible to suppose that $\mathrm{He}$ failed to make confession of guilt, or that $\mathrm{His}$ utterances of penitence were forgotten or suppressed by $\mathrm{H}$ is Disciples. If the "contagion of the world's slow stain" had been upon the soul of Christ, how measureless had been $\mathrm{His}$ sorrow. The sense of having disobeyed the Father would have been to Him a haunting weariness. The memory of 
hours of separation from the Highest would have changed $\mathrm{His}$ whole experience and paralysed His power. And the absolute sincerity of $\mathrm{His}$ mind must have inspired such confessions of regret and penitence as ears of men have never heard. "Create in me a clean heart and renew within me a right spirit," cried the Psalmist. "I am a sinful man, O Lord," said Peter. "O wretched man that I am!" was the confession of Paul. "If we say that we have no sin, we deceive ourselves," was the witness of John. The liturgies of the Church have reiterated in all the ages the lament, "Mea culpa, mea culpa, mea maxima culpa!" The utterance of the devout everywhere has been, "All we like sheep have gone astray." But all these confessions and cries had surely been exceeded in bitterness and pathos an hundredfold by the penitential psalm of a sinful Jesus. Great things cannot be, and make no sign. And the fact of guilt in the life of the Christ would have been so great a thing that no power could have kept it secret or enabled it to be forgotten. The memory of the penitence of Jesus must have so burned itself into the minds of the Disciples as to have been a part of all they taught. The words of their Master about His sin would have so sounded 
in their ears as to sound throughout the world.

(c) Whatever, then, may be the theoretical difficulties that beset belief in a sinless Christ, they are not to be compared with the psychological perplexities that surround the conception of Jesus as the best of mortals, who yet sinned without confession, or confessed in such a form that there remains of it no record in history and no echo in the hearts of men.

But the sinlessness of Jesus means His Lordship of the human race in all the things of faith. It constitutes Him the Heir among servants, the Firstborn among sons-the Beloved among all the beloved of God-of all the human Race the One in whom the Father is well pleased. "That absolute union with God, that immanence of the Father in $\mathrm{Him}$, that sense of divine sonship which was the basis of His religious consciousness," ${ }^{1}$ is the basis of Christian faith, the source of Christian history, the power that colours all our thoughts alike of God and man. If Jesus knew Himself one with the Father, He knew Himself also the Master of men. If $\mathrm{He}$ lived on the level of His ideal, His moral history was so different from ours as to constitute a thing of

${ }^{1}$ Sabatier, op. cit. p. 273. 
lonely royalty. "If Christ has lived the perfect life of sonship to God among men, we need ask no more. This fact alone constitutes Him Saviour and Lord. All conceivable saving acts and powers are implicit in it. Let men heap upon $\mathrm{Him}$ all the titles which reverence and adoring love can invent. They can never say of Him anything really greater than that $\mathrm{He}$ realised in our humanity the perfectly God-like life-that in $\mathrm{Him}$ we see Man at one with God." ${ }^{1}$

We find, then, the full Lordship of Jesus to consist in this, that $\mathrm{He}$ was not only the perfect Prophet whose authority is truth, but also the perfect Son whose power is conscious and complete harmony in will and in heartin deed and in thought-with the Father which is in heaven. And in this conclusion we find a further justification of the theory that the ultimate organ of religious authority is the soul in communion with God. Even if we take the highest view of the Person of our Lord-even if we subscribe the Nicene Creed and say that Christ was Very God of Very God and very man of Very Man-we still see in Him nothing else than the blending together of the Divine and the human in one

${ }^{1}$ Stevens, Christian Doctrine of Salvation, p. 366. 
personality. We are still bound, also, to confess that the consciousness of Jesus in the days of His flesh was the consciousness of a man. He did not look out upon the world with the eyes of its Maker. He did not think of men as His creatures, but as His brethren. He did not hold Himself the Object of worship-He prayed to God. $\mathrm{He}$ did not feel ${ }_{i}$ Himself the source of the moral law-He obeyed it. Being our Saviour, He is yet our Kinsman. His rule is that of Lord and yet of Brother still. While we say that His experience was unparalleled, 'unique,' 'absolute,' such as can never be ours; we yet remember that all our language in these high matters is relative and broken; we do not forget that "all intelligences are of one order," 1 -that the spirit of man is of one substance with the Almighty. And so the authority of Jesus at its loftiest remains the authority of the soul in complete and pure communion with the Father.

(3) The Church's Witness to its Lord. We have already seen what the testimony of the Christian Society really is regarding Jesus. It is a testimony that $\mathrm{He}$ is Saviour and King, Son of Man and Son of God. It 1 Channing. 
responds with perfect loyalty to the claims $\mathrm{He}$ made on the Disciples. It reflects as in a mirror His knowledge of Himself as the Brother and the Master of men. From its first utterance in the New Testament to its latest word of prayer and praise-through apostle, preacher, poet, saint and thinkerit has maintained the one consistent religious confession, "I believe in Jesus Christ, God's only Son our Lord."

Now this universal confession regarding Jesus is a part of His authority. You cannot leave it out of sight and yet retain a true conception of $\mathrm{His}$ power in all its richness and mass and glory. To seek to separate Jesus from the tradition $\mathrm{He}$ created, is like seeking to perceive the sun without the sunshine. To distinguish sharply between the Christ of history and the Christ of experience, is just to put asunder what God hath joined together. As we do not see anything except through its atmosphere, so we do not see Jesus except through the medium of historic faith and thought. When we accept the testimony of the Apostle that the Church is the Body of Christ, we remember that the body is dependent on the soul, but also that the soul without the body is not made perfect. It would, indeed, be stating a truth too 
extremely were we to say, with Moehler, that "Christ Himself is only so far an authority as the Church is an authority" $;^{1}$ but it is an elementary act of thought to affirm that the fulness of Jesus is only found in the religious consciousness which $\mathrm{He}$ created, in which $\mathrm{He}$ dwells, its vital spirit. We fail to confess the Lordship of Christ unless we perceive that $\mathrm{He}$ who lived and laboured and died and rose again is the same who is with us alway even unto the end of the world-the Christ who was and is and is to be.' The simple facts of the first Evangelic tradition remain, indeed, indestructible elements of the Gospel; but faith has made of these few things the complex living glory of Christ. "It is the combination of the historical fact in the past with its Divine meaning and relevance in the present, in which the whole weight of the evidence lies; and it is the testimony of believers, speaking in the power of the Spirit, which is used by God to make the historical eternal-that is, to make it living, present, and divinely strong to save." ${ }^{2}$ The Christian consciousness is begun continued and ended in Jesus; but, again, Jesus is Lord for us only in and

1 Symbolism, p. 216.

2 Denney, Jesus and the Gospel, p. 376. 


\section{THE AUTHORITY OF JESUS CHRIST 207}

through that consciousness. $\mathrm{He}$ is the Theme in the age-long music. $\mathrm{He}$ is the determining life in the age-long witness; but we must not divorce the Theme from the Harmony, and we must not dissever the life from its organ. The power of the Resurrection of Jesus lay in its appeal to a faith and love which were created by Him before $\mathrm{He}$ died; if the disciples had not acknowledged $\mathrm{Him}$ Lord before the Cross, His rising again had never made them His. The wonder and joy to them was not that some one rose, but that $\mathrm{He}$ in Whom they trusted rose. And in like manner always; historic facts depend, for their religious value and full reality, on faith; and the secret of the Lordship of Jesus is ever the assent of the soul. ${ }^{1}$

The authority of Jesus Christ the Lord is thus a thing of threefold sanction. It rests on His direct appeal to the mind and conscience, as the perfect prophet and Witness of Truth; on His own certain know ledge of Himself as the sinless Son of God; on the response of that historic religious mind of which $\mathrm{He}$ is the Author, and in

1 Cf. Herrmann, Communion with God, p. 72. Herrmann's peculiar contribution to Ritschlian theology is his teaching that we know Christ only in and through the Church. 
which $\mathrm{He}$ ever lives. These three are separate, and yet they are one. The bond that unites them cannot be broken. The truth that He spoke is truth in Him; the Faith exists because of Jesus; and Jesus is Christ because of faith. Highest prophetic witness, plainest historical evidence, richest religious experience-these all combine together to constitute the Lordship of Christ. How unsearchable, then, is the wealth of this authority; how incalculable is the force of its appeal to the individual mind and heart; with what weight does it "press down upon us from the Unseen." Is it not, in all its elements, most rational and sure? Is it not the final threefold witness of the soul in communion with the Highest?

\section{Dogmatic Symbols}

So far we have been contemplating the Lordship of Jesus on its purely religious side, as a fact of faith rather than of thought ; but this discussion would be incomplete without reference to the dogmatic side of the matter. It is true that in considering the Sovereignty of Jesus from the doctrinal standpoint we shall be compelled to repeat some things that have been said in last chapter 
about the relation of Creed to experience. But reiteration is a less fault than incompleteness.

(I) It may be safely said that the conviction of the Christian conscience as to its Lord will always assume, as it has done in the past, some dogmatic form. However we may seek to distinguish spiritual assurance from intellectual theory, we may not deny the fact to which all history witnesses, that neither the individual Christian nor the religious society can ever be content to rest in a belief about Jesus that has no theological symbol. Devout experience contains in itself "the hidden logic of a Spiritual process," ${ }^{1}$ and the hidden logic will always be striving to make itself plain. In this, as in other matters, there is nothing secret that shall not be revealed. The mind, that is not only pious but active, will always be anxious to find a place for its faith in the order of reasonable things. It will not be satisfied with contemplation and trust; it will want to think and understand. At least it will wish to have something to say in answer to the question, "What do you mean?" It will not continue for ever repeating, "I believe in God through Jesus Christ His only Son, our

${ }^{1}$ Principal Caird, Introduction to the Philosophy of Religion, p. 8. 
Saviour," without asking questions as to the intellectual meaning of 'Son' and 'Lord' and 'Saviour.' And if the answers it gives to these questions may not 'explain' much, they will at least express something. They will express the endeavour to translate the terms of faith into the terms of thought; they will seek to supply forms in which the reason can recognise some true logical relation to the experience of the soul. Fideism ${ }^{1}$ and Modernism, in so far as they seem to imply that revelation can live and exert its power from age to age without finding in the realm of the understanding "a local habitation and a name," are wanting in the only evidence that could support them, namely, historical witness. For, faith subsisting without dogma, except during short periods or in the case of individual lives, simply has never been. The Church has not been in the past, and we may venture to think will not be in the future, a power that asks of men certain confessions and experiences in relation to Christ, and does not, through its recognised teachers and general creeds, seek to supply to its children some theoretical explanation of the things that it requires.

${ }^{1}$ Fideism $=$ French Protestantism minus dogma. Its chief representatives, A. Sabatier, Ménégoz, Jean Réville. 


\section{THE AUTHORITY OF JESUS CHRIST 2 I I}

(2) Now, if we ask ourselves what dogmatic symbol, of all those hitherto created, has on the whole most completely corresponded to the Christian experience of Christ and of God in $\mathrm{Him}$, we may with some confidence assert the claims of the Trinitarian formula to be that symbol. A true analysis of experience will compel the refusal to separate Christ from God; it will also involve the assertion that the Son is not, in the eyes of faith, the Almighty Creator $;^{1}$ and it will imply the confession that there is in the Church's knowledge of the Divine an element that is the consciousness of the Father and of the Son, and yet is more. And the Trinitarian dogma is an attempt to utter in terms of thought this threefold content of religious faith. The doctrine of the Trinity, says Professor Orr, " is in the first instance the result of a simple process of induction from the facts of the Christian revelation." 2 And Pfleiderer, from the standpoint of a pure Theist, makes practically the same assertion. "The interests which determined the lines of the (Nicene) Fathers were undoubtedly first of all religious in their nature, and such as penetrated to the

1.e. Christ does not present Himself in devout experience as Creator-God.

${ }^{2}$ Christian View of God and the World, p. 303. 
very depths of the Christian consciousness." 1 Whatever may have been the influence of Greek thought in giving to the Nicene Creed its special form and metaphysical elaboration, it owes its origin to a genuine witness of the soul, and is an effort to safeguard essential things in our religious heritage. It is at least a comprehensive endeavour to express the whole attitude of the believing spirit towards Him of whom it is testified "that $\mathrm{He}$ is the Brightness of the Father's Glory, and the express Image of His Person." 2

(3) The insufficiency of the dogmatic forms, which are the historic rivals of the Trinitarian solution, appears in their obvious want of power to accept and symbolise the whole content of Christian faith towards God and towards Jesus. The two great historic rivals to the Catholic dogma are commonly associated with the names of Arius and Socinus respectively - though they are both older than their reputed authors, and have probably never been without their adherents in any age of the Church. The Arian doctrine ascribes to Christ a position midway between

1 Pfieiderer, History of Philosophy of Religion, vol. iii. p. 217.

${ }^{2}$ Cf. R. H. Hutton's Essays Theological and Literary, vol. i. chap. viii.; also Maurice's Theological Essays, passim; also Principal John Caird's Gifford Lectures, Lecture on Trinity; also Forrest's The Christ of History, etc., Lect. v. 
God and man-regarding $\mathrm{Him}$ as a being pre-existent, though not eternal, the Creator of the Worlds though not Deity, a demi-God and subordinate Providence. But this is a Creed which "means nothing" as an interpretation of Christian experience. Faith thinks of Jesus as Man and it thinks of Him as God, but never as neither the one nor the other. Men hold $\mathrm{Him}$ to be their human Master, and they find in $\mathrm{Him}$ the presence of the Highest; but according to Arianism he is not Man, nor yet is He the Highest. The condemnation of Arianism, the characteristic which justified the Catholic Church in casting it out, is not merely its metaphysical weakness-though that is very great-but its complete failure to present a view of Jesus corresponding to the content of practical living faith. The puzzle it presents to the understanding is just as difficult as the Athanasian Creed; and it is a purely gratuitous puzzle, for it has no relation to facts. "It is a weary way to God; but a wearier far to any demi-God."

The Socinian, or Unitarian, dogma, on the other hand, does represent and express realities of faith. In teaching the Unity and Transcendence of God, it embodies that sense of the lonely Majesty of the Almighty which is 
deep in the heart of religion and is the secret of adoration and reverence. In asserting the Humanity of Jesus, also, it has truly interpreted the Christian consciousness; for the thought of the Saviour as human Brother and Friend, the Son of Mary, tempted, tried, rejoicing, sorrowing, labouring, dying, is the thought, of all others, which the heart of man will not let go. Dear to that heart is the divinity of Jesus, and dear is His humanity ; but if it had to choose between the two it would keep the humanity. Unitarianism, then, does represent, so far, a true endeavour to symbolise the substance of faith; and in the writings of many of its best teachers, like Martineau, Channing, Freeman Clarke, Beard, John Hamilton Thom, and others, it is shown to be capable of a singularly high and strong and noble type of thought. Its history, too, especially in New England, is rich in the peaceable fruits of righteousness and charity. The Society out of which came Emerson, Longfellow, Lowell, Wendell Holmes, Margaret Fuller, must ever hold a place of love and respect in the Catholic heart of Christendom. Nevertheless, we may venture to think that the Unitarian analysis of Christian experience does err by defect, and leaves an element in the historic faith completely unexpressed. It cannot explain the 
Church's devotion to Christ as God, except as a corruption and superstition. Prayers and praise addressed to Jesus, and the ascription to $\mathrm{Him}$ of Divine honour, which have been part of Christian practice in all the ages, it can only repudiate as little better than the worship of the Saints. The sense of the oneness of Christ with God, and of a personal relation to the Son as the Object of faith and trust, is certainly a part of the Catholic consciousness; but Unitarianism is not able to give to this any theoretic or symbolic expression. The undoubted fact, so strongly emphasised by Ritschl, that Christ has for us 'the value of God,' is not represented in the theology of Channing or of Martineau. Hence it is that we maintain this theology to be an incomplete attempt to express the facts of religion. There has been much Unitarian Christian dogma, but there has been no Unitarian Christian faith. ${ }^{1}$ That is to say, all men who have held the historic attitude of Christian discipleship have had elements in their feelings and desires towards Jesus which the Socinian dogma neither justifies nor explains. ${ }^{2}$

1 Cf. Maurice's Theological Essays, p. 94.

2 See Harnack's History of Dogma: section on the "Socinian Doctrine." Especially the closing estimate of that Doctrine, vol. vii. pp. 165-167. 
(4) And so we return to the point that the Trinitarian formula remains the only comprehensive attempt to represent in the language of thought the whole of the universal believing experience in relation to Christ the LordHis Humanity and Divinity, His oneness with us and with the Father, and His indwelling Spirit in the Church. Every attempt to elaborate the dogma of the Trinity may be faulty-so indeed are all endeavours to state the doctrine of God in relation to man. The Nicene Doctrine may be inconceivable to the understanding -as also is the much lauded dogma of Divine Immanence, as is every theoretical statement of personal Immortality. But, at any rate, the Trinitarian confession seeks to face the facts given in Christian faith from the beginning, and to state them in their fulness, embracing all, denying none. It does not present more difficulty to the reason than does Deism or Pantheism or Unitarianism, while it conserves the Christian belief in God, as transcending all the universe, yet dwelling in the world and in the mind of man. ${ }^{1}$ And, above all, it protects the 'Deposit of Faith,'

${ }^{1}$ It may be fairly maintained that the history of Socinianism has shown generally that, when the Trinitarian Confession has been abandoned, religious thought has shown a tendency to fall into Deism, on the one hand, or Pantheism, on the other. 
and seeks to be true to the realities presented by the religious consciousness and by the mind of Christ.

\section{V.}

We say, then, that faith in Jesus is that spiritual reality which is the essence of our religion; but we believe that the doctrine expressed in the Trinitarian formula, whatever its defects, is the best historical embodiment of the Faith, in the region of thought, and has therefore great, though secondary, sanction. Devotion to Christ dwelt in the disciples at first without dogmatic form when they called Him Son of Man and Son of God, Saviour and Lord and King. That simple personal devotion remains still the soul and substance of Christian life. It, in itself alone, constitutes a Christian. It is the spirit within the letter, and without that spirit the letter profits nothing. It only carries with it the full weight of the authority which belongs to the universal witness of the believing soul. "The qualifications for standing in the line of Christian affiliation are not intellectual but moral and spiritual: and it ought to be impossible to deny the name of Christian to any that acknowledge Christ as their master, and can 
show any genuine likeness to Him." ${ }^{1}$ But since, in the nature of things, faith must become self-conscious and clothe itself in rational forms, and since the form taken by the thought of the Church regarding its Lord has been the Trinitarian doctrine, we are bound to hold that doctrine in high historic reverence. This reverence, further, is deepened by our knowledge that the dogmatic rivals of Trinitarianism have been seriously defective, inasmuch as they have ignored undeniable elements in Christian experience and have failed to commend themselves to the universal Church; while, on the other hand, the belief in the Trinity has represented the living realities of faith, has guarded the peculiar treasures of the Gospel, has endeared itself to all the ages, has been the symbol of God revealed in Christ. And so we of this latter age may honestly and gladly remain in the faith and profession of our fathers. Not attributing to dogma the authority that belongs to faith alone, not seeking to limit the power of development and even revolution which is the privilege of Christian thought, not asserting that the ancient threefold Ascription must be spoken by all who would belong to the Church, we may yet confess that, as for us, we

${ }^{1}$ Beard, Hibbert Lectures, p. 428. 


\section{THE AUTHORITY OF JESUS CHRIST 2 I 9}

remain in the Trinitarian creed, believing it richer and fuller than any other, the completest form of Christian Theism, the truest symbol of the universal faith. It is not only æsthetic emotion, nor purely historic and imaginative feeling, that endears to us the old doxology to the threefold Name. For it is a true voice of the catholic belief, a vital expression of the beautiful and tender witness of faith through all the generations-it is the very burden of our whole tradition-that thrills and sounds through the ancient words, "In the name of the Father and lof the Son and of the Holy Ghost." 
CONCLUDING NOTE

I.

Recapitulation. - Authority in Religion, like every other subject of human thought, has an ultimate-something beyond which neither observation nor reasoning can carry us, something, therefore, that is to be accepted as the starting-point of all theory, the basis of all rational construction. This ultimate is the Communion of the Soul with God. The human personality is to be conceived as capable not only of speaking to the Divine, but also of receiving authentic messages and inspirations from the Father of souls. This capacity is a necessary part of the essential unity of life which must be ideally affirmed to exist between the Infinite Spirit and $\mathrm{His}$ finite children. It is to be said of God that $\mathrm{He}$ is self-conscious ethical existence, and this also is to be said of Man. God and Man are therefore sharers in one life, and com- 
munion between them there absolutely must be. By no theory which admits the spiritual view of the Universe can this really be held in doubt. No religion can question it; for if every man can speak to God, God may speak to every man. The Almighty can and does give directly of $\mathrm{His}$ truth and grace to us, in proportion as we are willing and able to receive. This speaking of God to us we take to be the indisputable fact, which is the common element in all true forms of Authority in Religion.

When we pass from the region of abstract theory to that of experience and observation, we do not find anything to contradict this view as to the Organ of Authority. For conscience in its great affirmations as to Duty and Responsibility-as well as in its universal forebodings and hopes-wears an aspect unmistakably divine; while all true and living faith, in its higher hours, has in it a consciousness of direct relationship to the unseen, an experience of light shining in from without, which, if it be not all delusion, implies the presence of God with the soul.

We do find, however, that, by reason partly of the circumstances of our lives, partly of our 
imperfect development and partly of our positive disobedience, the voice of God is not able to make itself clearly heard in the common spiritual experience of average men. It is not able to utter itself with the wealth and fulness that constitute Revelation. Rather is the immediate presence of God shown to us like rare and fugitive gleams in a dull and cloudy sky. The Divine message sounds in our ears from the transcendent region as broken chords of a far-off harmony, as stray words of a wonderful voice whose burden the tempest carries away.

We are therefore dependent for fulness of light and leading on an Order of Messengers and Prophets through whom the Highest speaks to us, on the Society of believing men and women which hears, interprets, preserves, and applies the Word of Revelation, on One especially who is the Light and Truth and Love of God. Our practical dependence on these-our manifold, immeasurable indebtedness to them for our spiritual treasure-is a thing to which history and thought and our own experience abundantly witness. When we consider how little of the entire sum of our inward possessions can be called the fruit of our own communion with the Highest, when we seek to imagine 
what our state would be apart from the ancient heritage of faith, and apart from the religious Society which is our home, we understand the measure of our subjection to the appointed authorities of the spiritual Order. Of all forms of arrogance there is none that appears to us so futile as the arrogance of a self-dependent piety.

But in thus acknowledging our reasonable subjection to "outward" authorities we are conscious of no humiliation, nor of any unfaithfulness to the inner Witness. For we know that these authorities could have no power over us at all were they not of the same nature as the Oracle that speaks within the soul. The light that shines into our hearts we recognise to be the same that has always dimly burned within. The power of the Church is the kindly power of Home and our own people; the prophets speak the language that is spoken by all the voices of the spirit; and Jesus, being our Master and Lord, is yet the Son of His Father and our Father, His God and our God.

The assertion, then, that communion with God is a possibility, and even in some degree an actuality, for all men, does not involve the rejection, but rather compels the acceptance, of those authorities which we call "out- 
ward" and "objective." For, the acknowledgment of any power in its poorer and narrower forms, involves the fuller acknowledgment of it in those manifestations which are greater and richer. How shall we attribute weight to the limited experience of the individual religious mind and not far more yield homage to the long and wide and varied experience of the common religious mind, as expressed in the Church? How shall I reverence my own intuitions, and not regard with deeper veneration the intuitions of Isaiah or John or Paul? How shall I see in Jesus (at least) a life entirely at one with God, and not accept $\mathrm{His}$ testimony as an immeasurably higher thing than the witness of my poor, groping faith? This is the sure and steadfast ground on which the religious authorities stand, that they rule us by right of the very power that shows itself in conscience, and in the higher moods and deeper emotions of the individual religious life.

\section{II.}

Practical Inferences. From the foregoing theoretical position there follow certain practical inferences as to the relations which ought to exist between the individual man and the great historical Authorities. 
(1) The individual owes as his reasonable service an attitude of reverence towards the proved and tested powers of the spiritual Order. Faithful to the rights of his own personality and the laws of his own nature, he must in the last resort remain, for he can do no other; but he will always proceed, at least, on the conviction that the great religious Masters are not likely to be wrong, or to need correction from him, within the province of their own especial gift. $\mathrm{He}$ will know, for instance, that he is as likely to understand religion better than St. John as he is to understand poetry better than Homer. It cannot, indeed, be theoretically affirmed concerning any man that he may not receive a "special revelation," since all things are possible with God; but the probabilities are overwhelmingly against the bestowal of such a gift, since special revelations are of all things in the universe the most precious and most rare. It cannot be asserted beforehand of any one that he does not belong to the prophetic Order; but the presumption is always against him, since the prophetic Order is the smallest Aristocracy in the world. It is always possible that the experience of an individual as to faith and prayer and the culture of the devout life may 
be richer and higher than that of the great common Fellowship of believers, the ancient universal Church;-it may be, but who shall affirm that it is? An ordinary person may possibly be found who maintains that his relation to God is so direct as to render him independent of Jesus Christ and superior to His authority; but a claim like this can only be silently registered, and left in the hands of Time; it is beyond the region of debate, because it soars above the realms of actuality.

(a) The individual, then, who keeps in view the real source and nature of authority, will maintain the freedom of his soul and hold inviolate the sanctity of his personal faith. But he will approach every matter in which he feels himself at discord with the great religious powers in a spirit of misgiving and self-distrust. If, for instance, he finds himself in doubt as to the efficacy of Intercessory prayer (feeling, as he well may, that no sufficient logical defence of this has ever been produced), he will yet be surely constrained to remain in the ancient belief and practice as to this high matter, when he considers the example of Christ and the Apostles and all the Saints; when he remembers that wherever there has been religion there has 
been also intercession; when he reflects that the offering of prayer for one's fellow-men is so universal a part of devout life that either it is justified or faith itself is vain.

This attitude of reverence towards approved and tried authorities has ever distinguished the greater religious teachers and reformers. With what unwillingness, through what travail of spirit, after how many years of hesitation and doubt, did Luther at last come to break with the ancient tradition, and to buy the freedom of faith at the cost of the unity of the Catholic Church! And even such will surely be the temper of every religious man who understands his debt to the past, his dependence on historic Revelation, his part in the great corporate life of Christendom. A reformer, a rebel, a schismatic, he may become, if so he must; but in his dealings with Scripture, the Church, the sacred Forms of ancient faith, he will be in habit reverent, self-distrustful, slow to dissent, slow to destroy.

(b) But there is also to be considered the case of the individual Christian who is not tempted to rebellion or denial, but is, it may be, in doubt and perplexity because of changing theologies and critical debates. To such an one it often seems as if the authorities in which he has trusted were shaken, as if there 
were nowhere sure and certain ground, as if there were nothing left on which he might with confidence lay his hand-no way of escape from a miserable dependence on the resources of his own unstable faith and doubtful thought. For him there may be rest and peace if he remembers what the true foundation of authority is-that it is the same as the basis of his own personal moral life, the Communion of God with Man. Remembering this, he will never doubt that his bread of life is sure. He will not suppose that the stewardship of the eternal treasure has been given to theologians and experts. He will be delivered from dependence on things that may be shaken, and will find his feet upon a rock. He will not trust to the letter that changes, but to the spirit that abides for ever. The power of the Scriptures, for him, will depend on none of the things at present in debate, but on the record it contains of the authentic Revelation of God in Prophets and Saints and in the consciousness of Jesus Christ. The right of the Church to guide and help and comfort him by word and sacrament, he will feel to rest on no ecclesiastical theory, but on the constitution of human life, on the social character of faith, on the consenting witness of religious 
men in all the generations. Thus, the man who keeps in view the true conception of authority will not be unduly troubled by the battles of the schools, or by the facts that are revealed through historical and critical research. Modifications of dogma, altering forms, increasing knowledge, touch not at all the ancient foundations. Though all things else "are changed by slow degrees," the basis of religious authority, which is the Word of God spoken in the souls of His Messengers, and attested by the continual witness of faith, stands sure.

"The City of God remaineth."

(2) Authority in its relation to the individual must always be modified and restrained by a true conception of its own origin and nature. Evidently, the consciousness that its rights are essentially religious and are founded on a spiritual possession which is in some measure the heritage of every man, will limit the action of Authority, and save it from arbitrary and oppressive exercise of power. The record of authority, as embodied especially in the Church, is a blurred and blemished page. Ecclesiastical power has tended to become external, formal, tyrannous. It has been 
careful and troubled about little things. It has often seemed to prefer outward conformity to intelligent faith and exalted life. In the Roman Church it has countenanced forms like the Inquisition, and has sanctioned strange devices for the enthralment of minds and wills. The Reformation, also, was guilty of a great betrayal when it recognised the secular Prince as supreme in religion, and employed civil penalties and disabilities as spiritual weapons. Protestant communions, too, have shown not seldom a spirit of extreme intolerance towards their individual teachers and members; they have extended their sway beyond the legitimate frontiers of their dominion, and have sought to control metaphysics and to censure science. They have cast out men of unmistakably Christian faith and life, on the ground of small speculative offences; and have practically elevated systems of theology to the level of religious revelations. 'Acts of Uniformity,' 'Solemn Leagues and Covenants,' petty oppressions, obscurantist opposition to new thoughts and discoveries, undue interference with personal liberty-these all stand in the records of history as witnesses to the sins of authority against individual freedom and the sacred rights of faith. 
Would any of these things have been if the Church had kept in mind its origin and the conditions of its power? May it not be safely assumed that the Church of the coming age will know nothing of oppressive acts and statutes or of enforced conformity, little of heresy trials or of precise dogmatic definitions? Its symbols will be used for the help and instruction, not for the oppression, of its children. It will leave metaphysical construction, for the most part, in the hands of systematic theologians; and will confine itself to matters of faith and morals and social righteousness, of worship and of the discipline of the religious life. While maintaining, as it must, a common Confession, it will be careful to respect individual belief. It will remember that its message is of faith to faith. It will be very confident of its right to rule, but will be slow to exercise that right to the coercion of the conscience. Even the excesses of sincere men it will patiently endure, even to the voices of unknown messengers it will lend its ear; being anxious lest it fail of any word that cometh from the mouth of God. It will be confident of its high calling as the Steward of Revelation, and will know that its broad and deep foundation stands 
for ever. But, inasmuch as it has learned that the secret of its own power is found in every faithful soul, and that its safety and health lie in the unfettered action of individual minds, it will seek to develop free personalities in the unity of faith. It will strive to commend itself to every man's conscience in the sight of the Father, and will desire that itself and each of its children may increase together in that vital, immediate knowledge of God and Christ which alone is life eternal. 


\section{INDEX}

(Prepared by J. M. Richardson, B.D.)

'Absoluteness,' see under Jesus. Acton, Lord, 22 (note); I2I (note); on aberration of Conscience, I5O (note); on Authority of Church, I59.

Arianism, 212.

Aristotle, on God in Nature, 105. Arnold, Edwin, II6 (note).

Authority, definition of, $\mathbf{I}, \mathbf{2}$; a fact in thought and life, $2 \mathrm{f}$.; a fact in religion, $(a)$ in theology, $(b)$ in ecclesiastical forms, $(c)$ in individual experience, 4-9; enforced by Jesus, 9 .

raises a twofold question, 23; contradiction between Authority and Freedom $(a)$ ultimately irreducible, 23 ; $(b)$ not confined to religious sphere, and chiefly a conflict of authorities, 24.

The Central Problem, 29 f.; its history, 33-42 ; its present position, 42-55.

Relation to Infallibility, $56 \mathrm{f}$; identification with objective Infallibility impossible and irrelevant, 58-62.

becomes Infallibility in the kingdom of the soul, 62-66.
Authority, Rational Basis of, 69 ; the Source of, 70 ; the Organ of, 72 ; not any one of historical embodiments, nor a consensus of these, 73 ; but the common element in them, 74 ; this found to be the Soul in Communion with God (q.v.), 76.

Speculative strength of Theory, 78.

Objections to Theory, $82 ;(a)$ it denies supernatural, $85,(b)$ involves subjectivism, 87 ; (c) involves individualism, 90.

Theory admits authority of Prophet, Church, and Christ, 91 ; and is confirmed by religious view of Nature, I04.

Degrees of, 98-103.

Outward and Inward, I03.

Of the Prophets-

Divine method aristocratic, I Io; Prophet, the Aristocrat of Faith, 113 ; his authority of varying values, II 5 ; four stages of prophetic experience, I16; Vision the secret of their power, II9; apocalyptic 


element, I22; rationale
of their authority, 126.
(See under Prophet.)
of the Church-
Authority of the corporate
Christian Conscience,
I29; definition of, 135;
Objections to, in theory
and fact, 136; seen to be
(a)religious, $(b)$ dogmatic,
153; Importance of, I68;
Errors of, 230.
(See under Church.)
Of Jesus Christ-

New Testament witness to, I79; witness of the Christian Conscience to, 181; Elements in, (a) prophetic office, 190;

(b) self - consciousness, 193; (c) Confessions of Church, 204.
Relation of His Authority to our theory maintained, I92, 203, 207.
Dogmatic Symbols of, 208.

(See under Jesus Christ.)

Relation of the Individualto, 225.

Value of our theory to the Individual, 228.

Modifying influence of our theory on the exercise of Authority, 229.

Bacon, on miracles, 86.

Beard, Charles, on Christian discipleship, 2 I7.

Bousset, on value of Christ for Faith, 187.

Brooke, Stopford A., 28.
Caird, Dr. E., on Authority and Freedom, 24; 42 (note); I25; on the Protestant debt to Roman Catholicism, I45, 169.

Caird, Dr. John, 209 ; 212 (note). Cairns, Prof. D. S., 194 (note). Calvin, 36 (note); on the "Inner I.ight," 79.

Carlyle, Thomas, 172 (note).

Certainty, in the testimony of the Saints, 62-64.

the prerogative of Faith, 64 . perfected by experience, 66 .

Channing, 204.

Church, authority of, 93. definition of, 129 (note). true standard of magnitude of, I 4 O.

Idealisation of, 167 .

Doctrine in Confessions, I76 (note).

Witness to Jesus, I8I, 204.

(See under Authority.)

Church, Dean, 34 (note).

Clarke, Freeman, 1 I 6 (note).

Clarkson, Thomas, on God in Nature, $108 \mathrm{f}$.

Clough, I4.

Communion with God, testimony to its reality, 79 .

the ultimate of religious authority, 81, 221.

broken and imperfect in most men, 91, 222.

fulness of, in prophets, 92, 1 25, 126.

perfect in Jesus Christ, 204.

(See under Authority.)

Conscience, fallibility of, $57,149$. infallible in Jesus, 58. parallel with Church, 149-151. 
Conscience, divinity of, 150,221 . (See also Authority; Wace.)

Criticism and Authority, 49.

Davidson, John, 136.

Democracy,generallynon-creative, I10, II 3 .

to some extent an organ of Revelation, 13I-I33.

Church, the organ of, 135 .

Denney, Dr., on Dogma, I63 f.; on New Testament witness to Christ, $180,181,186$; on the witness of the Church to Christ, 206.

Dogma, necessity of, I60, 209.

can be distinguished from its religious essence, 156 .

relation to Faith, I62.

has no finality, 166.

Döllinger, on need of the Reformation, 13 (note) ; on Freedom, I9 (note) ; 22 (note); 39 (note).

Dorner, on Certainty, 64 .

Emerson, on Revelation, 89 ; on Nature, I05; on "Great Men," I 12.

Ethnic Religions, Authority in, 5 .

(See Mohammed; Sakya Muni.)

Faith, as trust, 37 .

as the organ of Certainty, 64 .

as experience, 65,66 .

as implicit reason, 160 .

in Jesus, the one essential of Christian religion, 217.

Forrest, Dr. D. W., on the prophetic office of Jesus, 190; 196 (note); 198 (note); 212 (note).
Frank, 8r (note).

Freedom, a parallel fact to Authority in thought, art, life, and religion, I2 ; in individual life and faith, 19; conflict with Authority (q.v.), 23.

Froude, on Freedom, 17.

Gladstone, W. E., on Communion with God, 80.

Green, T. H., 71 (note).

Harnack, A., on Luther, 37 ; 38 (note); 42 (note); I2I (note); on the third century Church, I5If.; 176 (note); 215 (note).

Harris, Prof. Samuel, on Infallibility, 60.

Hatch, Edwin, I37 (note); I48 ; on the Church, 168.

Herrmann, on Communion with God, 79 ; on the Consciousness of Christ, 95; on the testimony of the Church to Jesus, 171 (note); 181 (note); on the Portrait of Jesus, 189 (note); 196 (note) ; 207 (note).

Hutton, R. H., on Protestantism and Roman Catholicism, 45 ; on Sinlessness of Jesus, 196, $197 ; 212$ (note).

Individualism, not involved in our theory, 90.

Insufficiency of, 142.

Infallibility, Roman Catholic and Protestant conception of, 4I, 42 ; Relation to Authority $(q . v), 56$. 
Iverach, Principal, on Authority, 31 ; on Infallibility, 60.

James, William, 124.

Jesus, Authority implied in the teaching of, 9 .

Infallibility of, 58 .

Lordship of, 94 .

'Absoluteness' of, 183.

'Self-consciousness' of, I93 ;

(a) Messiahship, 194; (b)

Sinlessness, 196.

(See under Authority.)

Joan of Arc, testimony of, I 24.

Kempis, Thomas à, on Jesus, 63 ; on Communion with God, 80 .

Knox, 47 .

Lindsay, Principal, on the Reformation, 37 .

Loisy, leader of Modernism, 44 ; on Tradition, 145; on the value of Christ for Faith, 187; on Messiahship, 195.

Luther, on Church Authority, 36 (note); on difficulties of the Reformation, 40 (note); on Communion with God, 79.

Macdonald, Dr. Greville, I6 (note).

Macpherson, John, 176 (note).

Martineau, on the difficulties of Protestant apologetic, 46; on Infallibility, 59 ; on Communion with God, 79; on the Supernatural, 85 ; on Authority, 88 ; on apocalyptic element in Revelation, I24; on the self-evidencing power of Prophecy, 125; 157 (note); on the value of Christ for Faith, 187; his theological development, 187 (note); 194 (note).

Maurice, F. D., on the Prophets, II9; 212 (note); 215 (note). Menzies, Professor A., I 16 (note). Messiahship, see under Jesus.

Milton, on Obedience, I0; 74 (note).

Modernism, its origin, position, and prospects, 43-45.

Moehler, on Infallibility of Church, 5, 42 (note) ; against Individualism, I43; on evil in Church, 148 ; on Idealisation of Church, 167; on Church and Christ, 206.

Moffatt, Dr. James, on social nature of Faith, I 46.

Mohammed, his prophetic experience, I16; on Jesus, 19I ; his consciousness of sin, 193 .

Molinos, quotation from, 63 .

Morison, Cotter, 138 (note).

Morley, John, $13^{8}$ (note); on the clergy, 147 (note).

Murphy, J. J., 6I (note); on Church Authority, I42.

Myers, Frederick, I24 (note).

Nature, religious view of, IO4.

Newman, perplexity of, 14; on Private Judgment, 17, 22 (note), 27, 47; on God and the Soul, 63 ; on Conscience, 80 ; on Christian Democracy, 165 (note).

New Testament, authority of, I70; witness to Jesus, I80. 
Oman, Professor, 22 (note); on the Church and the Individual, I40.

Orr, Professor, on agreement as to basis of religion, 80 ; on the doctrine of the Trinity, 2 II.

Owen, John, on Communion with God, 79.

Paul, on human element in Revelation, 60; Revelation in, I04; his prophetic experience, II 7 ; humbled by the Revelation, 193.

Pfleiderer, on Communion with God, 79 ; on religious origin of the Trinitarian Dogma, 2 II.

Plato, 4 (ncte) ; 74 (note).

Private Judgment, rights of, I7, 2I; largely the right to choose masters, 27 ; excesses of, 47-48.

(See under Newman.)

Prophet, authority of, 90-92 ; Aristocrat of Faith, II I f.; analysis of prophetic experience (see under Authority), II 5 ; Jesus as, 190.

Pythagoras, 74 (note).

Rainy, Principal, on Martineau's Theory, 96.

Reformation, origin of, 34 ; problem of, 35 .

Reformed Church, Authority in, $6,8,37,45 \mathrm{f}$.

Ritschl, 79.

Roman Church, Authority in, 5, $8,34,42-45$.

Ruskin, on Freedom in Art, 15.
Sabatier, A., definition of authority, I ; 38 (note) ; 42 (note) ; on Communion with God, 8I ; against Individualism, 145; on the Church, 170; on religious consciousness of Jesus, 202.

Saint Francis, I3.

Sakya Muni, his prophetic experience, I I6.

Sarolea, Professor, on Modernism, 44.

Scott, Professor E. F., 33 (note); on the witness of Faith to Jesus, I8I.

Scripture, and Criticism, 49-52 ; authority of, 170, 228.

Shakespeare, 74 (note).

Shorthouse, John Henry, on Certainty, 63 .

Sidney, Sir Philip, 63.

Sin, Hebrew sense of, 199. Jesus' view of, 200.

Sinlessness of Jesus, not negative, I96; meaning of, I97.

Soul, discussion of term, 77; definition of, 78 .

Smith, Prof. George A., reference to, on Prophets, II4 (note).

Stanton, V. H., 96 (note).

Stevens, Professor, on Lordship of Jesus, 203.

Tennyson, quoted, $63,125,161$, I79.

Tradition, negative aspect of, I29; positive aspect of, I3I ; power for good and evil, I32.

Trinitarian Formula, religious origin of, $21 \mathrm{I}$; insufficiency of dogmatic rivals to, 212; 
its comprehensiveness, 216; Unitarianism, its strength, 213 ; its authority, 217.

Tyrell, Father, a Modernist leader, 44; on basis of Church authority, I35; on secondary nature of dogma, 157 ; on religious character of Church authority, 159 ; on Church ministries, 174 . its incompleteness as an expression of Christian Faith, 214.

Wace, Dr., Analysis of Conscience, 88.

Watson, Wm., on Submission, 3. Wordsworth, on Nature, 105, 106. 


\section{BY THE REV. DAVID W. FORREST, D.D., EDINBURGH.}

\section{The Authority of Christ. Third Edition. Post 8vo, 6s.}

'A stimulating volume, and one irresistible in its literary charm.'-Daily Chronicle.

'A courageous yet reverent and thoroughly masterly handling of some of the gravest and most vital problems in modern theology. It is written, moreover, in a style distinguished by firmness, sincerity, and restrained eloquence.'-Christian World.

'A valuable contribution to the discussion of an important subject.'-Guardian.

\section{The Christ of History and of Experience. Being the Third}

Series of 'Kerr Lectures.' Sixth Edition. In post 8vo, price 6s.

'This book has now won for itself the position of a standard work on a subject which recent critical and theological investigations have rendered of the first importanco.'-Examiner.

"The profoundest and most powerful study of " the mind of Christ" which it has ever been our good fortune to read. The volume is crowded with profound and wise suggestions. It is one of those rare products of theological learning which will amply repay the most eareful study.'-Methodist Times.

\section{BY PROFESSOR W. N. CLARKE, D.D.}

The Bookman says: 'Dr. Clarke's charm both of thonght and expression secure a welcome for anything he may write.'

\section{The Christian Doctrine of God. New Vol. 'International}

Theological Library.' Post 8vo, price 10s. 6d.

'It is as masterly, as inspiring and helpful a treatise as can be found in the famous series to which it belongs.'-Baptist Times.

\section{An Outline of Christian Theology. Seventeenth Edition. Post 8vo, price 7s. 6d.}

'It is difficult to speak of this book in adequate terms without an appearance of exaggerated praise. . . Here at last the great vital truths of the Christian faith are set along the lines of the highest thought of the liberal, reverent, modern mind, and with consummate skill and fascinating interest. Theology is no doubt the queen of the sciences, but, as usually presented, in somewhat austere, ponderous, antiquated guise, has little human attraction. Here it is quick with human interest, answering to the living thoughts of the living generation.'-Puritan.

\section{The Use of the Scriptures in Theology. Crown 8vo, 4s.}

There is a widespread impression that modern studies upon the Bible tend to dimInish, or even to destroy its value for the purposes of theology and religion. Against this impression three lectures utter a protest and offer reasons. The Bible continues to be the unspeakably precious treasure of Christendom, and will retain its place and power as the manual of Christianity and the book of God for men. But its piace and power must be preserved through perfectly frank recognition of the facts concerning it, and use of it for exactiy what it is.

From the Author's Preface.

\section{What Shall We Think of Christianity? Cr. 8vo, 2s. 6d.}

"Dr. Clarke's "Outline of Chriatian Theology" had a reception rarely accorded to an American book, and the sale is briskly proceeding. The new little book is writton in the same oharming simplicity of langnage, and its thoughts are so great and simple that it is likely to find an equally warm welcome beside its elder brother. There are three chapters: (1) The Christian People; (2) The Christian Doctrine; (3) The Christian Power.'-Expository Times,

Can I Beliexe in God the Father? Crown 8vo, 3s.

-Dr. Olarke has here, as elsowhere, shown himself a manter in the art of popularising Chrietian apologetios.' - Chriatian World. 
'A triumphant and unqualified success. Indispensablo to ministers and Bible students.'-Dr. W. Robertson Nicoll.

\section{NOW COMPLETE IN TWO VOLUMES A DICTIONARY OF CHRIST AND THE GOSPELS.}

\section{Edited by J. HASTINGS, D.D.}

Price per Vol., in cloth binding, 21s. net; in half-morocco, gilt top, 26s. net.

The purpose of this Dictionary is to give an account of everything that relates to Christ-His Person, Life, Work, and Teaching.

It is first of all a preacher's Dictionary. Its authors are preachers as well as scholars.

The articles are all new. Even when their titles are the same as the titles of articles in the 'Dictionary of the Bible,' they are written by new men, and with a new purpose.

The articles are not entirely limited to the Bible, but gather together whatever touches Christ in all the history and experience of the Church.

It is called a Dictionary of Christ and the Gospels, because it includes everything that the Gospels contain, whether directly related to Carist or not. Its range, however, is far greater than that of the Gospels. It seeks to cover all that relates to Christ throughout the Bible and in the life and literature of the world. There are articles on the Patristic estimate of Jesus, the Mediæval estimate, the Reformation and Modern estimates. There are articles on Christ in the Jewish writings and in the Muslim literature. Much attention has been given to modern thought, whether Christian or anti-Christian. Every aspect of modern life, in so far as it touches or is touched by Christ, is described under its proper title.

It will be found that the contents of the Gospels, especially their spiritual contents, have never before been so thoroughly investigated and set forth.

'The preacher's purpose is better served than it has ever been before.'-Times.

'A scholarly production, edited with admirable skill.'-Christian World.

'Valuable for all scholars and students, it should prove invaluable for the preacher. -Methodist Times.

'We know of no book likely to be more helpful to the parochial clergy.'-Guardian.

'Invaluable to preachers and teachers, and ought to be in constant use.'-Churchman. 
Now Ready.

Crown quarto, 1008 Pages, with Four Maps, price 20s. net; or in Half=Leather Binding, 25s. net.

\section{DICTIONARY OF THE BIBLE.}

COMPLETE IN ONE VOLUME.

\section{JAMES HASTINGS, D.D.}

This Dictionary is entirely distinct from the Five-Volume Dictionary.

It is complete in ONE Volume.

The Articles are all new.

It is not based on any other Dictionary, but is a wholly new and original Work.

Every Article is signed by the Author. This is the first time that all the Articies in a single-volume Dictionary of the Bible have been committed to Specialists and bear their signatures, as in the largest Dictionaries.

\section{Prospectus, with Specimen Page and List of Authors, post free on application.}

\section{From Early Press Notices.}

'A very fine achievement, worthy to stand beside his larger Dictionaries, and by far the most scholarly yet produced in one volume in English-speaking countries, perhaps it may be said in the world.'-Christian World.

'A book of sterling merit and striking editorial skill. ... These are but a few names picked at random from a long list of distinguished contributors, but they sufficiently indicate the standard of scholarship reached in this entirely admirable work.' $-P u b$ lisher's Circular.

'To produce in a single volume a Dictionary of the Bible sufficiently ample in its scope and plan, abreast of present scholarship, not too elementary to be of use to students and ministers, and not too technical and scholastic in its method for an ordinary reader is, as will be readily understood, an extremely difficult undertaking. So far as our examination of it has gone, it has been admirably accomplished.'-Methodist Recorder.

'An exceedingly valuable and comprehensive work.'-Record.

'The work is able, scholarly, and of a thoroughly trustworthy kind. The editor has been able to enlist the foremost scholars of our time. We must call attention to the careful and masterly sub-editing. It is as near perfection as is possible for man to attain.'-Aberdeen Free Press.

' Thoroughly abreast of present-day knowledge. For presentation and library purposes the book outstrips all its rivals, and its closely packed pages are a perfect mine for teachers and ministers.' - Sunday School Chronicle.

'No pains have been spared to make the book thoroughly reliable and up to date.'Scotsman. 


\section{The Christian Minister and his Duties. By Rev. J.} Oswald Dykes, D.D., Westminster College, Cambridge. Post 8vo, price 6s. net.

"These counsels are the outcome of ripe experience, and are marked by the insight and sagacity, the broad and fair-minded spirit which won Dr. Dykes such a high reputation.' -London Quarterly Review.

The Background of the Gospels; or, Judaism in the Period between the Old and New Testaments. (The Twentieth Series of the Cunningham Lectures.) By WildiaM. FaIRweather, M.A., D.D., Kirkcaldy. Demy 8vo, 8s. net.

'Dr. Fairweather has made the subject of this volume his own. This thoughtful book is one of the most interesting written upon the important subject with which it deals.'Methodist Recorder.

'It is a valuable book, gathering up in compact form and lucid statement the results of a host of investigators. -Homiletic Review.

'Dr. Fairweather's work is one of sterling value, laying its foundation in a careful and sympathetic analysis of its subject.'-Toronto Mail.

\section{The Religious Teachers of Greece. The Gifford Lectures.} By the late James Adam, M.A., Litt.D.(Camb.), LL.D., Fellow, Lecturer, and Senior Tutor of Emmanuel College, Cambridge. Edited, with a Memoir, by his Wife, AdeLa Marion Adam. Now ready, demy $8 \mathrm{vo}$, price $10 \mathrm{~s} .6 \mathrm{~d}$. net.

Contents :-The Place of Poetry and Philosophy in the Development of Greek Religious Thought-Homer-From Hesiod to Bacchylides-Orphic Religious Ideas-Pindar-Eschylus-Sophocles-From Thales to Xenophanes-Heraclitus-From Parmenides to Anaxagoras-The Age of the Sophists-Euripides -Socrates-Plato: His Cosmological Doctrine, His Elements of Asceticism and Mysticism, His Theory of Education, His Theory of Ideas.

'The work of one of the best Platonic scholare of this generation.'-Church Family Newspaper.

'When so prolific a subject is treated with the exhaustive knowledge and expository skill that Dr. Adam brings to bear, students have opened to them a rare source of mental enrichment. - Christian World.

The Bible of Nature. By J. Arthur Thonson, M.A., Regius Professor of Natural History, University of Aberdeen. Crown $8 \mathrm{vo}$, price $4 \mathrm{~s} .6 \mathrm{~d}$. net.

Summary of Contents :-The Wonder of the World-The History of ThingsOrganisms and their Origin-The Evolution of Organisms-Mian's Place in Nature.

'For such a task as he has here essayed, Professor Thomson is peculiarly fitted alike by his eminent scientific acquirements, his profound sympathy with religious feelings and values, and his gifts as an expositor. The scientific interest is the leading one throughout, but the bearings of scientific truth upon religion are never lost sight of, and the real harmony between Christian theism and the doctrine of evolution is brought out in a most convincing fashion.'-Glasgon Herald.

\section{Outlines of Introduction to the Hebrew Bible. By} Professor A. S. Geden, D.D., Richmond. Post 8vo, 8s. 6d. net.

Summary of Contents :-Language of the Old Testament-The Text of the Old Testament-The Hebrew and Greek Canons of the Old Testament-Later Hebrew Literature-The Versions-The Pentateuch. 


\section{T. \& T. Clakr's Publications.}

\section{'RELIGION IN LITERATURE AND LIFE.'}

The Stoic Creed. By W. L. Davidson, M.A., LL.D., Professor of Logic and Metaphysics in the University of Aberdeen. Post 8 ro, 4s. 6d. net.

'These chapters are a contribution towards the exposition and just appreciation of Stoicism. The subject has perennial fascination. As an important stage in the morals of philosophical thought, and as a luminous chapter in the history of natural theology, it solicits our attention, and will repay our study.'-From the Author's PreFacr.

The Religious Controversies of Scotland. By Rev. Henrt F. Henderson, M.A., Dundee. Post 8vo, price 4s. 6d. net. Contents :-Prof. Simson's Affair-The Marrow Men-Hume's Essay on Miracles - The Playhouse Battle-An Ayrshire New Light-The Apocrypha Controversy -Edward Irving-The Row Heresy-The Rise of Morisonianism-The Seoteh Sermons-Robertson Smith and the Higher Criticism-The Dods-Bruce Case.

- Wo can remember no book devoted to the topic which Mr. Henderson handles with such ease and power. It has been read by us with genuine enjoyment and appreoiation.'-Principal Patrick, D.D.

The New Reformation. Recent Evangelical Movements in the

Roman Catholic Church. By Rev. JoHN A. BaIN, M.A. In post 8vo, Second Edition, revised and enlarged, price 4s. 6d. net.

'A remarkable book. It should be read even by those who usually look at no print but what they find in the newspapers. It discloses a state of matters in the present world in which wo live which few have any idea of, and which it concern everyone to know.'-British Weekly.

\section{THE SCHOLAR AS PREACHER.}

These volumes are carefully chosen. They are chosen because their authors are scholars as well as preachers, for the suggestiveness of their thought, and bscause they are saturated with the most promising ideas of the present day.

The Eye for Spiritual Things. By H. M. Gwatkin, D.D., Cambridge. Post 8vo, price 4s. 6d. net.

Bread and Salt from the Word of God. In Sixteen Sermons. By Professor THEODor $Z_{\triangle \mathrm{BN}}$, University of Erlangen. Post 8vo, price 4s. 6d. net.

Faith and Knowledge. By Professor W. R. Ivar, D.D., Cambridge. Second Edition. Post 8vo, 4s. 6d. net.

'The volume is one which is likely to be especially helpful to preachers, 28 giving them fresh materials for thought.'-Guardian.

Christus in Ecclesia. By the Rev. Hastings Rashdall, D.C.L., New College, Oxford. Now ready, post 8vo, 4s. 6 d. net.

'A book which should provs vory useful to tho enquiring student.'Oxford Review.

Jesus Christ the Son of God. Sermons and Interpretations. By W. M. MACGREGOR, D.D., Edinburgh. Post 8 vo, 4s. 6d. net.

'A volume which strikes a distinct note of its own, and contains some of the freshest, strongest, and most human work which one has met with for many a day in the pulpit literature of Scotland.'-Ehlinburgh Evening News. 
Jesus and Nicodemus. A Study in Spiritual Life. By the

Rev. JoHs ReID, M.A., Inverness. Post 8vo, 4s. 6d. net.

'A very thoughtful and suggestive study of one of the most interesting and important episodes in the Life of Jesus.'-Scotsman.

The Christian Doctrine of Immortality. By the late Rev. S. D. F. S SLMoNd, D.D., Principal, and Professor of Systematic Theology, United Free Church College, Aberdeen. Fifth Edition, Revised throughout. Post 8vo, 9s.

'Dr. Balmond's "Christian Doctrine of Immortality" is an able, truth-loving, and, from many points of viow, comprehoneive work.'-W. E. Graderorn.

"This is beyond all doubt the one book on the transoondent subject of which it treate. There is none like it-sound, frank, fearloss, and jet modest in evory page.' -Methodist Times.

The Sacraments in the Nex Testament. By Rev. J. C. LAMBERT, D.D. 8vo, price 10s. 6d.

- Will, without doubt, come to bo regarded as a classic work upon the Sacraments. ... We shonld like to see it placed in the list of books recommended to probationers for tho ministry, and if laymon could also bo induced to read it, so much the better.'Methodist Times.

The Essence of Christianity: A Study in the History of Definition. By Professor W. Adams Brown, Ph.D., D.D., Union Theological Seminary, New York. Post 8vo, 6s. net.

'A remarkable book. It is remarkable for its thoroughness and its lucidity. The subject is one of urgent importance. Dr. Brown sees that the very exiatence of Christianity depends on an understanding - and a reliable understanding - of its essence. And ho has given himself to this difficult task without reserve. . . There is no book of recent issue in America that is more likely to appeal to the English student.'-Dr. HAstrves in the Expository Times.

The Life Everlasting: Studies in the Subject of the Future. By David Purvers, D.D., Belfast. Crown 8vo, price 4s. net.

Prizc. Marcus Dods writes: 'I have read Dr. Purres' " The Life Everlasting " with great satisfaction, and mean to read it a second time. At the present time there is considerable interest in immortality, and I know of no treatment of the subject at once so full and so compact, so woll informod and so temperate, sane and convinoing.'

St. Paul's Epistles to Colossæ and Laodicea. The Epistle to the Colossians viewed in relation to the Epistle to the Ephesians. By Rev. John Rutherrurd, B.D., Renfrew. Demy $8 \mathrm{ro}$, price $6 \mathrm{~s}$. net.

'Exceptionally rich in promise as well as in performance, and will unquestionably take high rank.'-Baptist Times.

To Christ Through Criticism. By Richard W. Sfaver, M.A., B.D., Belfast. In post 8vo (212 pages), price 3s. 6d. net.

'The work of a scholarly, thoughtful, and broad-minded man. Pleasant to read, simple, and judicious.'-Church Family Nenospaper. 

$=\left\{\begin{array}{l}1 \\ \infty\end{array}\right\}$ 


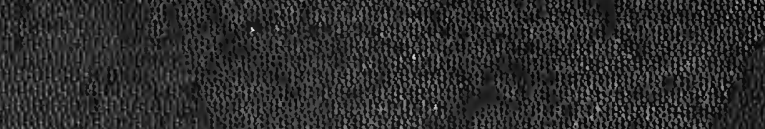

